\title{
A Hybrid Approach to Urban (re)Development in Shanghai
}

\author{
BY \\ WENJI MIAO
}

A thesis submitted to the Faculty of Graduate and Postdoctoral Affairs in partial fulfillment of the requirements for the degree of

\author{
Master of Architecture \\ in \\ M.Arch Professional
}

Carleton University

Ottawa, Ontario, Canada

(c) 2014

Wenji Miao 


\section{ABSTRACT}

Shanghai, China's largest city, is an international business hub with a population of 23.5 million. Much of the city has been ripped down and rebuilt in the past several decades to accommodate its rapid growth. Among the many structures to disappear were factory buildings along the Suzhou Creek, the city's traditional industrial corridor. Despite the radical changes in built form, however, many of Shanghai's urban patterns have remained intact. Of particular interest are the large parcels into which the city is divided and the tendency to organize housing into gated, inwardly-focused enclaves. These enclaves have survived the transition from low- to high-rise, i.e., from dense warrens of alleyway housing (lilongs) to collections of soaring condo towers.

The thesis presents the opportunity to rethink approaches to large-parcel redevelopment in Shanghai. At issue is not only the mixing of uses (in particular office and residential) but the integration of existing and new buildings. These topics are explored through a proposal for the redevelopment of an abandoned, 20-acre industrial site along the Suzhou Creek. Using design as a form of research, the thesis proposes a new, integrated approach to redevelopment - one that embraces density while honoring the city's vanishing industrial heritage. 


\section{ACKNOWLEDGEMENT}

Foremost, I would like to thank for my parents Zhang, xing and Miao,yunjie at the first place, for giving me birth and supporting me throughout my life. For all the things you have been done for the past 24 years, words cannot express how grateful I am.

Besides my parents, I would like to express my sincere gratitude to my thesis supervisor Benjamin Gianni for your patience, motivation and immense knowledge. You have been a tremendous mentor for me, your advice on both research as well as design have been priceless. Especially for editing, I know you have been put a lot of time and energy into it and I truly appreciated.

Lastly, to the people who helped and contributed, this thesis would not be possible without you. 


\section{Table of Contents}

INTRODUCTION

CHAPTER ONE: Historical Introduction to the City of Shanghai

$\begin{array}{ll}\text { Chapter Introduction } & 8\end{array}$

Shanghai in the $19^{\text {th }}$ Century $\quad 8$

Shanghai in the 20 $0^{\text {th }}$ Century 14

Shanghai in the $21^{\text {th }}$ Century $\quad 25$

Chapter Conclusion 31

CHAPTER TWO: The Different Approaches of Mix Use in Shanghai

Chapter Introduction 36

Category 1: Mixed- Use at the Scale of the Building 44

Category 2: Mixed-Use Blocks / Neighborhood Redevelopment 51

Category 3: Mixed-Use at the Scale of the District $\quad 60$

The "problematic" of Different Approaches $\quad 62$

$\begin{array}{ll}\text { Chapter Conclusion } & 63\end{array}$

CHAPTER THREE: Design Proposal

Chapter Introduction 67

$\begin{array}{ll}\text { Site Analysis } & 67\end{array}$

Six Experimental Design Proposals 88

Final Design Approach 99



$\begin{array}{ll}\text { CONCLUSION } & 124\end{array}$

$\begin{array}{ll}\text { APPENDIX } & 132\end{array}$

LIST OF FIGURES $\quad 148$

BIBLIOGRAPHY 155 
INTRODUCTION 
The thesis explores recent approaches to urban development in China through a proposal for the redevelopment of an abandoned industrial site in Shanghai. Like other cities in Reform-Era China, Shanghai has transformed rapidly in the past quarter century. Some 3000 towers of thirty or more stories have been constructed in this period and close to 80,000 residents are displaced each year to address substandard housing, upgrade infrastructure, and accommodate office space for the city's expanding white-collar work force. Assessing what to tear down, what to leave, what to build and where, what form it should take and how to pay for it are pressing issues in Chinese cities. Similarly, extensive thought, planning and economic resources must brought to bear on determining where to locate infrastructure and how to position development relative to it. In addition to the numerous elevated highways that now thread through the city, Shanghai has constructed the world's largest subway system $(538 \mathrm{~km}$. of track, comprising 17 lines and 329 different stations) in just over two decades.

The 20-acre parcel at the focus of this investigation is the former site of the "Shanghai Number One Textile Factory." It is located on the south bank of the Suzhou River, immediately west of the Inner Ring Elevated Rd. Despite sitting vacant for many years, 
many of the buildings within the walled compound are still standing. Constructed of concrete, most appear to date to the 1930s (or to the immediate post-war period).

Land-use maps indicate that the site has been designated as parkland and that none of the buildings will remain. Given the value and paucity of developable land in central Shanghai, however, it seems unlikely that the site would be limited to parkland - especially given its proximity to Zhongshan and Changfeng Parks. Indeed construction recently began on a new building on the southern portion of the site.

The proposed redevelopment of the site incorporates five uses: office, commercial/retail, residential, recreational and institutional. While an overall plan for the site has been formulated, more detailed design consideration has been given to the office component. As an intern at the Shanghai office of Gensler \& Associates in the summer of 2013, I spent much of my time assessing the advantages and limitations of tall office towers. This experience ignited my interest in alternative approaches to office space, specifically mixed-use buildings and districts. Moreover, as the large, open floor plates of several of the existing factory buildings could be readily adapted to office uses, the 
selected site presented the opportunity to the explore the mixing new and old buildings in addition to as the integration of uses. This was of particular interest to me (although not the primary focus of the thesis) given how much of Shanghai's residential and industrial heritage has been razed to make way for high-rises.

Where preservation/adaptive reuse is concerned, industrial buildings have frequently been taken out of the marketplace by being converted into subsidized cultural centers and "creative industry parks." Shanghai's M-50 complex and Beijing's 798 Arts District are well known examples. The conversion of loft-style industrial buildings to conventional office space, however, not only preserves the city's industrial heritage but makes adaptive reuse more commercially viable.

Development (and redevelopment) in Shanghai typically occurs at the scale of the block. Entire blocks, which are quite large by North American and European standards, are frequently (re)developed by a single developer for a single use. This is especially true where residential development is concerned. While uses in Shanghai are often mixed at the small and large scale - i.e., at the scale of the building and that of the district - it is less common for them to be 
mixed at the scale of the block. Similarly, with a few notable exceptions (e.g., Sinan Mansions), it is also uncommon for new and existing buildings to be integrated in the same redevelopment.

Informed by the choice of site and a survey of precedents, this thesis explores the mixing of uses in tandem with the integration of new and existing buildings - with the goal of proposing a new, hybrid approach to redevelopment in Chinese cities. The goal is to respect Shanghai's architectural and urban heritage while taking account of the complex logistical, demographic and economic forces at play in the city's rapid transformation.

\section{Structure of the Thesis}

The thesis consists of a written document and a series of diagrams, drawings and images. The written portion is divided into three primary chapters. The first chapter outlines a brief history of Shanghai to place ReformEra redevelopment in a broader context. Chapter 2 presents an analysis of precedents, namely seven examples of mixed-use development at a variety of scales. It is in relation to these precedents that the terms of reference for the redevelopment proposal were formulated. Chapter 3 provides a detailed 
description of the site, program, and design proposal.

\section{Research Methods}

Research for this thesis took three inter-related forms. Firstly, a review of literature was undertaken to understand the basic terms of reference for Reform-Era development in Shanghai, as well as the circumstances and variations in which uses are mixed. Secondly, thorough documentation and analysis of the site was undertaken by way of identifying potentials and limitations. This included numerous site visits and extensive photographic documentation. Finally, design itself was employed as a form of research. An iterative design process was deployed to define the program and assess various organizational strategies. The design proposition, then, is not only the result of research but was itself a form of research. In this regard the design component of this thesis should not be interpreted as a definitive solution to a fixed set of issues and programmatic requirements. Rather, it is proffered of one of a number of possible scenarios for the redevelopment of the site.

Stated otherwise, the redevelopment proposal for the Shanghai Number One Textile Factory site should be interpreted as a means to an end, namely, a 
mechanism by which an aspiring design professional identifies, explores and assesses issues, analytical methods and various combinations of program and built form in relation to a specific site. 
CHAPTER ONE: Historical Introduction to the City of Shanghai 


\section{Introduction}

This chapter presents a brief survey of the history of Shanghai, identifying types and forms of development associated with various eras. As this thesis proposes to explore new approaches to urban (re)development in Shanghai, it was important to understand basic issues related to land regulation, geographical features, urban and architectural typologies, and the policies employed to address both rapid urbanization and the transition to a free-market economy. A basic understanding of Shanghai's urban and industrial heritage is also crucial to the goal of building upon it.

\section{Shanghai in the $19^{\text {th }}$ Century}

With a population of 23.5 million, Shanghai is China's largest city. As an international metropolis and the country's busiest commercial port, Shanghai contributes significantly to the nation's economy, culture and global reputation.

Shanghai comprises an area of $6,340 \mathrm{~km}^{2}$, consisting of eighteen districts and one county. ${ }^{1}$ Where its urban structure is concerned, streets are roughly laid out to correspond to the curve of the Huangpu River, which forms the traditional eastern edge of the city. The 
older areas west of the Huangpu are known as Puxi or "west river," while the newly developed districts east of the river are referred to as Pudong, or "east river." 2 The Huangpu joins the Yangtze River about 25 kilometers north of Shanghai, immediately west of where the Yangtze meets the East China Sea. Suzhou Creek (a.k.a. the Wusong River) also runs east/west through central Shanghai, forming the northern edge of the city's Central Business District.

Unlike many Chinese cities, which are organized as strict north/south grids, Shanghai developed organically. In the $19^{\text {th }}$ century the established walled city was complemented by various neighborhoods or "concessions" managed by foreign trading partners. Generally the city is organized along the waterways that have made it so favorable as a manufacturing center and port.

While it is virtually impossible to determine the exact date when Shanghai was founded, the city is mentioned in a history written 2150 years ago. Its archaic name was "Hu," referring to the ancient fishing stakes that characterized its status as a fishing village. Due to Shanghai's exceptional location, however, the village was fated to become a commercial port with the rise of global shipping. In A.D 1280, the city was 
renamed "Shanghai," meaning "Upper Sea." 3

Shanghai transformed significantly during the Qing Dynasty. While the first attempt to open trade with China through a sea route was made by an East India Company ship in 1832 , the ship was denied entry into the harbor. Given the nation's policy of isolation and protection at the time, sea-going trade with China proved both difficult and contentious. After ten years, however, and largely due to the first Opium War (1839-42), the British forced the Chinese government to sign the "Treaty of Nanjing" on August 29th 1842. One of the provisions of the treaty was that the cities of Canton, Amoy, Foochow, Ningbo and Shanghai had to open for foreign trade. This provision opened a new chapter in the history of Shanghai, the so-called "Treaty Port" era. ${ }^{4}$

\section{Foreign Settlement}

Although the "Treaty of Nanjing" made no specific mention of foreign settlements, it was expedient for the British to establish them to accommodate the increasing number of merchants and their families settling in the Treaty Ports. The foreigners wanted control over their neighborhoods (institutions, etc.) while the Chinese government wished to minimize 
contact between foreigners and native Chinese. Following treaties with the American, French, and Russian governments during the $2^{\text {nd }}$ Opium War (185660), French and American merchants established settlements (or "concessions") in Shanghai alongside the British. The presence of these foreigners greatly

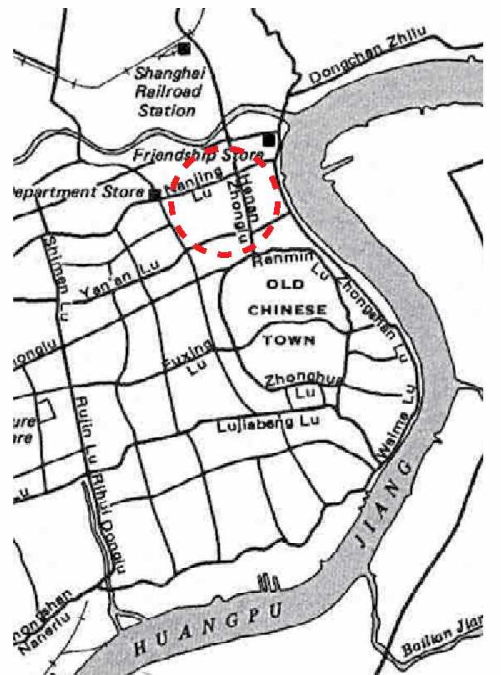

Fig 1.1 British Settlement in Shanghai

affected the form and land-use patterns in Shanghai.

The British settlement in Shanghai was bounded to the east by the Huangpu River and by the Wusong to the north. The southern boundary was defined by Yangjing bang, a small creek, and the west by a ditch that later acted as a defensive boundary. Although quite large, the concession was quickly occupied by merchants and their families. As author Linda Cooke Johnson notes in Shanghai: From Market Town to Treaty Port:

"First a down payment was made to the proprietor; then, in addition, an annual land tax, called "rent," was owed to the government. The British became in effect topsoil occupants of the land, obtaining longterm leases from the various proprietors, who retained subsoil privileges, as was customary in the Jiangnan area." 5

While the British merchants initially tried to negotiate 
with the Chinese intendants directly, language differences made this impossible. For this reason a "consul" was formulated to function as an intermediary between the British merchants and Chinese officials. The consul was, in effect, an agent of the Chinese government in matters arising between foreigners and land proprietors. According to the "land regulations" of 1845

"Once the lots and roads were marked out and lots measured, the merchant aspiring to acquire land made application to the consul, who then consulted with the intendant. If approved, the applicant put down 1,500 cash per mu ${ }^{6}$ as a deposit and advanced the "rent" (actually the land tax) for the lease. The merchant might cease to rent the land, reclaiming the deposit, but the owners could not cease to rent to him at their pleasure or increase the rent." 7

Despite the favorable terms of the lease, the Chinese government retained sovereign rights to the land. Under the settlement laws, annual property taxes were paid to the government by the renter, rather than the Chinese landlords, who themselves were renters. Moreover, the foreigners also took responsibility for the infrastructure within the Settlement, including jetties, roads, street lamps, etc. 
Settlement design generally employed traditional European concepts of urban planning. Within the grids of roads, spaces were set aside for consulate offices, churches, schools and places of business. ${ }^{8}$ The latter are epitomized by the great mercantile houses constructed on the embankment along the Huangpu River in what would come to be known as "the Bund." Together these foreign concessions transformed Shanghai into the most western city in China.

Fig 1.2

The Bund, 1928

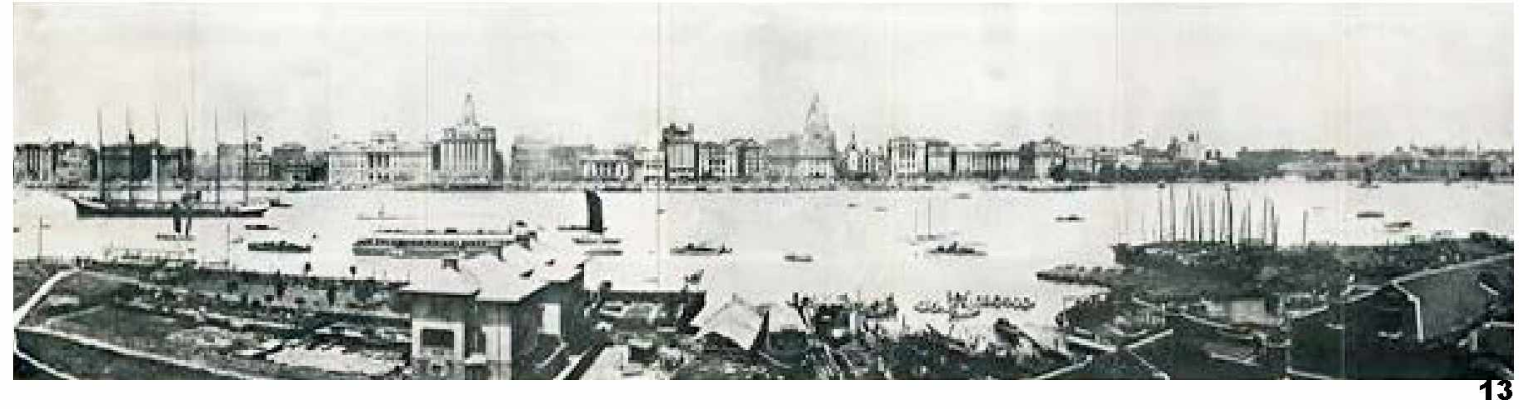




\section{Shanghai in the $20^{\text {th }}$ Century}

The Industrial Revolution and the Growth of Manufacturing

By the early twentieth century China had emerged as a major cotton producer with annual revenues of 1 billion dollars. It was referred to as "the land of the cotton grown." 9 The majority of the cotton textiles produced in China were hand loomed due to the lack of machinery. By and large the country's textile production was centered in Shanghai. Author F.L.H. Pott describes the reasons for this as follows:

1) It is surrounded by a prosperous cotton growing section of the country, and the cotton can be easily transported to Shanghai.

2) There is a great demand for cotton goods throughout China, and Shanghai is the principal distributing Centre for central and North China.

3) Shanghai has an abundant supply of Chinese coal. Shanghai has better financial facilities than any other city in China. 
4) Shanghai has a good supply of labor and has trained up a number of hands who have become experts.

5) It has a cheap supply of electricity. ${ }^{10}$

Moreover, after the Sino-Japanese War (1894-95), foreigners gained the right to establish manufactories in the city. Together these factors led to the increased activity in the erection of mills, which made Shanghai the cradle for cotton production in China.

\section{The Role of the Suzhou Creek}

In 1894, Sheng Hung Pao introduced mechanization into the manufacture of cotton textiles. He established his first Hwa Shen cotton mill in Shanghai with 65,000 spindles and 600 looms. ${ }^{11}$ It not only enhanced the total volume of cotton production but also reduced the labor required. Additional mills quickly followed, ushering in an industrial revolution in Shanghai.

For the purposes of receiving raw materials and shipping out finished goods, cotton mills and other manufactories tended to locate adjacent to navigable waterways. As such, Shanghai's Wusong River became the center of the city's industrial production. Also known as Suzhou Creek because it connects 
Shanghai with the city of Suzhou to the west, the Wusong meets the Huangpu River at the northern end of the Bund.

The Suzhou Creek has played an important role in the development of Shanghai. About $25 \mathrm{~km}$ of its $125 \mathrm{~km}$ length are within the current boundaries of Shanghai. For cotton production alone, Shanghai boasted 58 spinning mills, with 2 million spindles by $1933 .{ }^{12}$ Given its favorable situation for transporting goods into and out from the interior of the country, other industries (including flour manufacturing, silk production and ship building) located along the Creek. This, in turn, attracted more and more workers to the immediate area. While the expansion of Shanghai around these mills changed both the social and physical character of the city, the growth of manufacturing transformed Shanghai from a trade-oriented treaty port into a significant industrial center. Describng the city in 1928 , Pott notes that:

"As a traveller enters the harbour of Woosung, his attention is attracted to the numerous high chimneys belching out their smoke, and he becomes conscious that he is nearing the great industrial port of the East"13

With growth came diversity - not only with respect to 
the number of foreigners in Shanghai but in relation to the numerous populations from eleswhere in China that gravitated to the city for employment. The capitalist bent of the city, however, proved very much out of synch with the ideology of Communist Party, which came to power in 1949.

Fig 1.3

The Suzhou Creek within the Urban Context, 1935

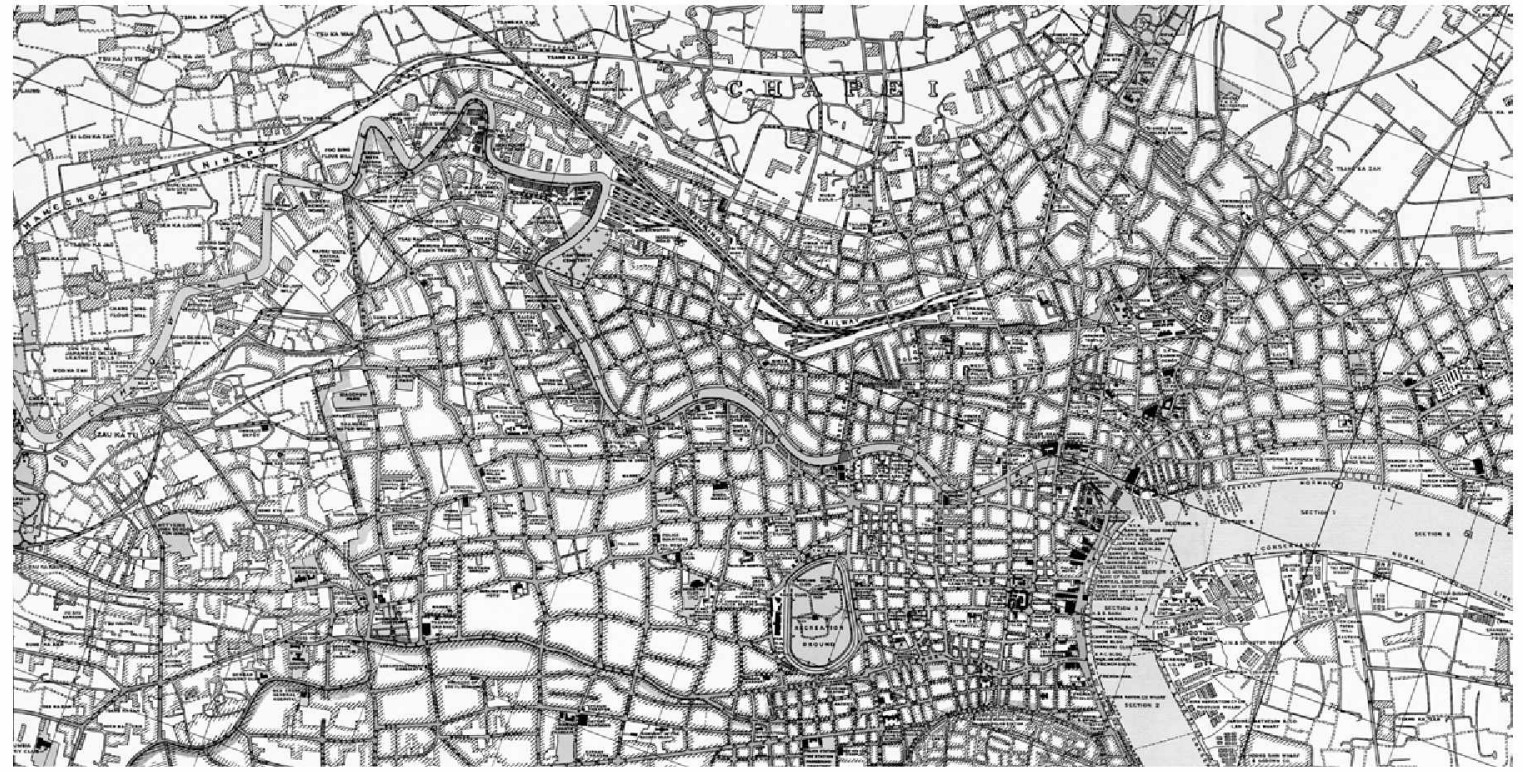

Fig 1.4

Factories along the Suzhou Creek

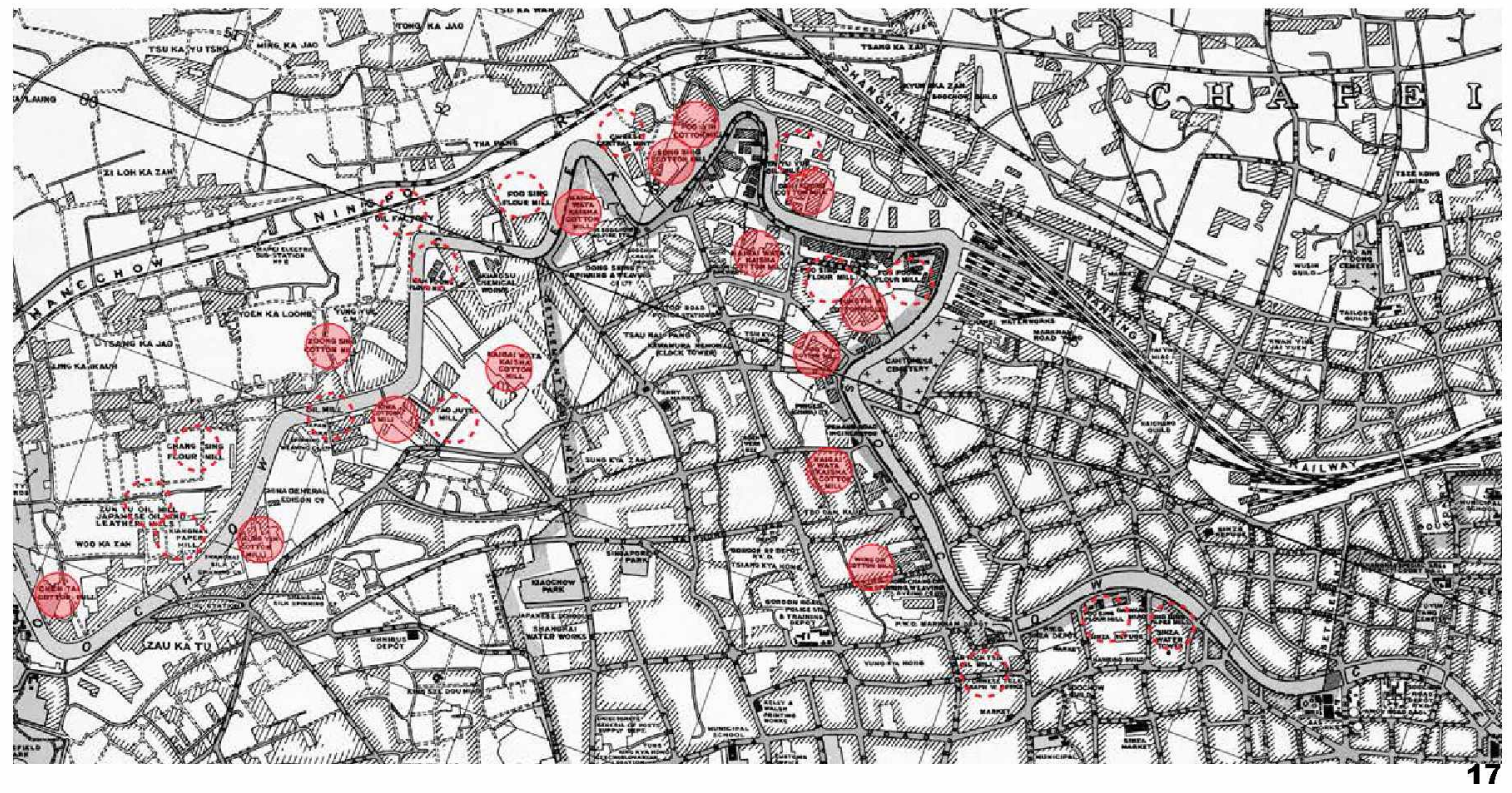




\section{Work Units and the Organization of Shanghai Under the Communist Regime}

China has experienced many vicissitudes from the 1920s onwards - including the sorry state of affairs arising from the conflict between the Communists and Chang Kai-shek, the Japanese invasion during the $2^{\text {nd }}$ World War, and the triumph of the Communist Party in 1949 - all of which affected Shanghai. Once in power, the Communists Party attempted to dismantle the great cities, or at least de-emphasize them. Shanghai, in particular, was considered anomalous and decadent - presumably too Western for emerging communist tastes.

Under the Communist government of Mao Zedong, private industry - which was all but destroyed by the end of WWII - was replaced by state socialism. The structure of work was both centralized and reorganized under the "Work Unit." or danwei. Chinese Work Units linked each individual, though his or her employer, to the central Communist Party infrastructure. The majority of urban dwellers, i.e., most of those who depended on a salary to feed themselves, were bound to Work Units associated with a state-owned enterprise. Work Units were responsible for all aspects of their workers' lives. In addition to employment, they 
provided housing, schools, shops, clinics, services and meals at centralized canteens. Permission from the Work Unit was required for things like travel and childbearing. The Work Unit also monitored the "one child" policy for its workers. Failure to comply with policies could result in docked wages or downgraded accommodations.

For much of the $2^{\text {nd }}$ half of the 20th century the Work Units created a critical link between non-agricultual populations and the central government for both employment and housing. It was effectively the system through which state welfare was administered. Many workers and their families were housed in tenements constructed and managed by their Work Units, for which they paid little or no rent. ${ }^{14}$ Given the scale of the undetaking, however, and the extremely modest per capita investment, living conditions were extremely rudimentary.

The 1966 Shanghai Land and Building Management Bureau Report noted that "in 1960 there were over one million persons (or perhaps $15-20 \%$ of the population) in "slum dwellings," of which one-quarter had grass roofs." ${ }^{15}$ The report includes a table showing the state of industrial worker housing in Shanghai in 1930. At the time there were four main dwelling types, 
namely 2-storey houses with a court, 2-storey houses with no courts, 1-storey houses with tile roofs and 1-storey houses with straw roofs. (Fig 1.5) Predictably the straw-roofed huts were of the poorest quality, supported by bamboo or mud walls with no windows, drainage or connections to water or sanitary sewers. The estimated cost of construction for these dwellings was about twenty dollars. On the other end of the specturm were 2 -storey houses with $150 \mathrm{ft}^{2}$ courtyards. Floors were made of cement rather than mud, most included plumbing for water and most rooms received natural light through windows. Notably courtyards were configured to permit sunlight to penetrate into the interior of the house. ${ }^{16}$ Housing reformers saw this as crucial, as it was believed that that sunlight could prevent disease.

Fig 1.5

Industrial Worker Housing in Shanghai, 1930

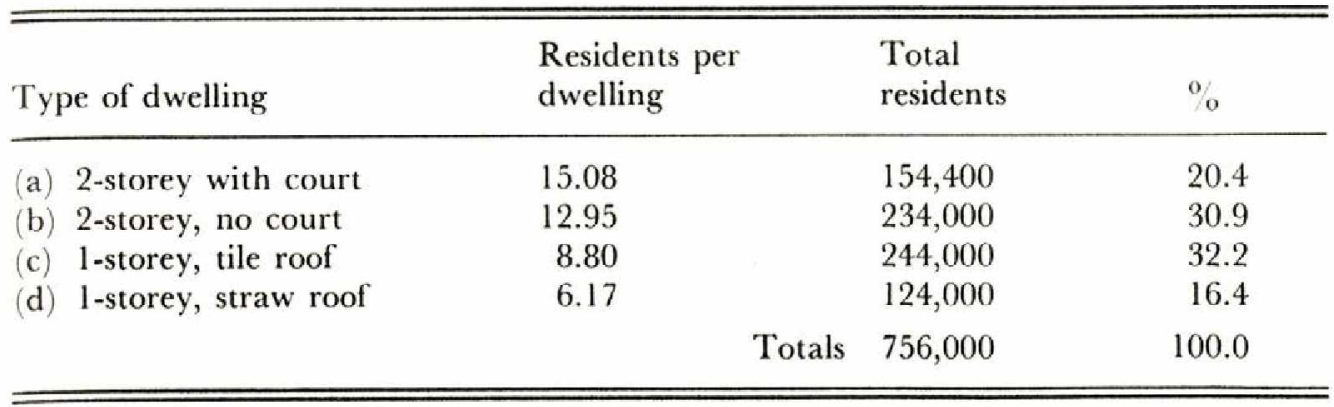

Source: Standard of Living, p. 139. 
Where the quality of housing was concerned, cities around the world were facing similar challenges. Throughout much of the $2^{\text {nd }}$ half of the $19^{\text {th }}$ century, for example, New York City struggled to find affordable alternatives to the "double house" or railroad tenement type in which many rooms received no direct light. The city experienced a large influx of foreign immigrants during this period, most of whom needed to live in close proximity to local businesses and factories. "As cheap as possible" ${ }^{17}$ was the predominant philosophy with respect to housing, much of which was crowded and unsanitary. Coming out of WWII, the situation was much the same in Shanghai, with workers of the lowest social status having the fewest choices while forced to pay the greatest proportion of their income for housing.

First appearing in the late nineteenth-century, Shanghai's lilong or alleyway houses are a cross between the traditional Chinese hutong or courtyard

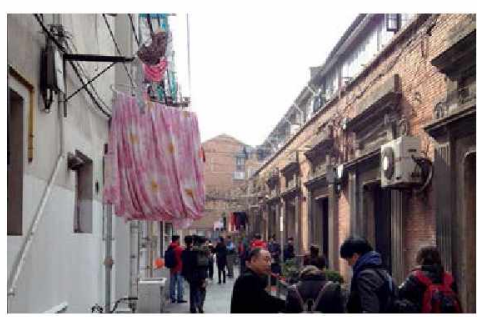

Fig 1.6 Alleyway House in Shanghai house and the Western terraced house. The alleyway type was used extensively in central Shanghai, adapted both for wealthier and lower-income households. Long, east/west rows of these houses were accessed through gates along the citiy's north/south streets. These gates could be locked at night, securing the interiors of what were, by Western standards, relatively 


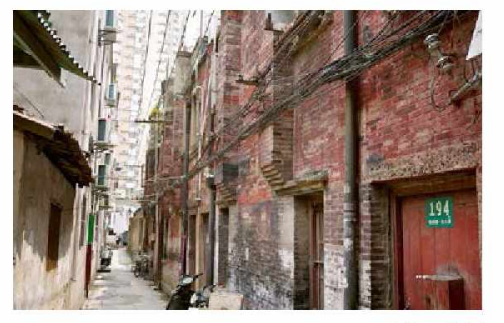

Fig 1.7

Typical Alleyway large urban blocks. While significanlty narrower then the public streets that circumscribed these residential compounds, the four- to five-meter width of alleyways was sufficient to enable the south-facing fronts of each dewelling to receive sunlight. Within the interior of the block, smaller, north/south alleyways were introduced as shortcuts. ${ }^{18}$

The attached houses along these alleys were two to four storeys high and varied in size according to the intended demographic. Oriented to the south, the fronts of these houses faced the backs of the houses in the next alley. The one-sided aspect of these repetitive rows of alleys reflects the Chinese preference to face south. Higher-end versions of the lilong houses incorporated shallow courtyards directly behind their south-facing facades, allowing them to be deeper without sacrificing access to sunlight. Similarly, alleys with taller (3- and 4-story) houses were wider than than those with 2-story houses.

The standard of housing in Shanghai improved significantly under the Communist Work Unit system. Between 1956 and 1973, 76 public living-quarters constructed by Work Units were built in Shanghai, the smallest of which included 35 buildings, housing 8,700 residents in $40,000 \mathrm{~m}^{2}$ of living space. ${ }^{19}$ 
"In the early years of the 1950s, some of these buildings were one-storey, but most of those built since 1960 have been 4-6 storeys. These 76 public-sector projects accounted for $25 \%$ of all housing in Shanghai in 1973. Because these projects were newly built, and because they were multi-storey, it seems certain that they offered a per capita living-area above the Shanghai average." 20

This housing typology departed from the traditional alleyway patterns of the Treaty Port era. The Work Units were given jurisdiction over relatively large parcels of land. This pattern of control reflects both pre-existing patterns and affected the size of blocks and the location of public infrastructure when these parcels were redeveloped in the Reform Era.

After Mao's death in September 1976, Deng Xiaoping assumed leadership and inagurated his "Reform and Opening" policy. The economic reform started in 1979 with a combination of regulation by plans and regulation by the market, to be followed latter by the implementation of the socialist market economy. Major efforts have been made to readjust the economic structure, and reform the economic and political system. One shift in policy is that the Central government no longer assumed sole responsiblity for 
the economic and social welfare of the country, forcing municipalities to seek out alternative sources of income. Cities attempted to attract foreign investment, primarily through manufacturing, capitalizing on the low cost of labor. Such initiatives created new cities like Shenzhen and brought others, like Shanghai, back to life. Over the course of the Reform Era, China, has tested out various forms of liberalization and modernization.

In the early 1980 s, the central government begain experimenting with the marketization of real estate assets in Shanghai, and an attempt was made to transfer state-owned housing to private ownership. Welfare flats once rented by the Work Unit at low or no cost quickly became a hot commodity. ${ }^{21}$ Throughout the 1990s, the government of Shanghai implemented a series of policies to enable individuals to enter the housing market. This marketization of urban housing had a profound impact on society and exerted tremendous pressure to develop real estate, which has greatly contributed to China's remarkable economic growth over the last two decades. 


\section{Shanghai in the $21^{\text {st }}$ Century}

\section{Transformation and Conflict - Demolition and Relocation}

Urban development in the Reform Era has been characterized by the widespread clearcutting of preexisting fabric to make room for office towers and appartment blocks. Shanghai has accommodated its rapid increase in population (10 to 23 million in two decades) in two ways: development on the periphery and intensification within the core. To accommodate the former, much of the existing fabric in the core has been torn down and replaced. Higher densities in the core both reflect market demand and take pressure off of the periphery.

In the past two decades, more than three thousand skyscrapers have been erected in Shanghai, ${ }^{22}$ most of which involved both the demolition of pre-existing residential fabric and the relocation of residents. The wholesale reconstruction of the city has been possible, in great part, because all land is state owned. Forced relocation resulted in violent battles between residents and pro-development municipal govenments eager to harvest money from land leases to fund infrastructure projects. While displaced residents frequently 
held out for the maximum compensation possible, usually in the form of a spacious, centrally located condominium, municipal governments typically offered the minimum possible to maximize the revenues from land development.

There were two phases of urban renewal. The first phase, in the 1980s and 1990s, generally replaced substandard housing with a higher quality of housing for existing residents. In many scenarios crowded one- and two-story dwellings were replaced with more widely spaced 5- and 6-story dwellings. Displaced residents were offered accommodations in these new structures.

The second phase of urban renewal, however, driven by the need to raise revenue for municipal projects, involved replacing low-scale, lower-quality housing with high-end private-sector condominium towers. Displaced residents were often pushed into towers on the far periphery where the cost of land (and by extension the cost of building) was significantly lower. The chief complaint was that residents did not benefit from of the increase in the value of the land they'd long occupied. In adddition, however, relocation frequently made it difficult (or in some cases impossible) to commute to jobs and fractured established social ties. 
While the quality of units into which the displaced were relocated was substantially higher and while residents were given "ownership" rights to their new units, many argued that the overal quality of the environment was lower and the quality of their lives significantly diminished.

Document 305, issued in 2001 by central government to guide demolition and relocation in urban Shanghai, made explicit mention of "the demands of the market economy." ${ }^{23}$ Document 111, subsequently issued by the government of Shanghai to address "Detailed Regulations on Shanghai City Housing Demolition and Relocation Management," took the hardline approach to residents one step further. Many local residents believed that these two documents were tantamount to an "evil law" that robbed them of their basic rights.

"... Document 305 stipulated that in case where residents disagreed with the demolisheronasettlement, relevant authorities could make an administrative ruling on demolition. If the residents objected to that ruling, they could, within three months, appeal their cases in court. But during the three-month period, the government could implement the demolition, by force if necessary." ${ }^{24}$ 
Document 305 neglected to take into account is the possibility that that the court might grant the appeal after the house had already been destroyed. However unlikely, this policy clearly legitimatized the use of force. Author Qin Shao notes that "the local government hired demolition squads to beat up resident protesters, vandalize their property, cut off their utilities, drag them out of their homes or even set their houses on fire to force them out." 25

In August 2005 a demolition squad committed arson five times in a neighborhood, causing the loss of two lives. The resulting public outrage prompted the Chinese State Council to issue Document 590 to replace the Document 305 in 2011. The new document prohibited some of the punitive regulations contained in the previous ones.

Nevertheless, demolition and relocation is a mandatory and crucial component of urban transformation. In the past 10 years, the average number of relocations has been 80 thousand units, creating 8 million $\mathrm{m}^{2}$ annually for urban re-development. ${ }^{26}$ Because land is state owned, municipalities like Shanghai cannot raise money through property taxes. "Expropriating" land in order to lease it to private developers, then, is a key source of municipal revenue. ${ }^{27}$ 
The Reestablishment of the Free Trade Zone and the Need for Additional Office Space

As China's largest city, Shanghai play an important role in the overall economic development of the country. By 2015 , the Tertiary economic sector (the so-called service industry) will account for $65 \%$ of Shanghai's GDP, as compared $57 \%$ in 2012 . This $8 \%$ increase consolidates Shanghai's role as a business (vs manufacturing) center and translates to an additional 270,000 new enterprises for the city. ${ }^{28}$ In order to accommodate this growth, a significant amount of both office and residential space must be constructed. The projected gap for office space in Shanghai is 40 million $\mathrm{m}^{2}$, equivalent to the construction of another eight office centers the size of Lujiazui, the business

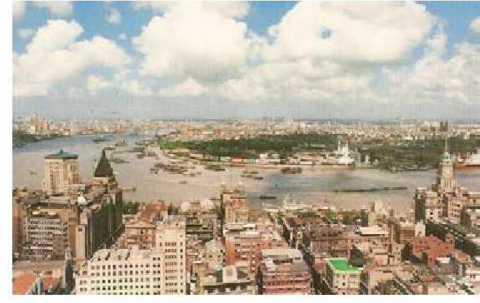

Fig 1.9 Lujiazui, 1990

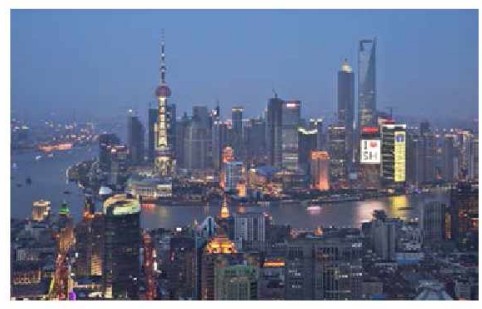

Fig 1.10 Lujiazui, 2010 area of Pudong. ${ }^{29}$

Lujiazui is a new, $32 \mathrm{~km}^{2}$ finance and trade zone developed by the government. It is located on the east side of the Huangpu river facing the old financial and business district of the Bund. The area comprises more than thirty office towers in which some 500 domestic and overseas financial and insurance corporations lease space. ${ }^{30}$ As one can imagine, the economic power of eight additional developments the size of Lujiazui is staggering and the escalation in the 
price of office rents is a foregone conclusion.

What's more, on September 29th, 2013, the Shanghai Free-Trade Zone was formally launched by the Chinese government. This pilot zone covers 28 $\mathrm{km} 2$ in four areas of the city, namely the Waigaoqiao Free Trade Zone, Waigaoqiao Free Trade Logistic Park, Yangshan Free Trade Port Area and Pudong Airport Comprehensive Free Trade Zone. ${ }^{31}$ The Free Trade Zone designation allows the Chinese RMB convertibility and unrestricted foreign currency exchange. Additionally, businesses locating in these zones are offered a 10-year break on municipal taxes. Baojun $\mathrm{Ai}$, the head of Shanghai's free trade zone administrative committee, reports that

"Over 1,434 companies had already registered in the zone, with a further 6,000 in the process of applying. Just two foreign banks established branches in the zone on its opening day, but that has risen to 12 , with HSBC and Deutsche Bank among the recent entrants." 32

Such Free Trade Zones (the first of which was Shenzhen in the late 1990s) are deemed to have had a huge impact on China's economic growth in the past two decades. 
Recent statistics indicate that, in 2012, the the cost of office space in Hong Kong - the most expensive in the world - was significantly higher than in New York and Tokyo. Even with the new Free Trade Zones, many experts believe that the cost of office space in Shanghai will overtake space in Hongkong in a short time. The figure of 40 million $\mathrm{m}^{2}$ of office usage is just an assumption; actual demand might far outpace this number. Besides the overseas enterprises, an increasing number of local companies are locating in Shanghai. As a result, supply can not keep pace with demand and office rents are quickly increasing. The average cost of office space in Lujiazui is $15 \mathrm{RMB}$ / day $/ \mathrm{m}^{2}$. While the highest rents in Shanghai, they are still considerably less than in Hong Kong, where office space averages $43 \mathrm{RMB} /$ day $/ \mathrm{m}^{2}$, 33 this gap both offers Shanghai a competitive advantage and represents a huge capacity for rents to increase. This suggests significant potential demand for office buildings in Shanghai, especially in the next decade.

\section{Conclusion:}

Shanghai has been torn apart and reconstructed siginifcantly in the last several decades. Much of the city's historical fabric - both industrial and residential - has disappeared in the process. 
Demand both for residential and office space in Shanghai is expected to remain strong for the forseeable future.

Large, centrally-located development parcels like the abandoned factory are fewer and farther between. This site is especially attractive both because of its riverfront location and the fact that no residents will have to be displaced in order to redevelop it.

The site represents not only an opportunity to both more traditional and experimental approaches to urban design, including the mixing of uses, but the opportunity to combine new and existing buildings in order to leverage and valoize Shanghai's vanishing industrial heritage.

To this end, Chapter 2 will examine a number of mixed use developments in Shanghai and well as examples of the adaptive re-use of the city's residential and industrial heritage. 


\section{Endnotes:}

1 Shanghai is one of several cities in China that has both metropolitan and provincial status.

2 In Chinese, "Xi" means west, "dong" means east and "Pu" means river, referring to the Huangpu.

3 Pott, F. L. Hawks. A short history of Shanghai, being an account of the growth and development of the international settlement. Shanghai [etc.: Kelly \& Walsh, 1928. Print, 2

$4 \quad$ Ibid, 10

5 Johnson, Linda Cooke. Shanghai: from market town to treaty port, 1074-1858. Stanford, Calif.: Stanford University Press, 1995. Print, 191

6 "Mu" is a Chinese unit for measuring land space. 1 "Mu" = 666.67 M2

7 Johnson, Linda Cooke. Shanghai: from market town to treaty port, 1074-1858. Stanford, Calif:: Stanford University Press, 1995. Print, 191

$8 \quad$ Ibid, 192

9 Pott, F. L. Hawks. A short history of Shanghai, being an account of the growth and development of the international settlement. Shanghai [etc.: Kelly \& Walsh, 1928. Print, 132

$10 \quad$ Ibid, 133

$11 \quad$ Ibid, 132

$12 \quad$ Ibid, 133

13 Ibid, 136

14 Shao, Qin. Shanghai gone: domicide and defiance in a Chinese megacity. United Kingdom: Rowman \& Littlefield Publishers, Inc., 2013. Print, 7

15 Howe, Christopher. Shanghai, revolution and development in an Asian metropolis. Cambridge: Cambridge University Press, 1981. Print, 233

$16 \quad$ Ibid

17 Wright, Gwendolyn. Building the dream: a social history of housing in America. New York: Pantheon Books, 1981. Print.

18 Bracken, G. The Shanghai alleyway house: a vanishing urban vernacular. London: Routledge, 2013. Print, 16

19 Howe, Christopher. Shanghai, revolution and development in an Asian metropolis. Cambridge: Cambridge University Press, 1981. Print, 234

20 lbid

21 Shao, Qin. Shanghai gone: domicide and defiance in a Chinese megacity. United Kingdom: Rowman \& Littlefield Publishers, Inc., 2013. Print, 9

22 Pridmore, Jay. Shanghai: the architecture of China's great urban center. New York: Abrams, 2008. Print, 8

23 Shao, Qin. Shanghai gone: domicide and defiance in a Chinese megacity. United Kingdom: Rowman \& Littlefield Publishers, Inc., 2013. Print, 9

$24 \quad$ Ibid, 10 
26 Yang, Hongxu "Relocation and Demolishing in Shanghai" Sina Blog March 292014 http://blog.sina.com.cn/s/blog_48f7836101000k7x.html

27 The leases, typically 30 years are paid out as a lump sum when the lease is signed. As "one-timeonly" revenue, the monies from these transactions do not show up on the balance sheets of municipal operating expenses. This gives the city a significant amount of flexibility in deciding how to use these funds. Lack of accountability, however, opens these transactions to corruption.

28 "Shanghai Office Buildings" XinMing Newspaper, September 4 2013. A4

$29 \quad$ Ibid

30 "Shanghai District Overview - Pudong" Knight Frank March 292014 http://www.knightfrank.com.cn/

31 "Shanghai Free Trade Zone Attracts 1,400 Companies" FINANCIAL TIMES March 292014 http://www.ft.com/cms/s/0/20b7714c-57fb-11e3-82fc-00144feabdc0.html\#axzz2nOYevep1

$32 \quad$ Ibid

33 "Shanghai Office Buildings" XinMing Newspaper, September 4 2013. A5 
CHAPTER TWO: The Different Approaches of Mix

Use in Shanghai 


\section{Introduction}

Shanghai is a poly-centric city-both with respect to business centers within and around the core and with respect to the series of satellite cities planned for the periphery. In the past several decades Shanghai has transformed itself from a drab industrial city to a gleaming corporate center. In the process, blue-collar, manufacturing jobs have given way to office jobs and low-rise housing has been replaced with tall apartment towers. Over three thousand skyscrapers of thirty or more stories have been constructed since $1992 .{ }^{1}$ As a result of this building boom, Shanghai now boasts more skyscrapers than New York. Where office space is concerned, the collection of super-tall towers in the newly developed Pudong District symbolizes the city's transformation.

Extensive collections of office towers can be found in four of Shanghai's districts, namely Pudong, Jingan, Luwan and Changhning. The Lujiazui development in the city's Pudong District is the most renown, overshadowing Gubei in Changning, Xintiandi in Luwan and office complexes in the Jingan district. With the exception of Lujiazui, which was planned from scratch on cleared industrial land, clusters of office towers have been inserted into existing urban 
fabric - along with rail and highway infrastructure to serve them. All four districts correspond to major hubs in Shanghai's expanding subway system.

The vitality of the largely single-use Lujiazui area is greatly determined by business hours; it's busy during the day but quiet after 6 PM. By contrast, Xintiandi is active at nights and on weekends. Xintiandi comprises a variety of uses and activities. Office towers were introduced into a district of traditional "shikumen" or "stone gate" row housing that were reconfigured to accommodate bars, cafes, restaurants, public plazas, shopping malls and a major park (constructed atop a parking structure). ${ }^{2}$ This mix of uses, complemented by the mixture of old and contemporary architecture, have made Xintiandi one of China's most successful "lifestyle centers." 3 
While different in character, Gubei and the Jingan districts are also fairly diverse. Here too, towers were inserted into established residential districts (the fabric of much of which was rebuilt), making them extremely lively from 9am to $6 \mathrm{pm}$, with a relatively shorter nightlife from $6 \mathrm{pm}$ to $9 \mathrm{pm}$.

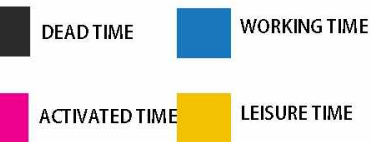

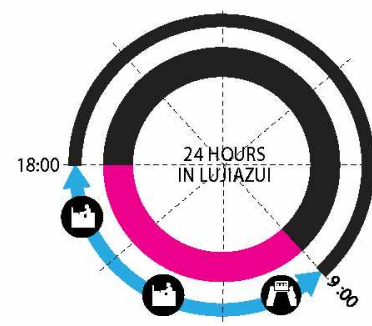

LUJIAZUI

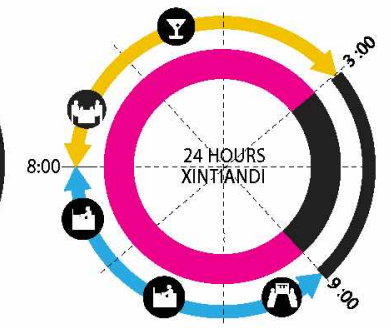

XINTIANDI

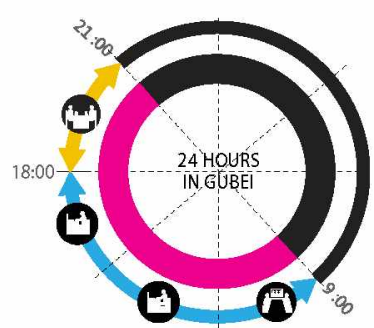

GUBEI



JINGAN

Fig 2.1 Activated Time Study 
The Mixing of Uses at Various Scales: the Building, Block and District

Unlike western cities where land is parceled into individually owned building lots, all land in Shanghai (and China) is state owned. Since 1949 control over land has been divided among state controlled industries or work units. While a typical building lot in New York City, for example, is $25^{\prime} \times 100^{\prime}$ and lots are bundled into blocks averaging 1.3 hectares, Shanghai's road network divides the city into parcels averaging 6.7 ha. As such, development - or, more recently, redevelopment - happens at a much larger scale in China than in many Western cities. Not only does development occur at the scale of the block (rather than the lot), but block sizes are significantly larger in Chinese cities than in the West.

Where residential development is concerned, Shanghai's rapid population growth in the Reform Era (1978 - present $)^{4}$ coupled with limited investment in housing in the previous era $(1949$ - 1978) placed the city under pressure to increase the quality and density of its housing stock. Reform-era transformation of the residential fabric of central Shanghai has occurred in two phases. Between 1980 and 2000, large parcels of the city's traditional lilong housing along with vast 
areas of so-called informal development (occupantconstructed squatter housing) were replaced with enclaves of 6-story walk-ups. These were, in many instances, similar to the danwei or "worker villages" constructed by work units in the Communist era. More recently, with the privatization of real-estate development and the rapid rise of land prices, portions of this mid-rise fabric (along with remaining areas of lilong and informal development) have been replaced with housing towers, many of which are thirty or more stories tall. But while the form and height of housing has changed, Shanghai's urban patterns have not. Like the older, lower-rise compounds, this new generation of high rises is organized into large, internally focused enclaves gated off from surrounding streets. The size of these enclaves reflects the size of the city's blocks - which are commensurate with the superblocks advocated by modernist planners.

In their defense, large-scale gated compounds are consistent with historical residential patterns in the city. Also, given the scale and pace of transformation that Shanghai has needed to manage in order to accommodate growth, redevelopment by the block (rather than lot) is more efficient and cost-effective. The scale of (re)development in Shanghai is consistent both with the size of the city and the scale of the 
problems it faced and headed into the Reform Era.

Typically blocks are developed as either residential or office, depending on their proximity to subway stops and other infrastructure. The result is a largescale patchwork of development with nodes of commercial punctuating an increasingly consistent sea of residential high-rises. While the overall pattern is heterogeneous, individual parcels are not. Again, there are both historical and cultural dimensions to this. The segregation of residential from office uses, however, is also consistent with modernist ideas of planning. That said, gated, residential-only enclaves frequently butt up against commercial buildings on adjacent parcels.

Although segregated at the scale of the block, uses can be mixed at the building level. Lujiazui's three, hyper-tall office towers, for example, each incorporate a hotel on the upper floors ${ }^{5}$ and a shopping mall in the base. Notably, however, none of the towers includes housing, despite the vast swaths of 6-story walk-ups and condo towers in adjacent residential blocks.

A notable exception to the segregation of office and residential uses is the SOHO model (small office/home office). Here housing and office uses are combined 
in the same building. Arguably, however, the SOHO model is less an exercise in integration than a refusal to distinguish between living and working. Providing each unit with a three-piece bath and plumbing for a kitchen sink allows it to be used in a variety of ways. In a rapidly transforming economy where demand for residential and office space is equally strong, the $\mathrm{SOHO}$ model is seen as both practical and flexible. In effect, the developer allows the market/occupants to decide how the building will be used on a unit-byunit basis. The target market is presumably young entrepreneurs or those who work from home.

And this brings us to another model, namely, the socalled Creative Industry Park (CIP) - envisioned as an incubator, of sorts. Here office space (for creative industries) is integrated with artists' studios, art galleries and retail venues, typically within an abandoned industrial building or compound. The CIP is a rougher, ad-hoc and publically supported version of the SOHOlikely acknowledging that cultural "industries" normally cannot survive without some sort of subsidy. CIIPs serve two purposes. First, they provide a genre of space for visual and performing artists that would not be affordable within the marketplace. Secondly, they are vehicles by which to preserve and repurpose the city's industrial heritage. 


\section{Case Studies}

This balance of this chapter examines seven examples of mixed-use development in Shanghai. These precedents are categorized according to the scale at which uses are integrated, i.e., building, block and district. The projects covered are the following:

Category 1: Buildings

Jin Mao Tower

Shanghai Tower

Shanghai 1933

Category 2: Blocks / Neighborhoods

Tianzifang

Red Town

Jianwai SOHO

Category 3: Districts

Xintiandi 
Category 1: Mixed-Use at the Scale of the Building

To understand current approaches to the design and mixing of uses within individual towers in Shanghai, research was conducted on fifteen Class $A$ office buildings. These were selected from the four districts in identified above. While only two are profiled in detail below, information on the others can be found in the Appendix.

\section{Precedent 1: Jin Mao Tower}

The Jin Mao Tower is a landmark skyscraper located in the center of the Lujiazui Finance and Trade District

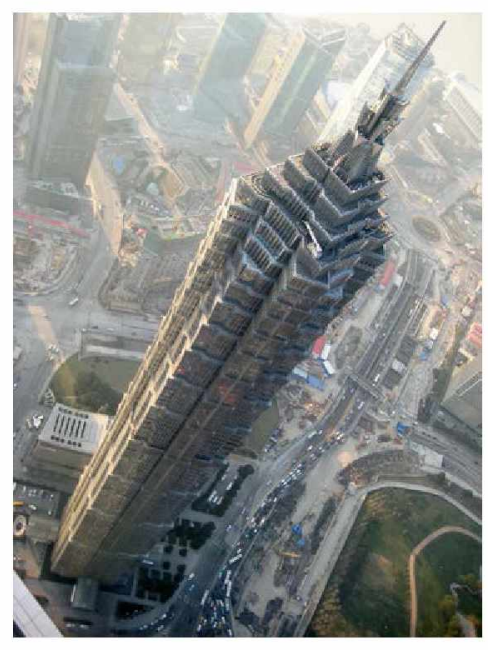

Fig 2.2 Jin Mao Tower in Shanghai's Pudong District. The 420.5-meter structure comprises 88 stories with a gross area of $290,000 \mathrm{~m}^{2}{ }^{6}$ Currently the Jin Mao Tower is the $3^{\text {rd }}$ highest building in Shanghai, after the Shanghai Tower (described below) and the Shanghai World Financial Center. The building includes entertainment facilities, an observation deck, banquet halls, exhibition halls, a hotel and office space. ${ }^{7}$ Offices from the third to the fiftieth floor are open-plan with a floor-to floor height of 4 meters and a floor-to ceiling height of $2.7 \mathrm{~m}$. Floors 53 to 87 are occupied by the Grand Hyatt Shanghai hotel, and are connected by a continuous atrium. ${ }^{8}$ 
The Jin Mao Tower was designed by Skidmore, Owings \& Merrill LLP (SOM), a Chicago-based architectural and engineering firm. Construction began at 1994 and was completed in 1999. The name "Jin Mao" means "Golden Prosperity" in Chinese. This reflects the aspirations of building's architects, builders and investors. Although the tallest building in China when completed, it was soon surpassed by the World Financial Center and Shanghai Tower. 


\section{Precedent 2: Shanghai Tower}

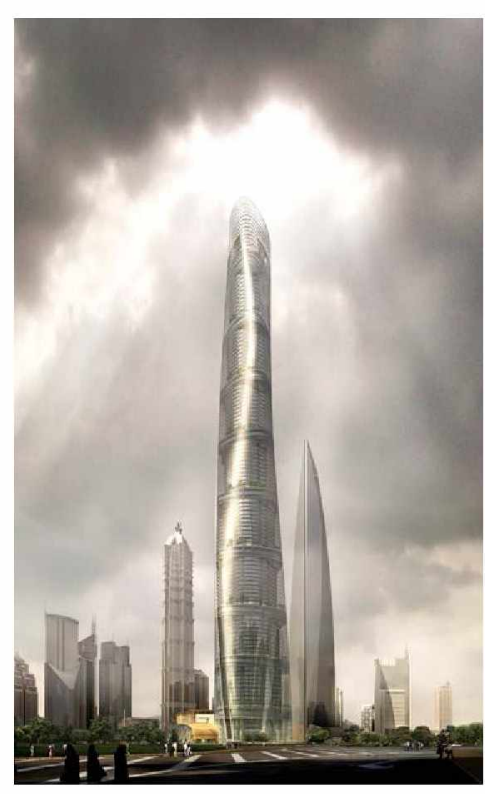

Fig 2.4

Shanghai Tower

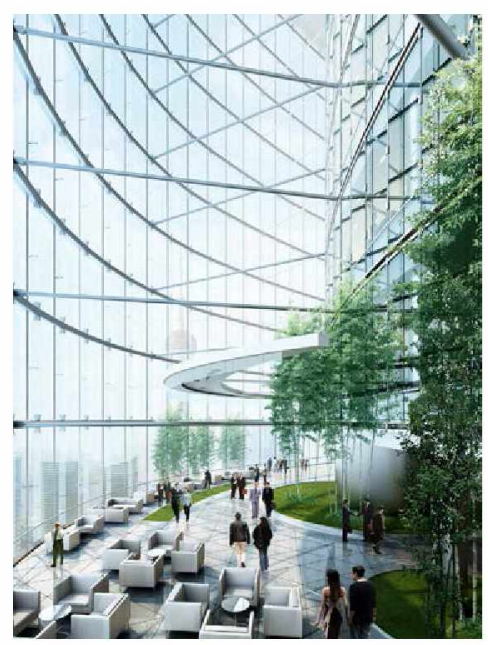

Fig 2.5

Building Atrium
Although not yet completed, the Shanghai Tower has already become a landmark at the heart of Pudong's Lujiazui Finance and Trade District - the third in a triad of super-tall towers (along with the Shanghai World Financial Center and the Jin Mao Tower). When completed in 2014 it will be the tallest building in China, and the $2^{\text {nd }}$-tallest in the world.. The Shanghai Tower will include 121 stories reaching a height of 632 meters. Enclosed area is $521,000 \mathrm{~m}^{2}$ and the floor space is $380,000 \mathrm{~m}^{2} .9$

The Shanghai Tower was designed by the Gensler Shanghai office. The lead architect, Jun Xia, incorporated many innovative ideas into its design. According to Mr. Jun:

"the new tower takes inspiration from Shanghai's tradition of parks and neighborhoods, recast in highdensity urban form. Its curved façade and spiraling form symbolize the emergence of modern China as a global financial power, while setting new standards for performance". ${ }^{10}$

For instance, the double curtain wall system of the tower significantly distinguishes it from traditional 
towers. Tall atrium spaces separate the inner and outer facades. While used for daily activities and social gatherings, these spaces also insulate the leasable floor space to minimize the energy loss from cooling and heating.

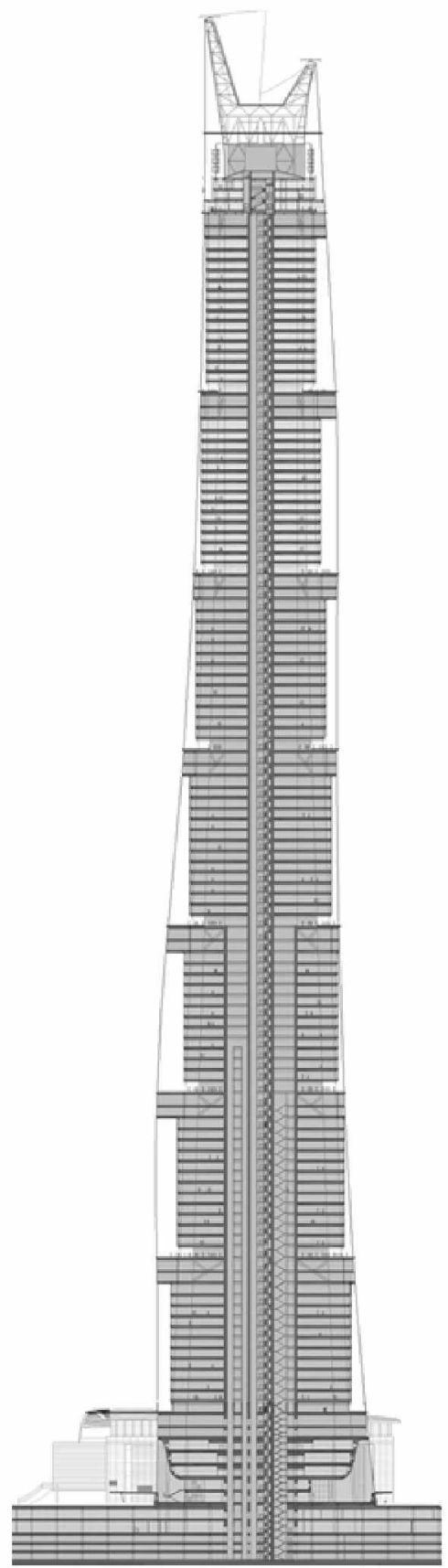

The tower is divided into 9 zones, as in Chinese culture the number 9 means "the largest" or "the best". Zone 1 is mainly for commercial and retail uses, Zones 2 to 6 are used for office space, a hotel occupies Zones 7 and 8 (half of which is shared with the boutique offices), and Zone 9 is occupied by an observation area and cultural facilities. According to the frim's cofounder Art Gensler:

"The Shanghai Tower represents a new way of defining and creating cities. By incorporating best practices in sustainability and high-performance design, by weaving the building into the urban fabric of Shanghai and drawing community life into the building, Shanghai Tower redefines the role of tall buildings in contemporary cities and raises the bar for the next generation of super-highrises" 11

Fig 2.6 


\section{Precedent 3: Shanghai 1933}



Fig 2.7 Shanghai 1933



Fig 2.8 Intertwining Bridges
Shanghai 1933 is a five-story building with an area of $31,700 \mathrm{~m}^{2}$ located in Shanghai's Hongkou District. Located slightly north of the Suzhou River, it is connected to it via a canal. The original building was designed by British architects and developed by Shanghai Municipal Council. ${ }^{12}$ Today, this building is a fashionable, creative design center in Shanghai.

Shanghai 1933 was constructed as a slaughterhouse. Cast entirely of concrete, the curved spaces of the structure might be described as Deco-Romanesque. Cement was imported from Portsmouth, Britain to meet the load-bearing needs of the building as well as ensure the sturdiness of the structure. ${ }^{13}$ All floors were connected to an outer shell through the use of various ramps and staircases, intertwining bridges and interlocking ramps. Cattles were guided up ramps while workers used spiral stairs cutting through the structure. ${ }^{14}$ The ensemble - which resembles one of Piranesi's Carceri, was designed to be easily hosed down. The cattle walkways were covered with rough pavement to prevent cattle from slipping.

In addition to functional details, some religious elements were incorporated in the design. For example, lattice 




Fig 2.9

Staff Stairway Encircling Core

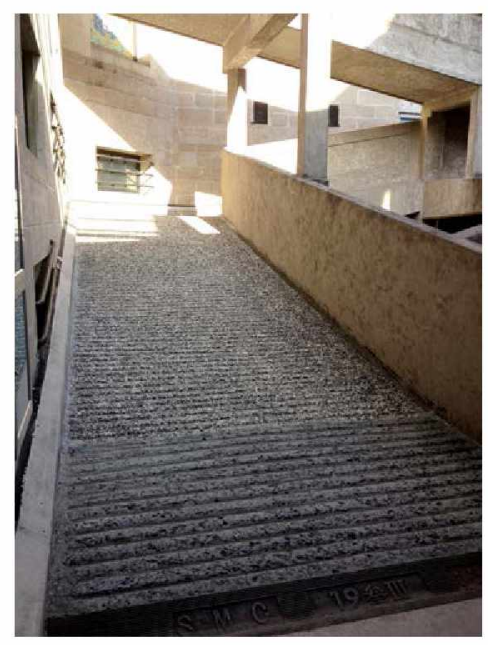

Fig 2.10 Cattle Walkway

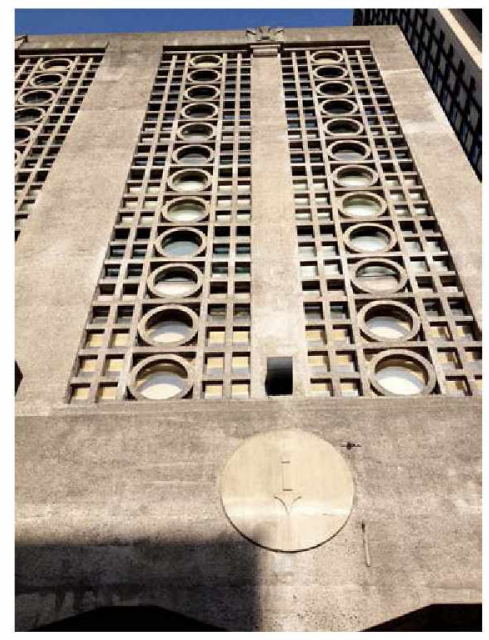

Fig 2.11 Lattice Window detail windows were installed on the west-facing façade in deference to the Buddha (who is seen to live in the west). This design represents the metempsychosis and exorcism for the slaughtered animals. On a more practical level, lattice caught prevailing winds that come mainly from the west to control the impact of smells from the facility on the adjacent neighborhood. From both a technical and architectural perspective, the building is a masterpiece.

The building changed functions several times, becoming first a cold storage facility then a medicine factory before being converted to its current use as an artistic and innovative design center. The most recent metamorphosis began in 1998 and was completed in 2008. The goal was to adapt the building to accommodate various public usages. To this end the central atrium which previously functioned as the workshop of the slaughterhouse, was converted into an auditorium. This space, on the fourth floor of the building, has an area of $1500 \mathrm{~m}^{2}$. Enclosed by a circular dome, the stage is supported by reinforced glass for visual impact. ${ }^{15}$

The building currently accommodates services for independent markets, events, weddings and other gatherings. 
"... The building has successfully held many high-end events for top brands such as the Ferrari F1 show, Rado 50th Anniversary Celebration, the Paris \& Design Expo, the Mercedes-Benz New Car Release Ceremony..." 16

Additional uses are still being explored for spaces in the Slaughterhouse. The successful preservation and renovationofShanghai 1933 reflects China'sremarkable progress in political, economic and cultural areas. It has also contributed to the revitalization of surrounding neighborhood, creating a mini cultural district in a fascinating (but hidden) corner of Shanghai. 
Category 2: Mixed-Use Blocks / Neighborhood Redevelopments

\section{The Creative Industry Park}

Creative Industry Parks (CIPs) can be seen as an alternative to office towers. Since 2005 some eighty such developments have appeared in Shanghai. As the city was the historic center of industry in China, a large number of factory buildings were constructed in the 1920s and '30s. About two-thirds of the city's CIPs are located industrial buildings, leveraging such advantages as flexible space, low rents (related to rudimentary finishes and services) and distinctive architecture character. These aspects are particularly appealing to creative designers and artists. "The creative industries in Shanghai have made outstanding achievements under the leadership of the municipal government. The value added generated by the creative industries has increased from 49.3 billion yuan in 2004 to 134 billion yuan in 2010, and the percentage in the overall GDP of the city has increased from $5.8 \%$ to $7.84 \% " 17$

As Suzhou Creek was the primary industrial artery flowing through the city, a number of CIPs are located along or near it. These include the M50 Complex, 
the $\mathrm{E}$ warehouse and SuHeHui. For the purposes of this exercise, however, I have chosen to examine the Tianzi fang and the Red Town, since Tianzi fang is developed from a residential district whereas Red Town is developed from an abandoned steel factory. The analysis of both case studies one suggests that the use of CIPs to regenerate pockets of the city's industrial heritage has reached a level of maturity.

\section{Precedent 4: Tianzifang}

Tianzifang is another notable creative industry center in Shanghai, although its roots are both residential

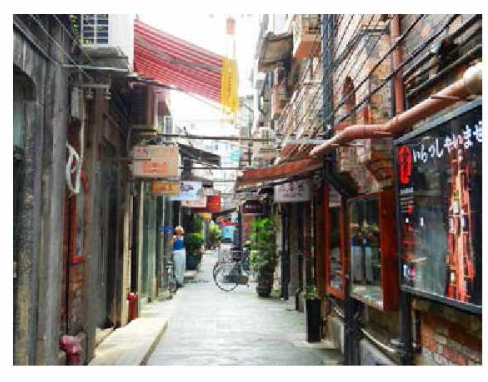

Fig 2.12 Tianzifang and industrial. Located in the Luwan District in the southwest corner of the French Concession, it is a conversion of an enclave of lilong housing dating to the period of the Nanjing National Government (late 1920s and '30s). Today's Tianzifang has been transformed from legacy factories and residential architecture into a stylish, artistic and creative hub with various boutiques, galleries, art studios, narrow alleys, crafts shops and so on, all of which attract a large number of expatriates, artists, designers, trend setters, and yuppies. ${ }^{18}$

The Tianzifang residential district was originally planned in the mid of 1930 s as rows of Shikumen 
houses. "Shikumen", literally meaning stone doors, is the highlight of Shanghai's traditional residential buildings which demonstrate a combination of different

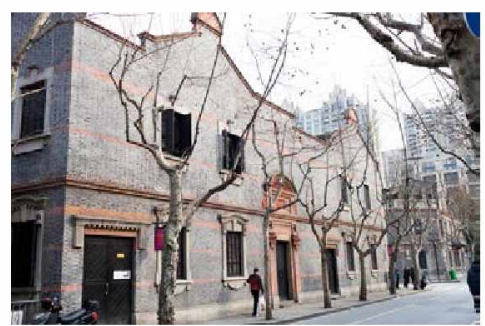

Fig 2.13 Typical Shikumen Architecture

architectural tastes. ${ }^{19}$ Shikumen buildings were usually organized into multiple labyrinthine alleyways, making Tianzifang difficult to find from the major streets, with only few laneway entrances. It now has become one of the Shanghai's most popular tourist destinations and a rare pocket of the city's cultural heritage.

The adaptive reuse of Tianzifan is relatively recent. The area remained remained unchanged until 1998 when one of best-known contemporary artists, Chen Yifei, rented two abandoned Shikumen buildings, which renovated into a art studio and painting shop. ${ }^{20}$ The area soon became popular with artists. Huang Yongyu, the dean of the Chinese Painting Circle, christened this new art center "Tianzifang" which means the "prosperity of workshops." Between 2005 and 2006, the area around Tianzifang was rezoned to permit additional art studios and schools. Since then, over 200 small businesses have opened in the area attracting large numbers of tourists. Yvonne Wang, a shop-owner and resident states that

"This area is quite unique and has more personality and character than many other places in Shanghai, 
there are also lots of new shops, but the character of the buildings has stayed the same" 21

In conclusion, the adaptive transformation of Tianzifang into a mixed-used district has been quite successful, proving heritage conservation can be economically viable.

\section{Precedent 5: The Red Town}

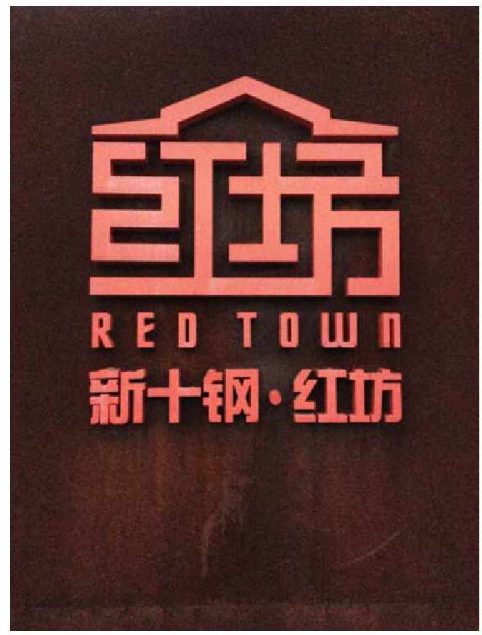

Fig 2.14 Red Town Logo
The Red Town is a well known creative district, located on Huaihai West Road in Shanghai's Changning District. It is comprised of a modern sculpture garden, the Minsheng Art Museum, crafts shops, cafes, many art studios and galleries. Together Red Town occupies some $50,000 \mathrm{~m}^{2}$ with a total floor area of $45,000 \mathrm{~m}^{2} .22$ It accommodates cultural property investment and management agencies and cultural event organization, focusing on renovating and redeveloping industrial heritage, promoting city development and developing culture industry in Shanghai.

Red Town has been redeveloped from the 'rattletrap,' abandoned ruins of the former Shanghai No. 10 Steel factory. After the 1950s, under the aegis of industrial reformation, old factories were abandoned, including Shanghai No. 10 Steel factory. ${ }^{23}$ With the spread 


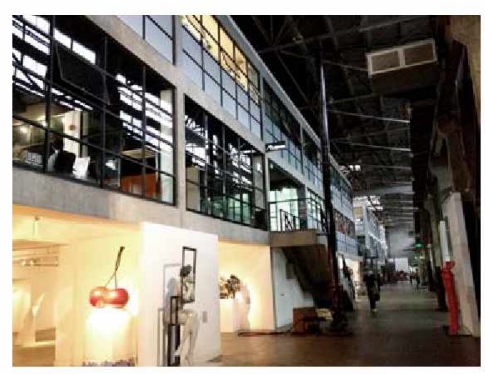

Fig 2.15

Interior Space 1

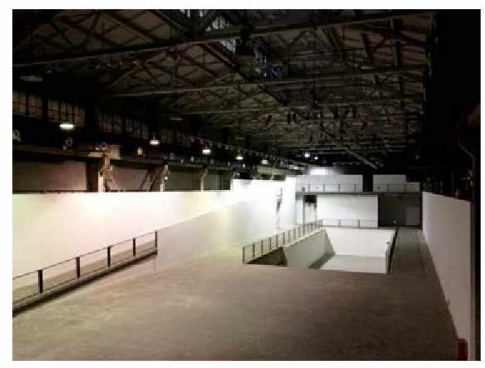

Fig 2.16

Interior Space 2

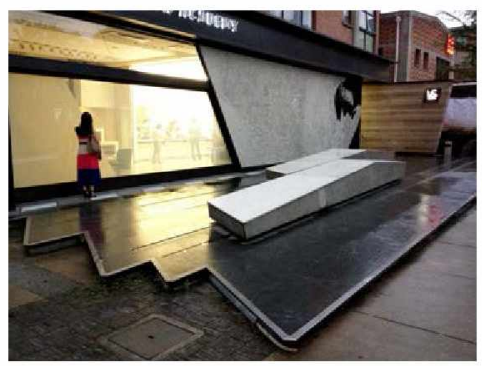

Fig 2.17 Red Town Gallery

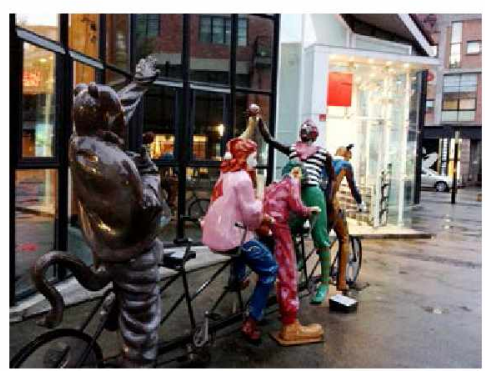

Fig 2.18 Art Sculpture in Red Town of the concept "regeneration" at the global level, factories like these have come out of the shadows. Like London's Tate, MoCA in Massachusetts and the Rocks in Sidney, the Red Town has become one of Shanghai's new landmarks, symbolizing both the revalorization of culturalal legacy and the pursuit of modern urbane culture.

The red town contains $23,000 \mathrm{~m}^{2}$ of leasable office space, including space for artists' studios - for which the former industrial buildings are well suited. Most of the former plant buildings were modernistic in style with concrete floors, red brick walls, and metal-sash windows. The overall character of the compound has also been preserved with the use of vintage road signs and streetlights.

Although Huaihai Road is one of the most prosperous and fashionable business streets in Shanghai, the central green space makes Red Town a bit of an oasis. This $8000 \mathrm{~m}^{2}$-area is used as a sculpture par. and gathering space - making Red Town "... popular with families and weekenders who come to picnic among the freestanding sculptures in the grassy central areas." 24 
In summary, Red Town complements the clamor and bustle of the modern city with its distinct architectural structures, cultural resonance and nontraditional uses. Shanghai City Sculpture Art Center, the Minsheng Art Museum and various art and design studios enrich the artistic atmosphere, while a large number of high-end stores, have moved in to take advantage of the location, the and Red Town's exquisite scenery.

Fig 2.19 Red Town Central Green Space with Sculptures

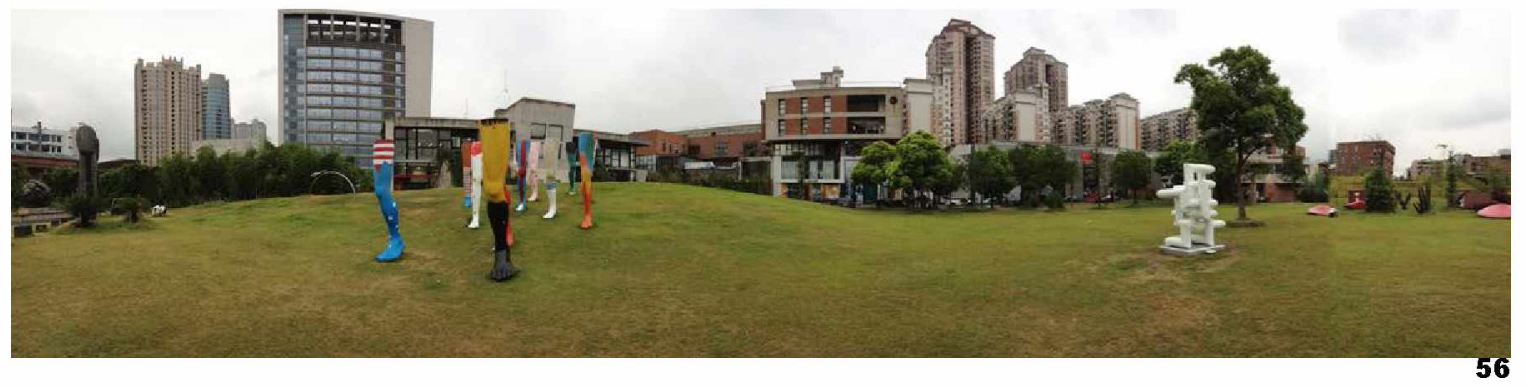




\section{Other Examples of Mixed-Use at the Scale of the Block}

As the president of SOHO China, Shiyi Pan and his wife, Xin Zhang, co-founded SOHO China in 1995. The company focuses on developing high-profile commercial properties. ${ }^{25}$ In 1999, the concept of "SOHO", which, in this case translates, to "Small Office, Home Office", was initially proposed in an article entitled "SOHO Modern City - Home \& Office." Shiyi Pan and SOHO China have received a lot of attention by numerous domestic and foreign media.

"The company collaborates with internationallyacclaimed architects, translating their innovative designs into iconic real estate which possesses strong appeal to property investors and the local businesses and customer bases which they serve. SOHO China has played a leading role in China's urbanization." 26

SOHO China has developed 17 properties in Beijing and successfully expanded into and established its presence in Shanghai. The Jianwai SOHO, the proofof-concept project constructed in 2004, provides a good example to demonstrate the concept. 


\section{Precedent 6: Jianwai SOHO}

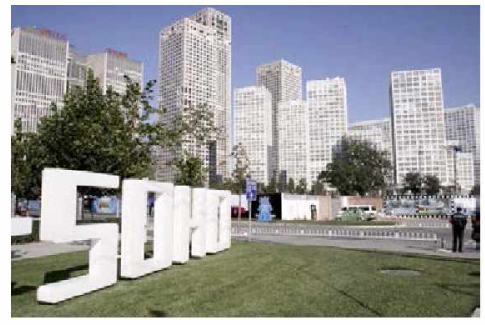

Fig 2.20 Jianwai SOHO



Fig 2.21

Site Circulation

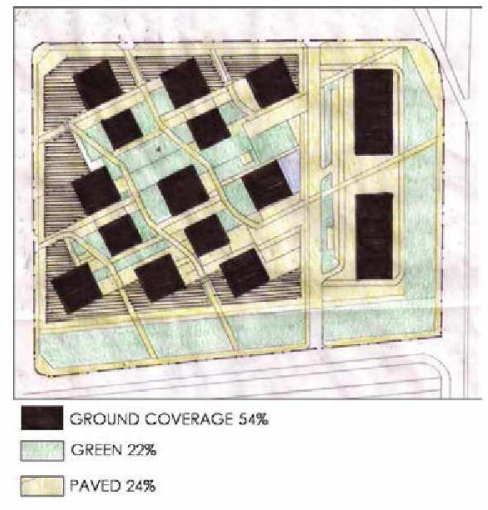

Fig 2.22 Land use Pattern
Jianwai $\mathrm{SOHO}$ is the largest construction project in Beijing's CBD, located at 39 East $3^{\text {rd }}$ Ring Road. Situated in the central area of the CBD, the complex is located close to the Guomao Subway Station, which is served by 2 lines - an ideal place for both commercial and residential uses. ${ }^{27}$ Jianwai $\mathrm{SOHO}$ has a total gross floor area of $700,000 \mathrm{~m}^{2}$ distributed over a 16.9 hectare site. Program is divided among thirteen mixed- use buildings and two office towers. The complex incorporates twenty rooftop gardens and sixteen pedestrian lanes. Various community facilities have also been provided such as a kindergarten, a large-sized private club, retail, etc. ${ }^{28}$

Jianwai SOHO's designer, Riken Yamamoto, created multiple pedestrian walkways at grade connected to parking and vehicular circulation below through public courts. ${ }^{29}$ By opening a "residential" enclave to the city at large, the architect broke from tradition. Residential precincts in China are normally walled and gated to protect them strangers and to segregate rich form poor. No such boundary exists in the Jianwai SOHO. All buildings in the compound are rotated 35 degrees from the street grid (and true north) to maximize solar orientation. In most buildings the north corner -- which 
receives the least light - is used for elevators and communal rooms while spacious units occupy the others. ${ }^{30}$

In addition to the thirteen mixed-use towers (office \&

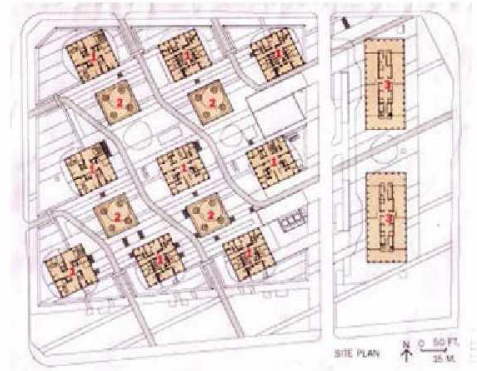

Fig 2.23 Building Orientation

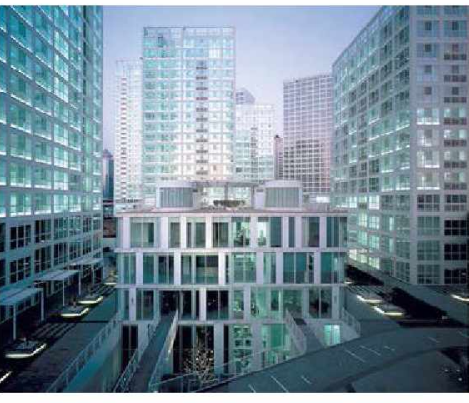

Fig 2.24 View of jianwai $\mathrm{SOHO}$ residential - with restaurants and retail on the lower three floors) in Jianwai SOHO, the compound also includes two 28-story office buildings with rectangular foot prints which located on the eastern side of the community - each with $98,000 \mathrm{~m}^{2}$ of office space. The SOHO central garden is composed of 20 small two-level gardens covering $30,000 \mathrm{~m}^{2}$. The $28,000 \mathrm{~m}^{2}$ private club includes a bar, massage room, sauna I steam room, gym, tennis court and a swimming pool.

The Jianwai SOHO demonstrates the architectural concept of "small" in the length of its streets, the size of its squares and in the dimensions of building footprints. While it lacks a discernable center, the community is tied together by multiple layers of circulation. In all the complex contains more than 300 shops and accommodates nearly 50,000 people. ${ }^{31}$ 


\section{Category 3: Mixed-Use at the Scale of the District}

\section{Precedent 7: Xintiandi}

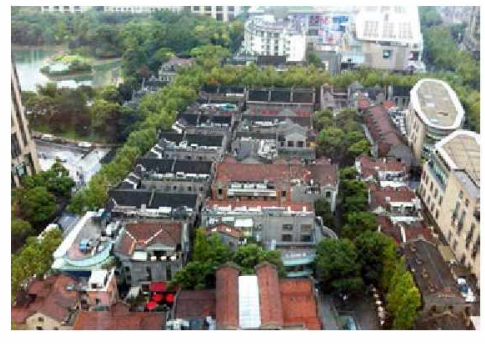

Fig 2.25

Aerial View of Xintiandi

The Chinese word Xintiandi translates to "New World". In Shanghai, it refers a fashionable, twoblock pedestrian street in central Shanghai, bordered by shikumen and modern architecture. It is part of a larger-scale redevelopment in the Taipingqiao area of Luwan District.

The redevelopment of the Taipingqiao area dates to 1996, and was initially proposed by Hong Kong based Shui On Land Ltd. ${ }^{32}$ The idea was to transform the area into a mix of high-end commercial, residential, and entertainment facilities. Believing that Shanghai would become an important international metropolis in the 21st century, Vincent H S Lo, the chairman of the Shui On Group, proposed:

"To abandon the residential function of shikumen, and promote its role as a business district, turning the centennial antique quarter into a world full of vitality, vigor and cultural prestige." 33

Having broken ground in 1999 with a budget of $\$ 150$ million, the first phase, including Xintiandi Plaza, 


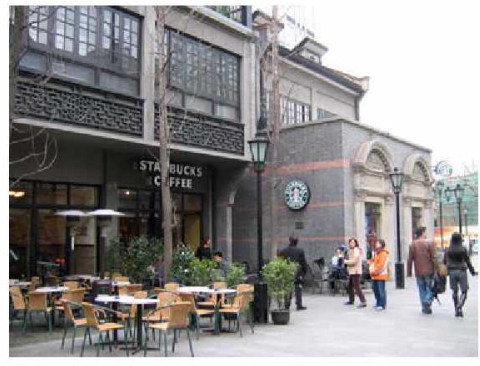

Fig 2.26

Shikumen Buildings re-Purposed for Commercial Use

was completed in 2001 . Although initially slated to be demolished, one of the shikumen houses in the neighborhood was historically significant as the location of the first meeting of the Communist Party of China (CCP). Although important to Shanghai's history, the shikumen houses and tight alleyways (or lilongs) into which they were organized, had fallen out of favor by the mid-20 th century. Largely driven by the desire to preserve the CCP headquarters, a number of rows of shikumen escaped the wrecking ball and were integrated into the redevelopment project. By and large they were converted into restaurants and retail spaces. While the facades were restored (and in some cases rebuilt), interiors were upgraded and redesigned.

Xintiandi can be divided into a northern and southern portion. While the South Block is comprised primarily of newly constructed buildings, the preserved shikumen - quite different in their use and density than what once existed existed - lend a nostalgic character to the North Block. Xintiandi also includes Taipingqiao Park,

Fig 2.27 Taipingqiao Park

designed by Skidmore, Owings and Merrill. The park was constructed over an underground parking garage with 200 spaces. The curving steps that form the eastern edge of the pond in the park are reminiscent of the surging coping on a traditional dragon wall. ${ }^{34}$ 


\section{The "problematic" of Different Approaches}

Where Shanghai is concerned, the tall office tower is primarily associated with the Pudong Lujiazui area, the business center developed in the 1990s to take pressure off the established business area in Puxi. Lujiazui represents the apogee of the tower precinct and celebrates the office tower as an iconic, sculptural element in a stand-alone office district. While skyscrapers optimize density in relation to building footprint and can be dropped into the existing urban fabric, they also have negative impacts. Towers can negatively affect the natural environment, block views and sunlight for other buildings, cause land subsidence and are extremely expensive to build and maintain. The Shanghai Tower, for example, cost $\$ 2.5$ billion to construct, making the payback period extremely long.

At the other end of the spectrum, low-scale, lowdensity Creative Industry Parks are booming. As noted, some $80 \mathrm{CIPs}$ appeared in Shanghai between 2005 and 2013. Redeveloping abandoned factories helps preserve the city's culture and history. Given the high cost of land in Shanghai and the need to raise money through land leases, however, this approach is typically not commercially viable and is limited to 
subsidized cultural or institutional usages.

Rather than building an iconic high tower, $\mathrm{SOHO}$ China president Shiyi Pan commissioned a complex of lower towers to create an integrated commercial and residential enclave. In so doing, however, he swept away the pre-existing urban fabric. Ideally architecture should both respect urban heritage and adapt to its context. Jinwai SOHOs repetitive concrete-framed buildings with their uniform elevations may lend it a unique character but the ensemble is quite alien and mute from a cultural perspective. Arguably it neither draws on nor contributes to the city's cultural heritage.

\section{Conclusion}

As is evident from the case studies above, neither the mixing of uses nor the adaptive reuse of industrial buildings is a new idea - nor is it is uncommon in Shanghai. As such, my proposal for the redevelopment of the Shanghai No. 1 Textile factory site draws upon aspects of each of these precedents. In so doing, however, I will propose a hybrid form of development where new and old, commercial, residential and office uses co-exist on a single parcel. The goal is to redefine this parcel is a manner that respects the history of the site and complements the adjacent context. 


\section{Endnotes:}

1 Pridmore, Jay. Shanghai: the architecture of China's great urban center. New York: Abrams, 2008. Print,8

2 Taipingqiao Park. Part of a 52 acre redevelopment master-planned by SOM.

3 Wu, Weiping, and Piper Rae Gaubatz. The Chinese city. Abingdon, Oxon: Routledge, 2013. Print, 166

$4 \quad$ The city added 6 million people between 2000 and 2012.

Cox, Wendell. "SHANGHAI: TORRID POPULATION GROWTH" April 172011 Newgeography_April 022014 http://www.newgeography.com/content/002187-shanghai-torrid-population-growth

5 The Grand Hyatt occupies 34 floors of the Jin Mao tower, the Park Hyatt occupies 14 floors of the Shanghai World Financial Center, and a hotel will occupy zones $7 \& 8$ of the Shanghai Tower

6 "Jin Mao" China Jin Mao Group CO., LTD February 102014

http://www.jinmao88.com/en/jinmao_edifice.htm

7 "Jin Mao Tower" 2013. Travel China Guide February 102014

http://www.travelchinaguide.com/attraction/shanghai/jinmao.htm

8 "Jin Mao" China Jin Mao Group CO., LTD February 102014

http://www.jinmao88.com/en/jinmao_edifice.htm

9 "Shanghai Tower" 2013 The Skyscraper Center February 182014

http://www.skyscrapercenter.com/shanghai/shanghai-tower/

10 Gensler. "SHANGHAI RISING" 2014 Gensler Design Update February 162014

http://du.gensler.com/vol5/shanghai-tower/\#/shanghai-rising

11 "Gensler topes out China's tallest tower in Shanghai" August 3, 2013 The A to Z of Building February 182014

http://www.azobuild.com/news.aspx?news $1 D=17107$

12 "The Last Slaughterhouse on Earth: 1933 Shanghai" 2011, Lasasapark 2011 February 32014

http://www.lacasapark.com/la/2011/11/the-last-slaughterhouse-on-earth-1933-shanghai/

$13 \quad$ Ibid

14 Martin, Dylan "Shanghai's 1933 Slaughter house" 2014, Atlas Obscura February 32014

http://www.atlasobscura.com/places/1933-slaughterhouse

$15 \quad$ Ibid

$16 \quad$ Ibid

17 "Shanghai Creative Industries Demonstration and Service Platform" 2010 CreativeCity March 1

2014

http://www.creativecity.sh.cn/en/

18 “Tianzifang” 2013. Travel China Guide March 62014

http://www.travelchinaguide.com/attraction/shanghai/tianzifang.htm

$19 \quad$ Ibid

$20 \quad$ Ibid

21 Andrew Yang. March 42007 "A high-fashion lane in Shanghai" The New York Times March 32014 http://www.nytimes.com/2007/03/04/travel/04surfacing1.html?_r=0 
22 "Shanghai Red Town Introduction" 2012. Legend February 222014

http://wenku.baidu.com/link? url=dgvQFjSCRNBjrTY9rRCsbu3h6RHZH4skSndJD9H17eScJRTsOjZR_q34gEEh/3l/KmTFg8XyuQPwPCOGEPd4Bu/ThiRnfOMnoRhHTE3vC

23 Ibid

24 "Red Town" 2011 City Weekend Shanghai February 162014

http://www.cityweekend.com.cn/shanghai/listings/travel/city-attractions/has/red-town/

25 SOHO China "Company Profile" SOHO CHINA March 062014

http://www.sohochina.com/en/about

$26 \quad$ Ibid

27 SOHO China "Jianwai SOHO" SOHO CHINA March 062014

http://jianwaisoho.sohochina.com/

28 "Jianwai SOHO" 2007. Beijing Real Estate March 052014

http://www.beljingrealestate.com/retail_sale_product_detail.asp?Product ID=669\&CategoryID=354

29 "Urban Design: Jianwai SOHO, Beijing" 2010. Archinomy March 052014

http://www.archinomy.com/case-studies/1156/urban-design-jian-wai-soho-beijing

$30 \quad$ Ibid

$31 \quad$ Ibid

32 Shao, Qin. Shanghai gone: domicide and defiance in a Chinese megacity. United Kingdom: Rowman \& Littlefield Publishers, Inc., 2013. Print, 91

33 "Development Objectives" 2012 XINTIANDI STYLE April 042014

http://www.shanghaixintiandi.com/xintiandi/en/about_info.asp

34 "Taipingqiao Park, Xintiandi" October 212008 Gardenvisit. Com April 042014

http://www.gardenvisit.com/garden/taipingqiao_park_xintiandi 
CHAPTER THREE: Design Proposal 


\section{Introduction}

The thesis proposes an integrated complex on an abandoned industrial site in central Shanghai. The approach is somewhat new for the city where residential and non-residential uses are not normally mixed within a single development parcel and where existing industrial buildings are rarely incorporated into new development. By setting fairly aggressive density targets for the open areas of the site and assigning institutional uses to a number of the existing buildings, the proposal attempts to balance economic viability with a respect for the site's heritage.

\section{Site Analysis}

\section{Introduction to the Site}

The site chosen is an abandoned factory in Shanghai's Changning District. It is the former location of the "Shanghai Number One Textile Factory," a number of buildings from which remain. Its size and desirable location within central Shanghai make the site an ideal candidate for redevelopment. 


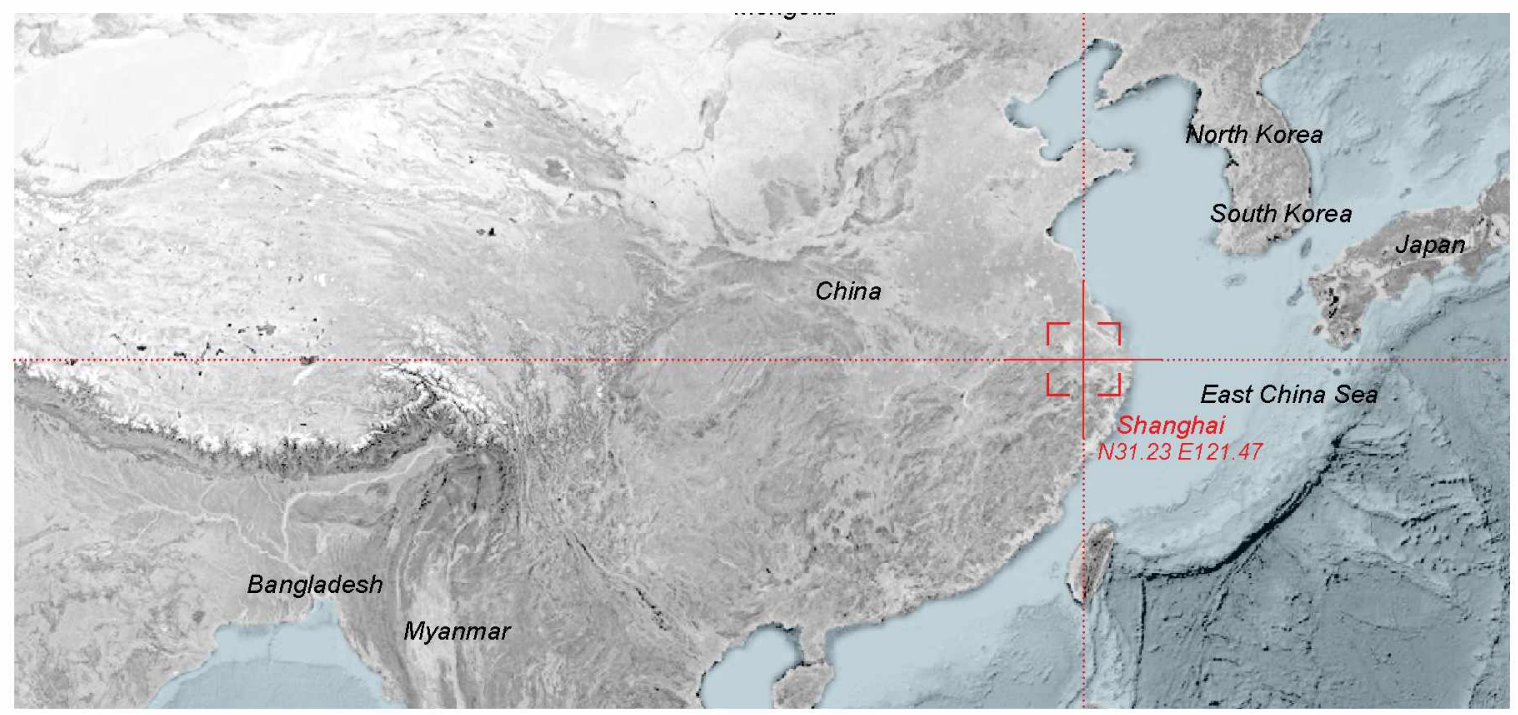

Fig 3.1 Location of Shanghai within China

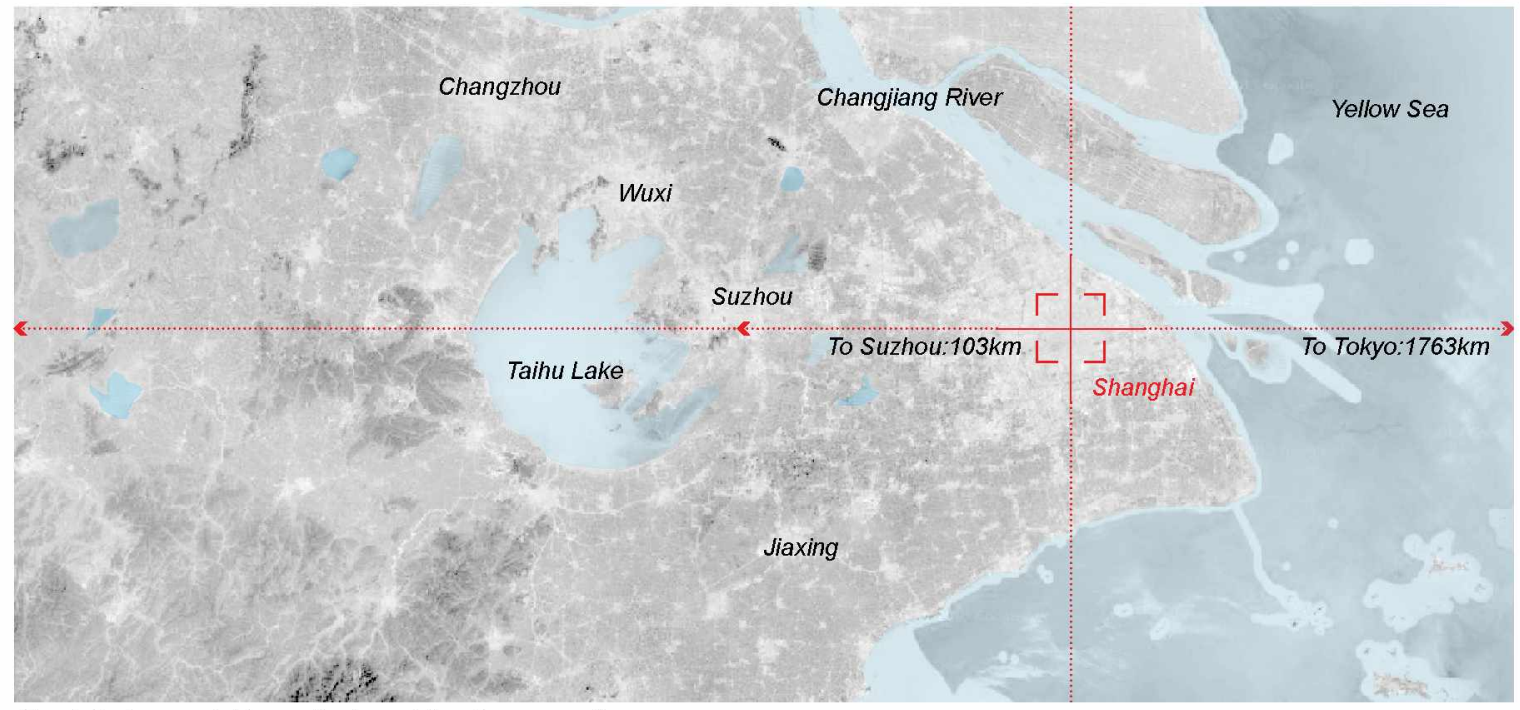

Fig 3.2 Central Shanghai and Its Surroundings

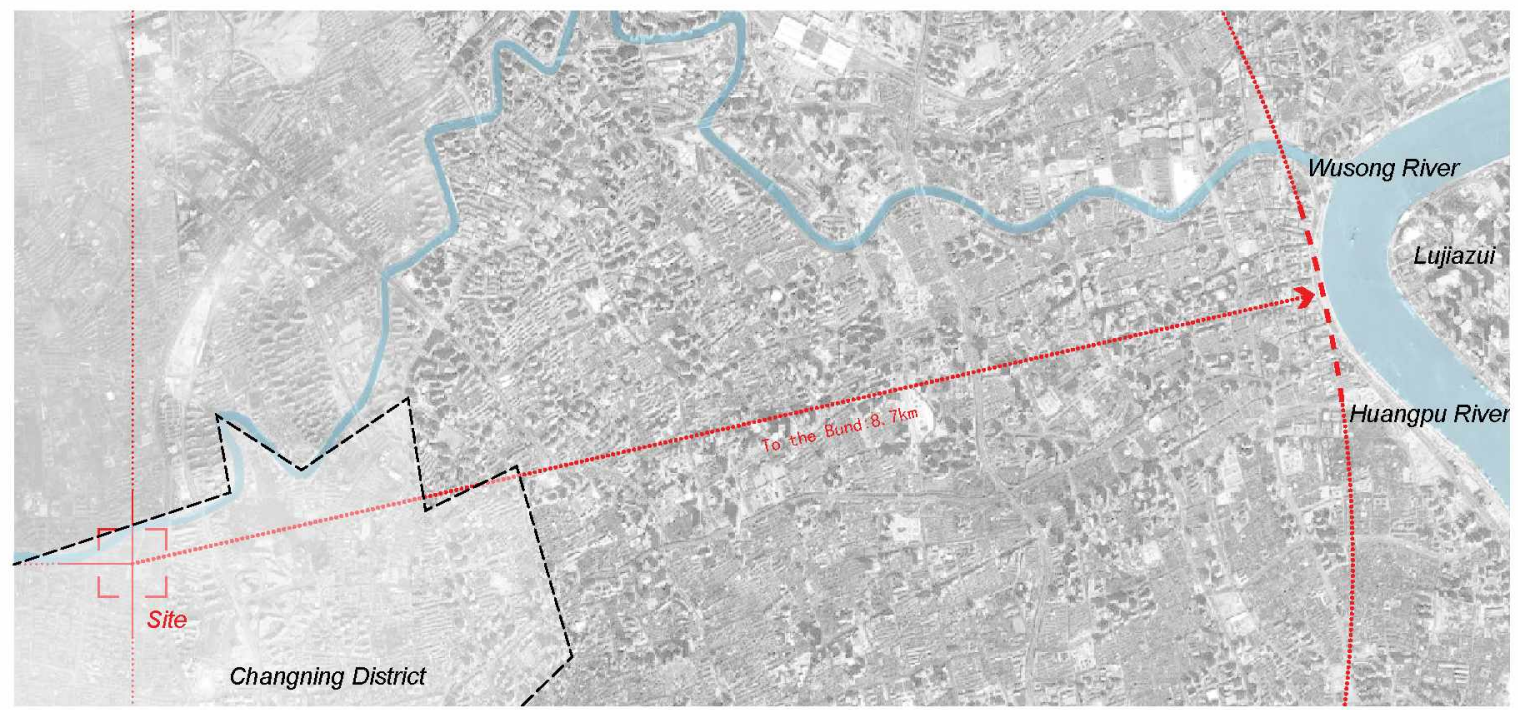

Fig 3.3 In Relation to the Bund and the Huangpu River 
Bordered by the Suzhou Creek to the north and the Inner Ring Elevated Rd. to the east, the 20-acre (8-hectare) parcel is surrounded to the south and west by multi-unit residential buildings of various heights from several different periods.

There are three types of housing in this area. The first, dating to the mid-twentieth century, is typically oneto three-storeys high and constructed of hollow clay tiles with sloped tile roofs. Much of what remains of this ad-hoc, self-built housing will likely be demolished because it lacks basic services. The second type of housing consists of rows of six- to seven-story walkups. Buildings of this kind usually belonged to work units and functioned as social housing for workers who were charged very little, if any, rent. A cross between barracks and Shanghai's traditional lilong housing, rows were typically organized east/west so that all units faced south. The third and final housing type consists of high-rise condominiums, typically thirteen or more stories tall. These apartments, constructed by privateor quasi-private-sector developers for the emerging middle-class, have sprouted across Shanghai in the past decade. Offering a higher standard of living, they feature elevators, south-facing balconies, and have been designed to minimize the impact of the ubiquitous air-conditioning units that festoon most residential 
buildings in China. Unlike high-rise housing in North America, floor plates are quite shallow and towers incorporate multiple cores so that all units have cross ventilation. Given the emphasis on orientation and access to sunlight in China, the taller the buildings the more widely they are spaced. Accordingly, complexes of high-rise condominiums are frequently organized around large, landscaped mid-block spaces over underground parking. Like older forms of housing, these high-rise complexes are normally walled off from streets and entered through controlled access points.

East China Normal University and East China University of Politics and Law, located on the north side of the Suzhou Creek, are both a five-minute walk from the site, Zhongshan and Changfeng Parks are also nearby - situated to the east and northwest respectively. The site is a ten-minute walk from the Cloud Nine (a.k.a. Dragon's Dream) complex, comprised of a 58-story office tower with a multi-level grocery store and shopping mall at its base. This building, designed by Arquitectonica, is located at the Zhongshan Park subway stop, which is the closest stop to the site. 
Fig 3.4 Land Use Diagram




Fig 3.5 Looking North Up Zhongshan West Road on the Eastern Edge of the Site

Fig 3.6 The Suzhou Creek with the Site on the Right and MidRise Housing Across the River to the Left

Fig 3.7 Low-Rise Buildings to the North of the Footbridge

Fig 3.8 Typical High-Rise Condo Apartments

Fig 3.9 The Zhongshan Park Subway Station

Fig 3.10 The Footbridge Across the Suzhou Creek at the Northwest Corner of the Site

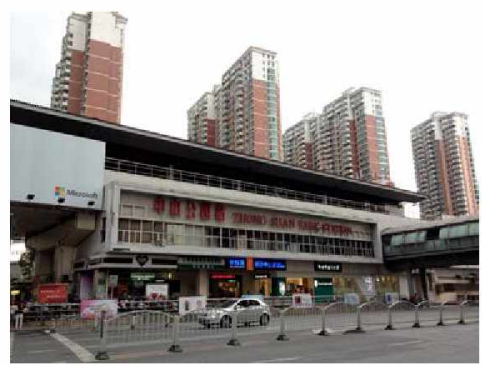

Fig 3.9

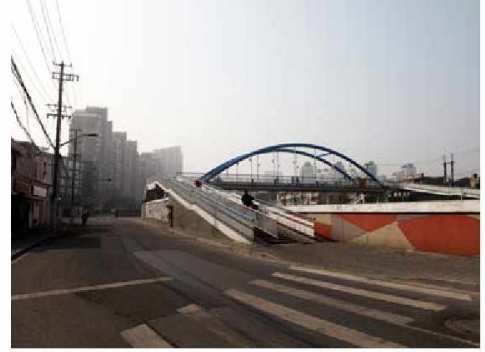

Fig 3.10



Fig 3.5

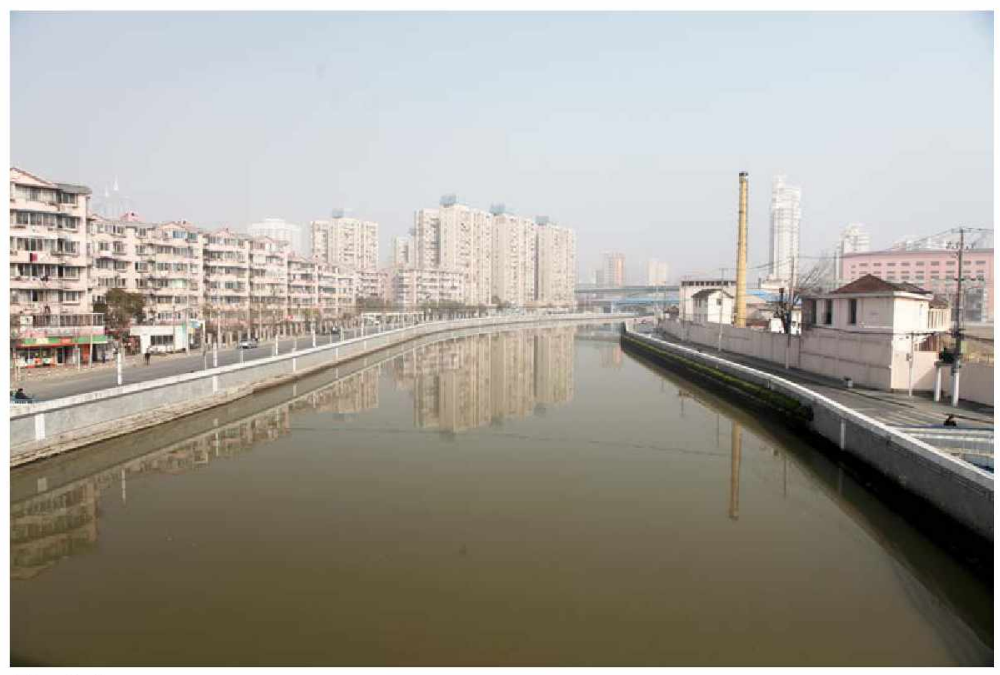

Fig 3.6



Fig 3.7

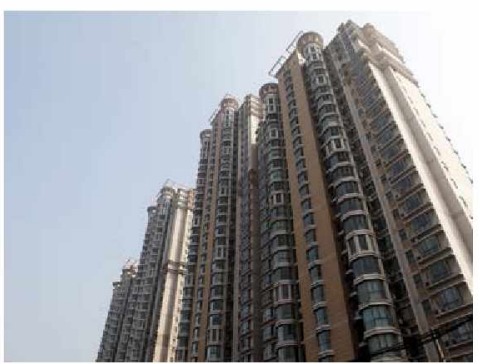

Fig 3.8 


\section{Circulation}

Completely enclosed by walls, the site has no connection to the urban context. It can be entered at two points: from Zhongshan West Road along the east side of the site and from Wanhangdu Rd., which separates the site from the river to the north. Circulation is a bit complicated along on the eastern edge of the site. Both the Inner Ring Elevated Rd. and Zhongshan West Road (which runs beneath it) cross the river at the northeast corner of the site. Because both are well above grade by the time they meet the river, an access road runs parallel to Zhongshan West Road along the eastern edge of the site. This oneway road connects with Wanhangdu Rd. at the river. Although walled off from it, no roads separate the site from the housing to the south and west.

Wanhangdu Rd. which separates the site from the river, turns south at the northwest corner of the site. A footbridge across the Suzhou Creek connects into Wanhangdu Rd. at this point. 
Fig 3.11 Existing Site Circulation

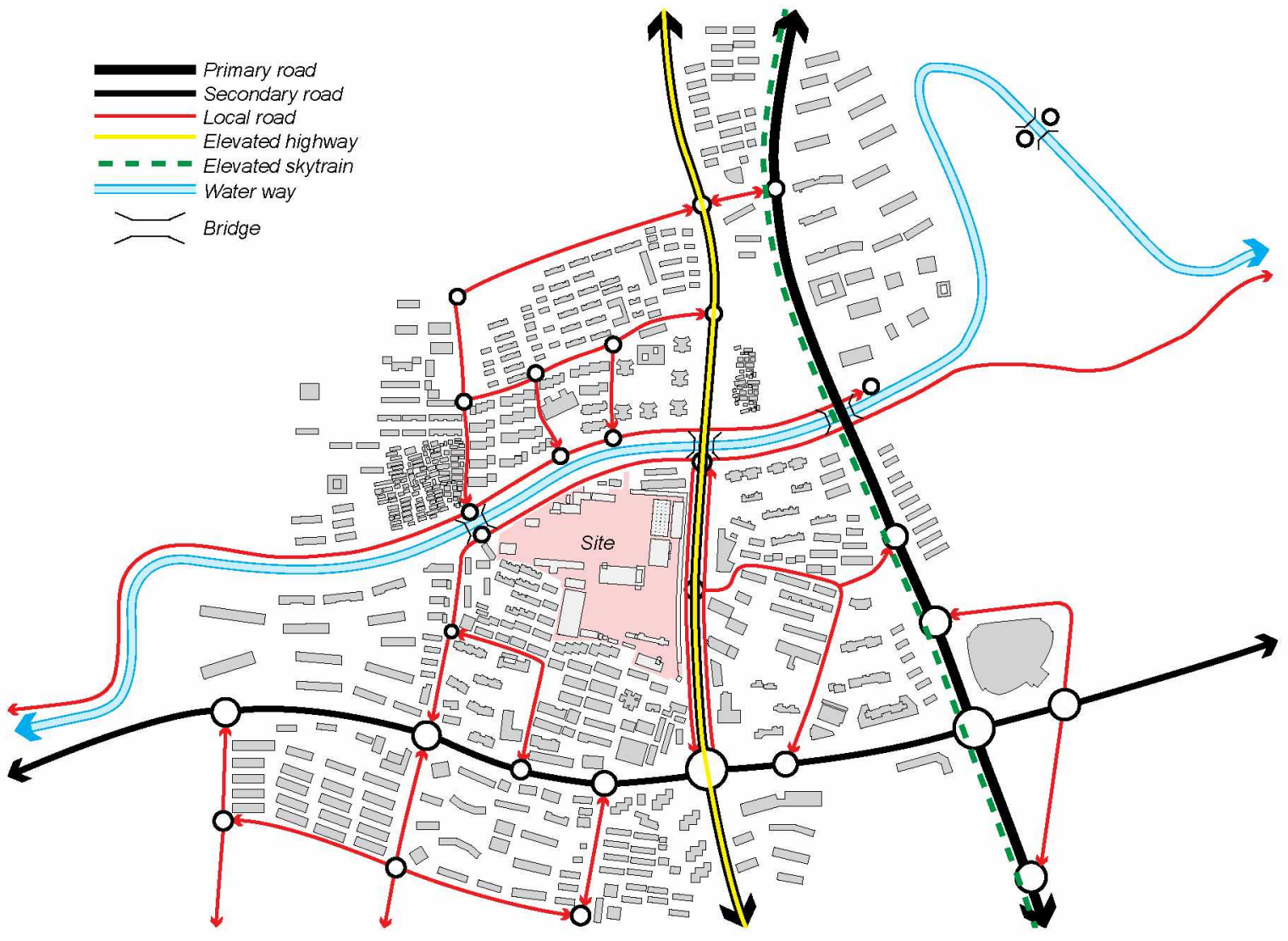




\section{Transportation}

The site is served by a variety of modes of transportation. There are several bus stops along the West Zhongshan Road and more along Changning Road, the primary road through the district, which runs parallel to the river about 500 meters to the south. Pedestrian traffic to the site would likely from the Zhongshan Park subway stop (up the access road along the eastern edge of the site) and via the footbridge to the northwest. The Zhongshan Park subway station is served by lines 2,3 , and 4 .

Fig 3.12 Transportation

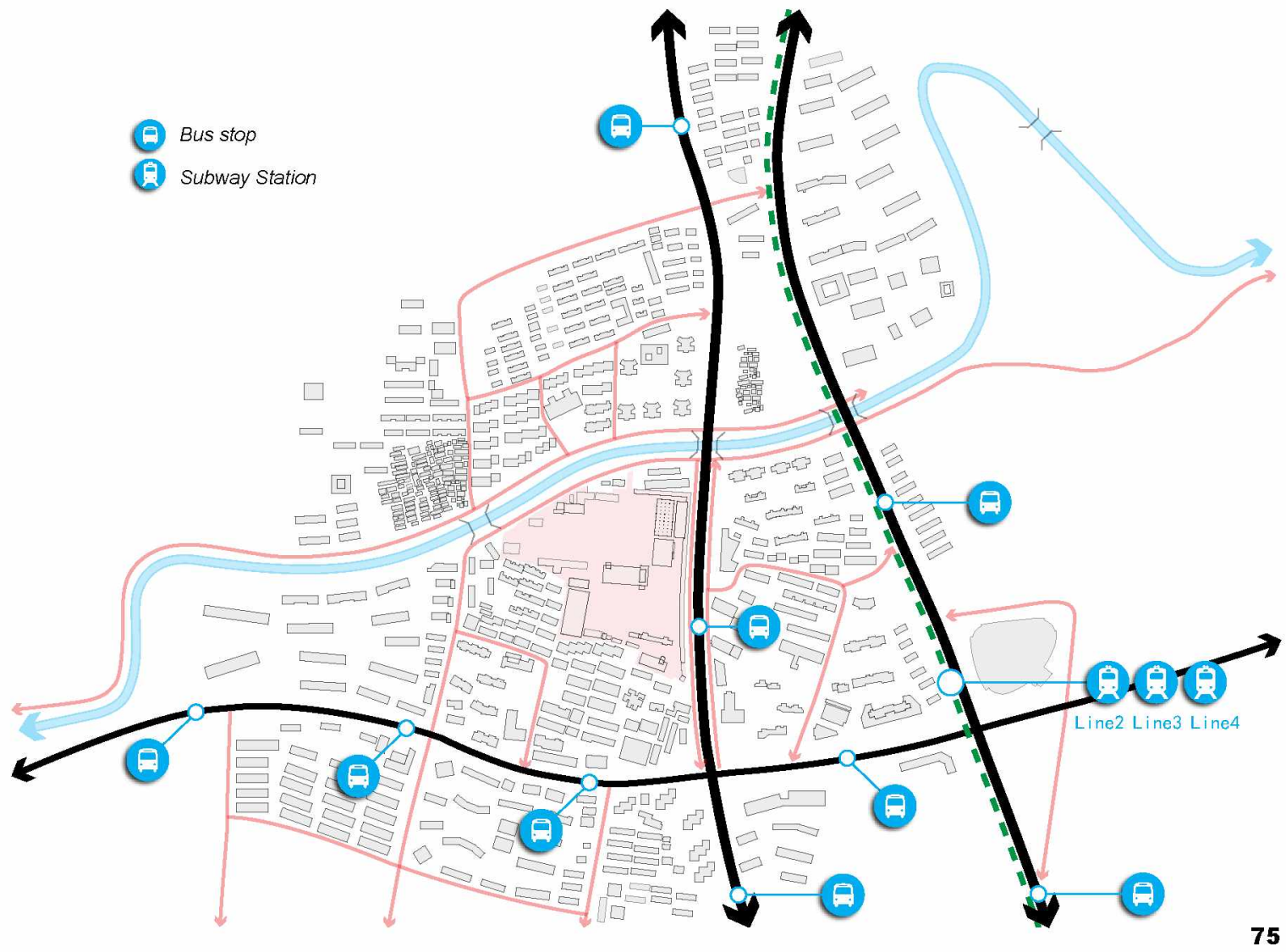




\section{Amenities}

Various services and amenities are within easy reach of the site, including a variety of restaurants and cafes. Being primarily residential in character, there are few office buildings in the area - with the notable exception of the Cloud Nine tower. The shopping mall in the base of the tower is one of the largest in Shanghai and includes a large grocery store.

Fig 3.13 Amenities

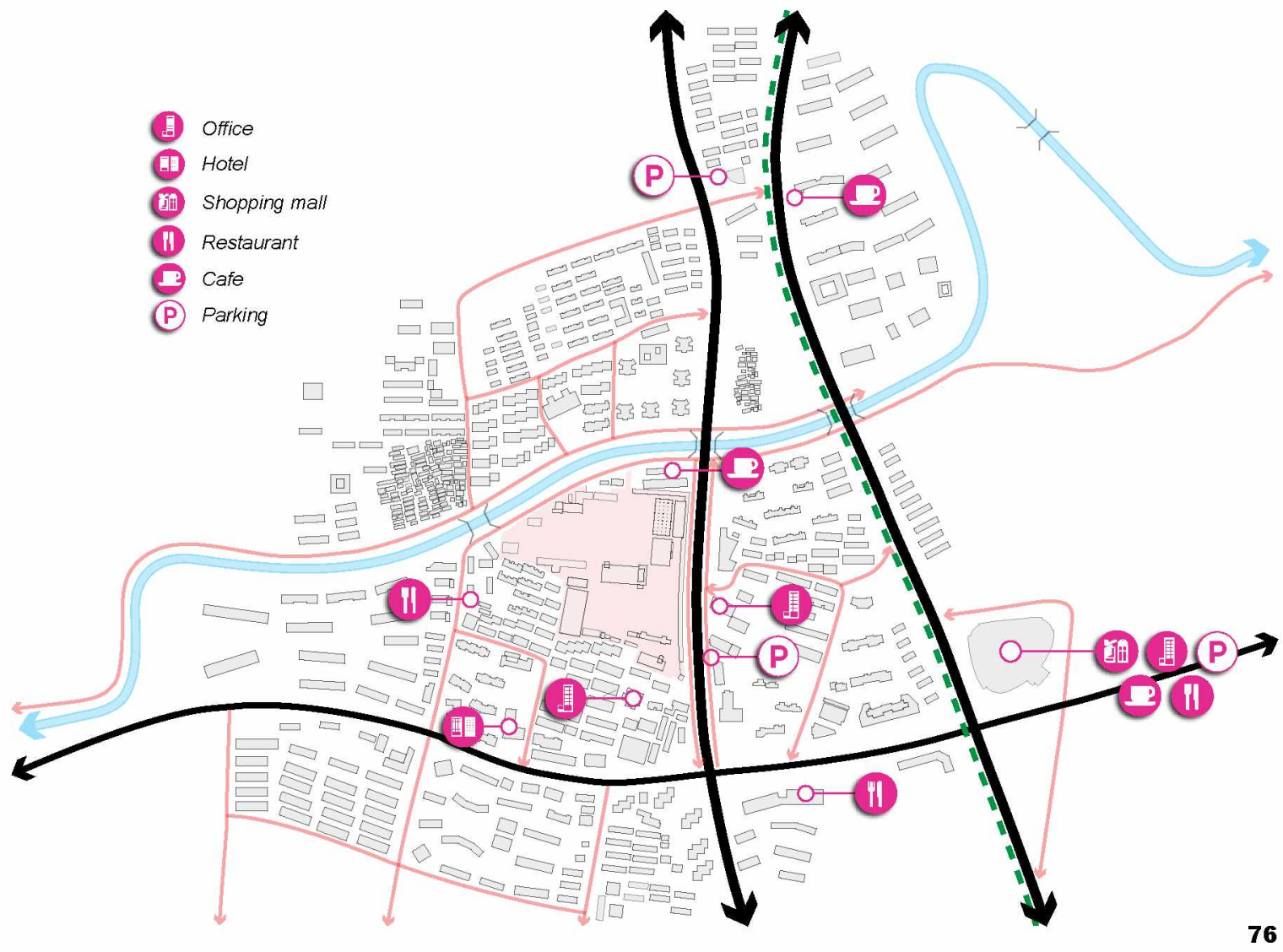




\section{Block Sizes}

As discussed in Chapter 2, city blocks in Shanghai are larger than those in most North American cities. Small blocks near the site, for example, average about 2.3 hectares in area, medium blocks 6.7 hectares, and large blocks 16.8 hectares - about fifteen times the size of a typical New York City block. As they are typically under the control of a single entity (work unit or municipal government), redevelopment of Shanghai's urban fabric typically occurs in large chunks.

Fig 3.14 Block Size Diagram

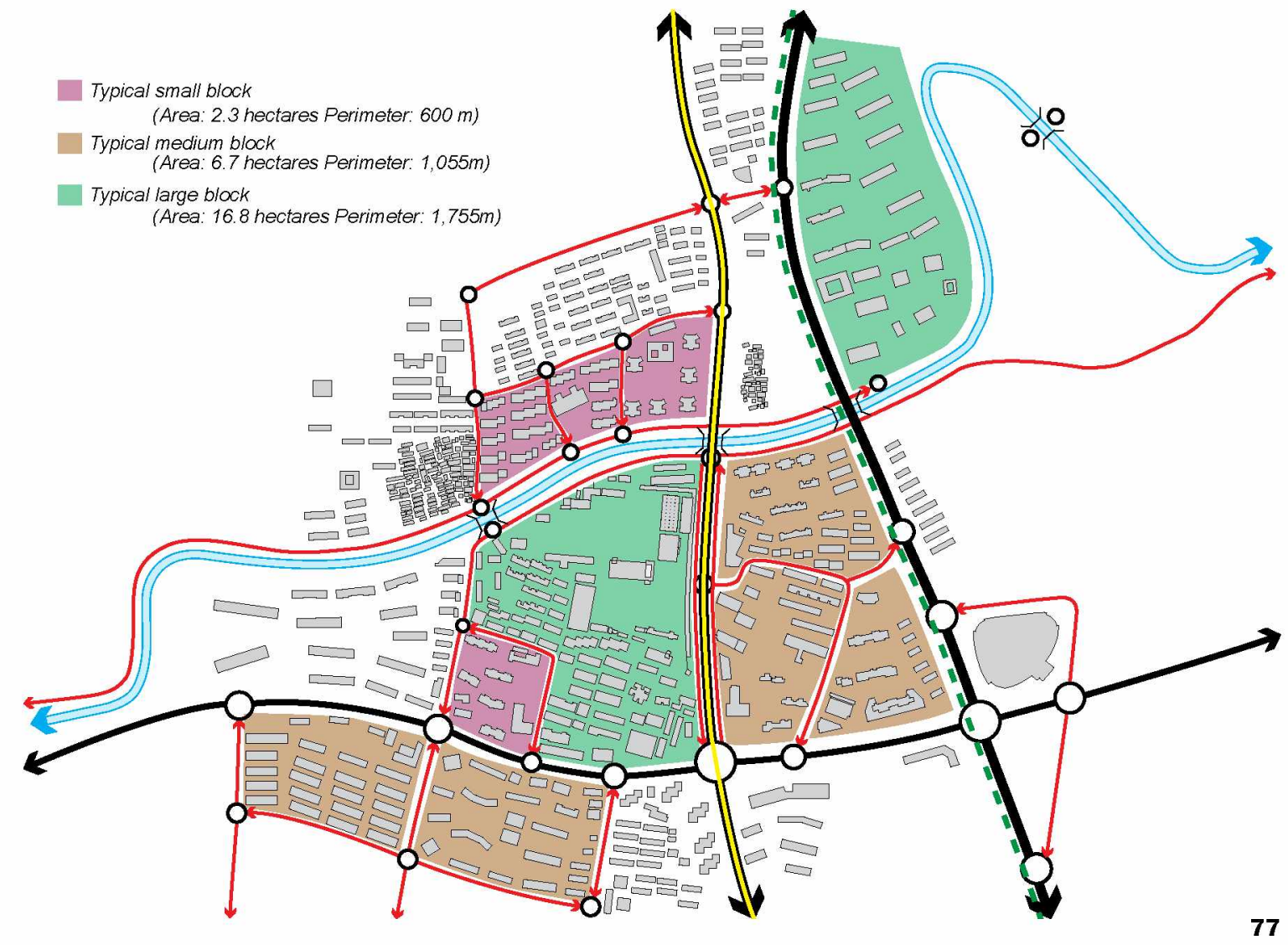




\section{Basic Site Information}

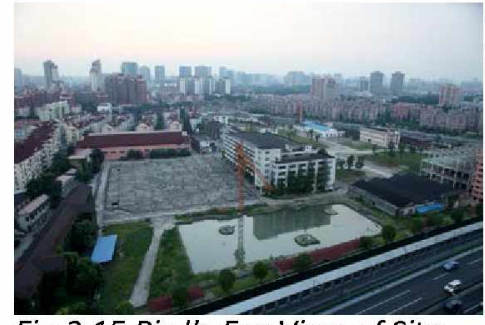

Fig 3.15 Bird's-Eye View of Site
The site has a total area of $82,255 \mathrm{~m}^{2}$ (8.2 ha. or 20.3 acres) and includes fourteen buildings, all of which are currently vacant. Together footprint of these buildings comprises $19,464 \mathrm{~m}^{2}$ or $23.7 \%$ of the site's area. In and among the buildings are three large open areas which, together account for another $32.7 \%$ of the site. The existing buildings are typical factory lofts/ warehouses with large, open interiors and high ceilings. Together the fourteen buildings comprise a total gross floor area (GFA) of $61,289 \mathrm{~m}^{2}$ at a relatively low floor area ratio (FAR) of 0.745 . Among the more interesting elements on the site are a large underground parking garage and an elevated pedestrian walkway planted with trees.

The one-story underground parking garage sits directly south of the largest building on the site. It has a footprint of $7,200 \mathrm{~m}^{2}$. Unlike other underground parking structures, a number of openings have been cut into it from the surface to permit sunlight to penetrate, and various freestanding staircases travel through these openings. Solid, 5-meter high concrete columns support the space, whose poured-in-place concrete walls are reminiscent of Louis Kahn's work at the Salk Institute. All of these characteristics suggest 
enormous potential for future development.

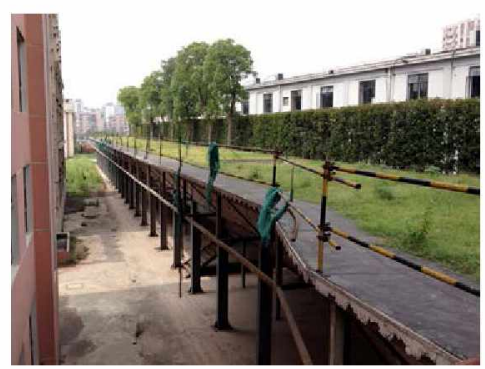

Fig 3.16 The Elevated Walkway

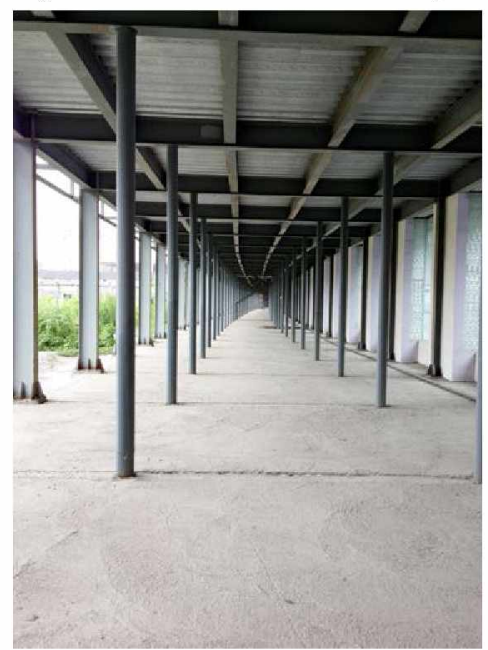

Fig 3.17 Underneath the Walkway
The elevated pedestrian walkway, located on the eastern edge of the site, is another unique feature. 5-meter tall columns support a 2-meter layer of soil in which a number of trees have been planted and on which a number of pavilions have been constructed connected by pathways. Glass panels shield the walkway, which sits above the level of the surrounding wall, from traffic noise generated by Inner Ring Elevated Road. The relatively thin steel columns supporting this structure, make it appear to float. Various staircases along its length give pedestrians the opportunity to circulate along it.

While it was not built to accommodate a rail line, the elevated walkway recalls the High Line in New York City, albeit smaller in scale. Being a unique and compelling feature, this element will be incorporated into the redeveloped site. 


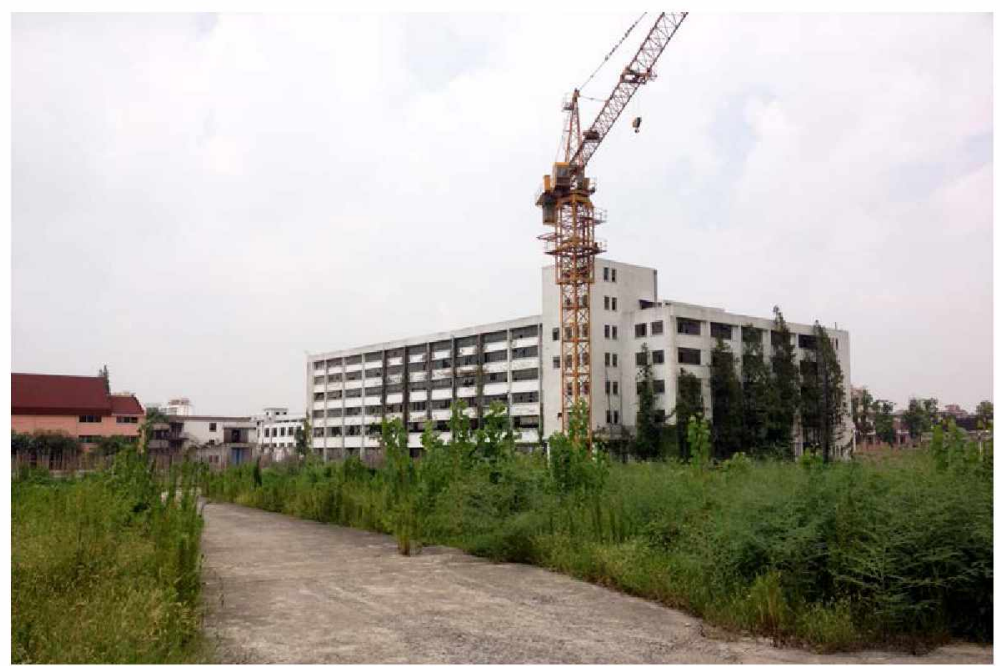

Fig 3.18

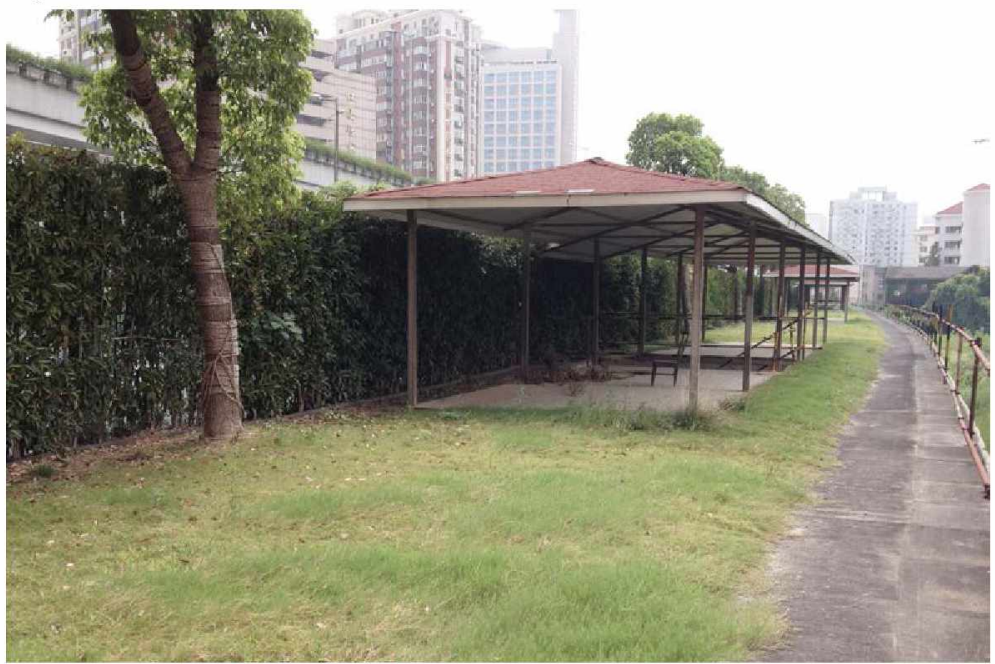

Fig 3.19

Fig 3.18 Building 14

Fig 3.19 Pavilions Along the Elevated Walkway

Fig 3.20 Staircase Leading to the Elevated Walkway

Fig 3.21 Entrance to the Underground Parking Garage

Fig 3.22 Parking Garage Interior 1

Fig 3.23 Parking Garage Interior 2

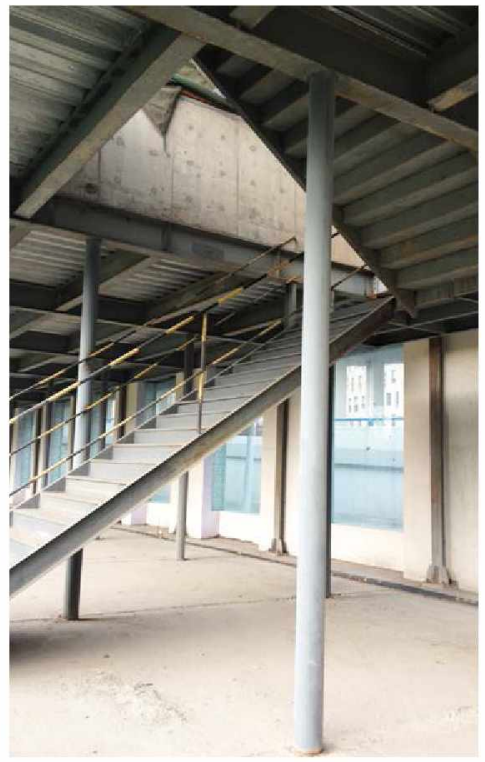

Fig 3.20

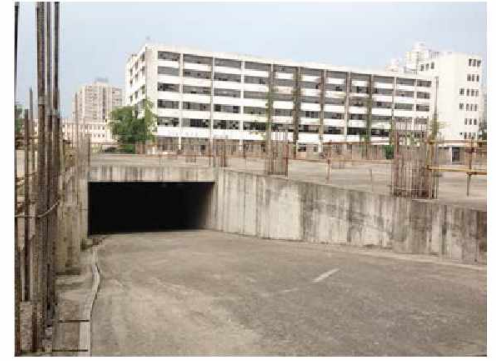

Fig 3.21

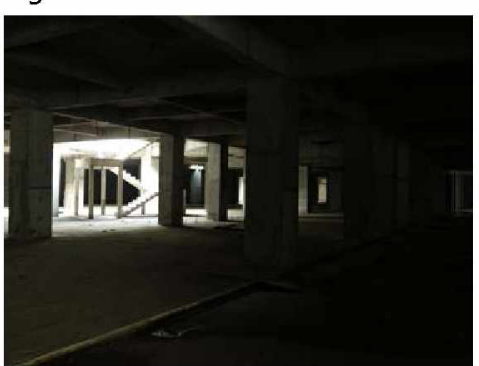

Fig 3.22

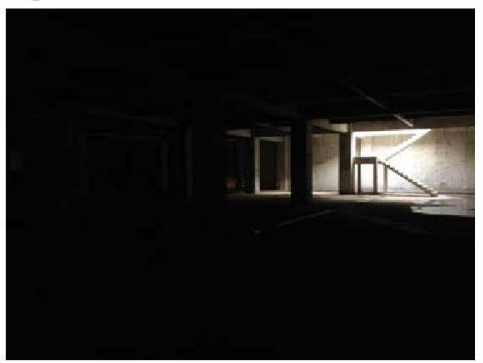

Fig 3.23 


\section{Building Rating System}

Given the square footage targets set for the redevelopment and the desire to introduce circulation through the site, it seemed unlikely that all of the existing buildings could be retained. Accordingly it was necessary to formulate criteria by which to make decisions. The rating system devised uses eight indicators namely, Exterior Condition, Interior Condition, Floor to Floor Clearance, Building Height, Building Location, Special Architectural Features, Gross Floor Area, and Typical Floor Area. ${ }^{1}$ Points from each factor contributed to a total score for each building; the higher the score, the greater chance that the building would be retained. While the assessment, like the system itself, is largely subjective it was meant to provide an informed basis for decision-making. 

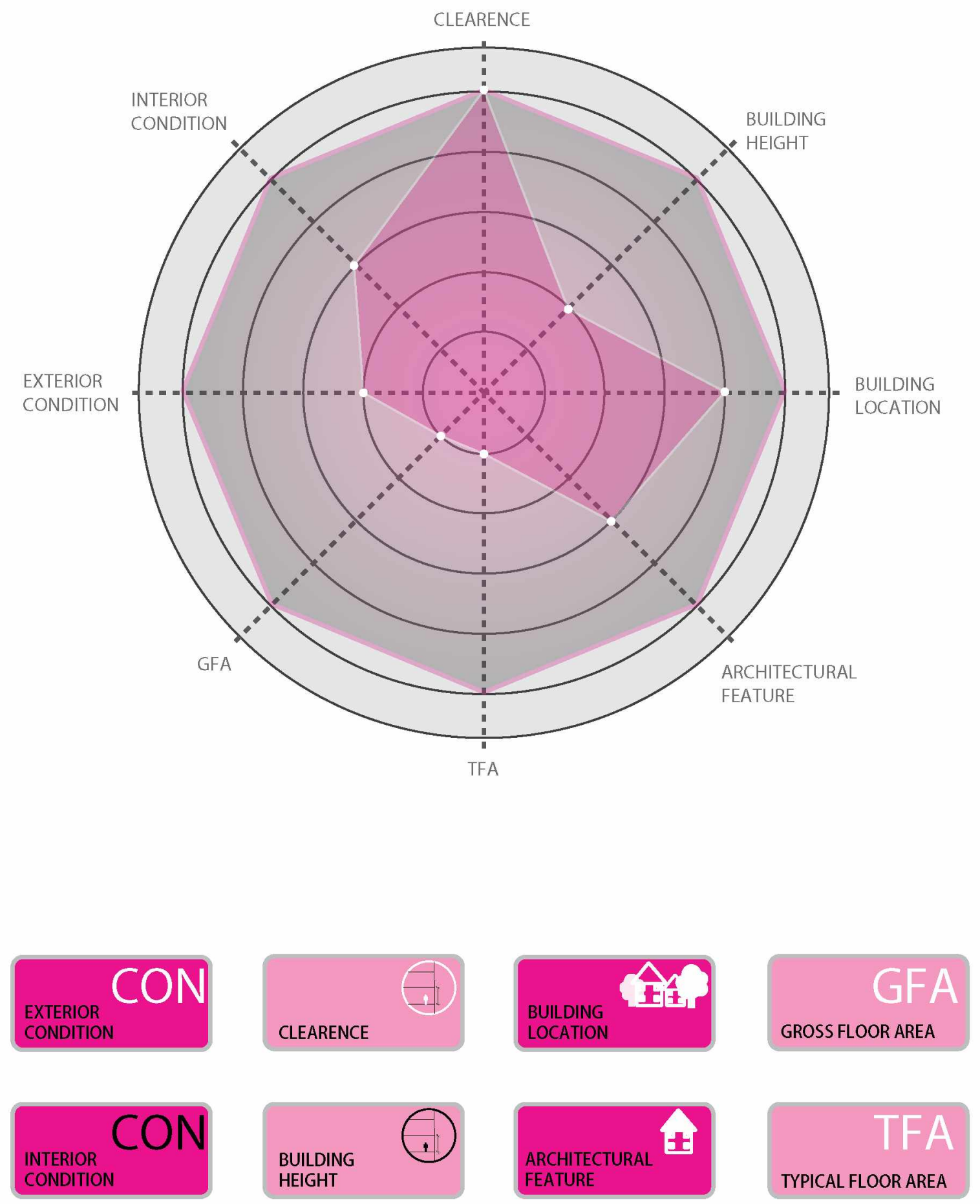


\section{Building 1}



Building 2



\section{Building 3}

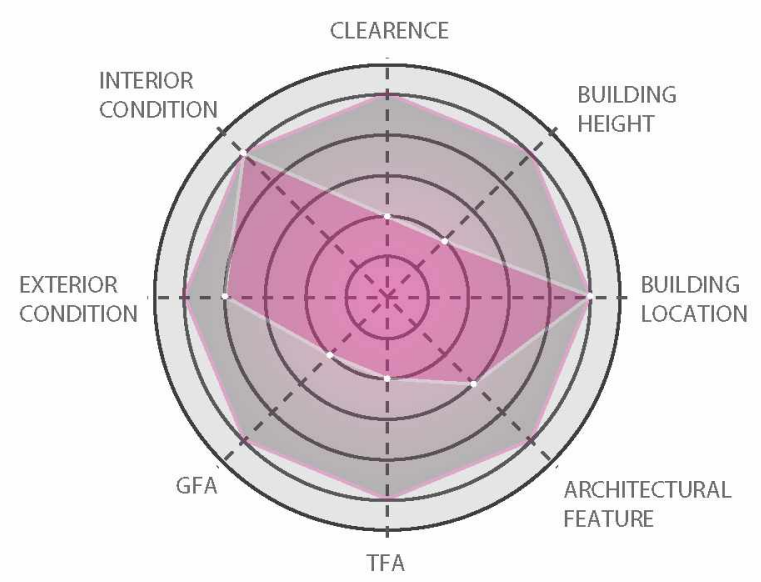

Fig 3.25 Building Inventory 1

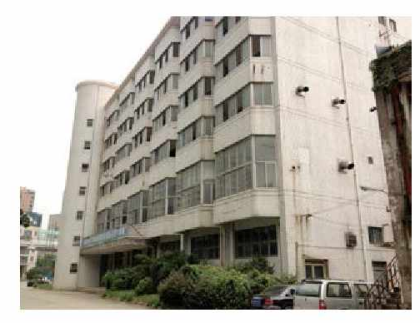

TFA:1,325 m2 Number of Floors:6 GFA:7,950 m2
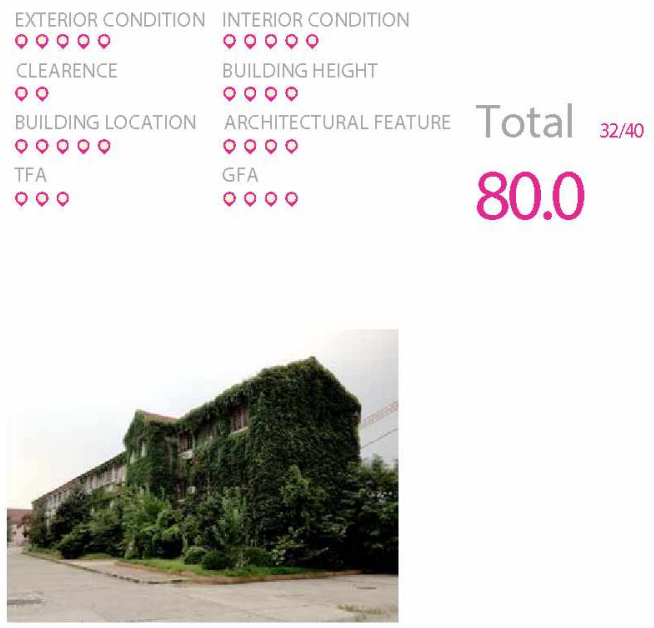

TFA:816 m2 Number of Floors:3 GFA:2,448 m2



\section{Building 4}

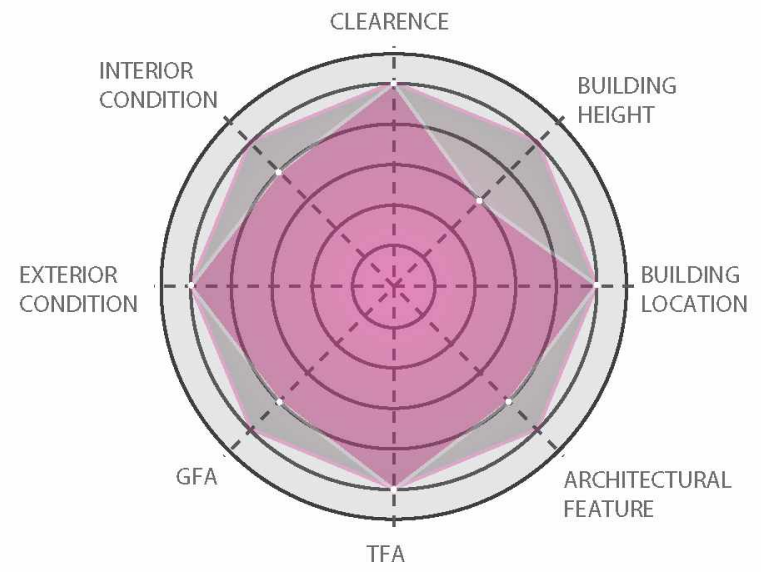

\section{Building 5}



\section{Building 6}

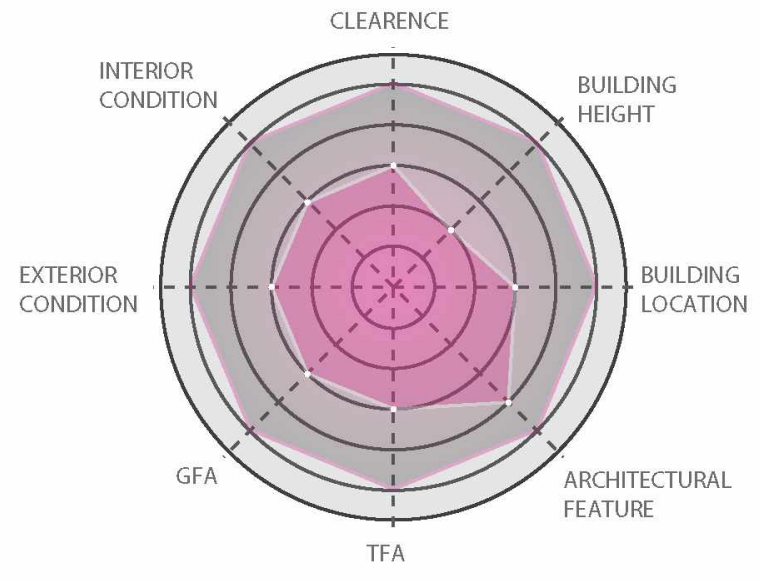

Fig 3.26 Building Inventory 2

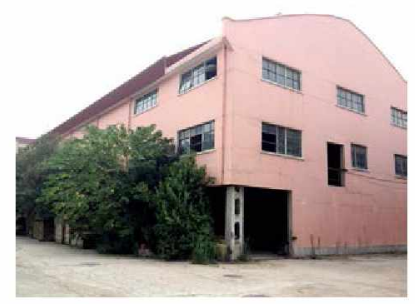

TFA:3,252 m2 Number of Floors:2 GFA:6,504 m2
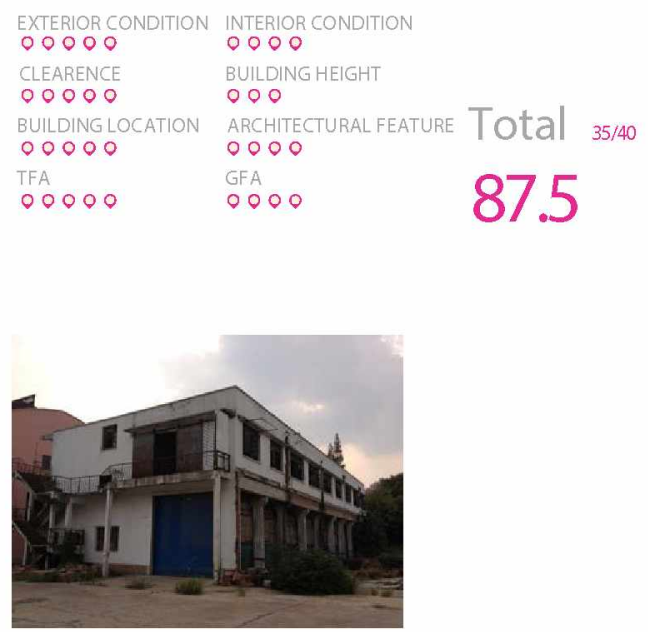

\section{TFA:574 m2 Number of Floors:2 GFA:1,148 m2}
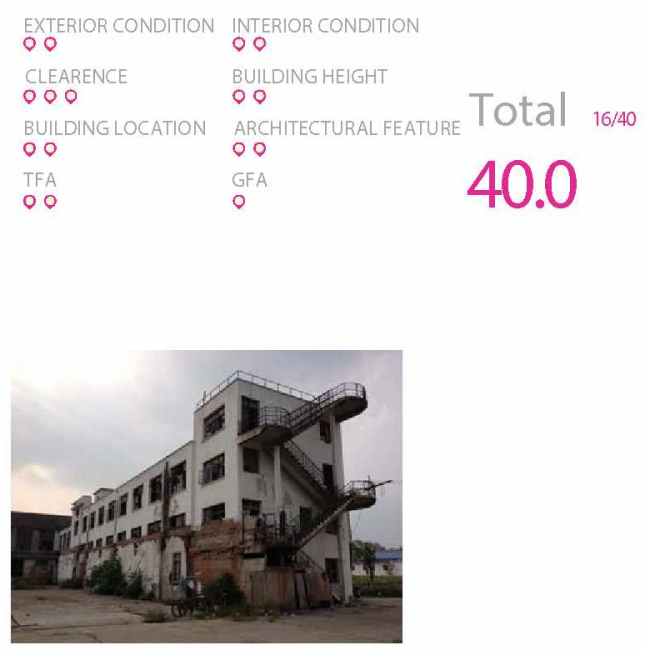

TFA:1,486 m2 Number of Floors:3 GFA:4,458 m2

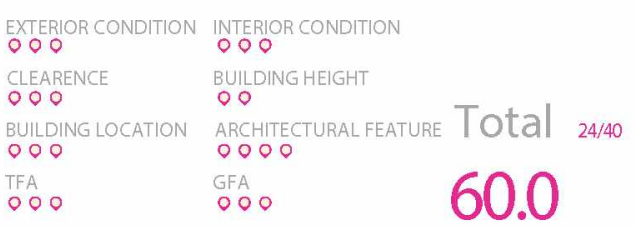




\section{Building 7}

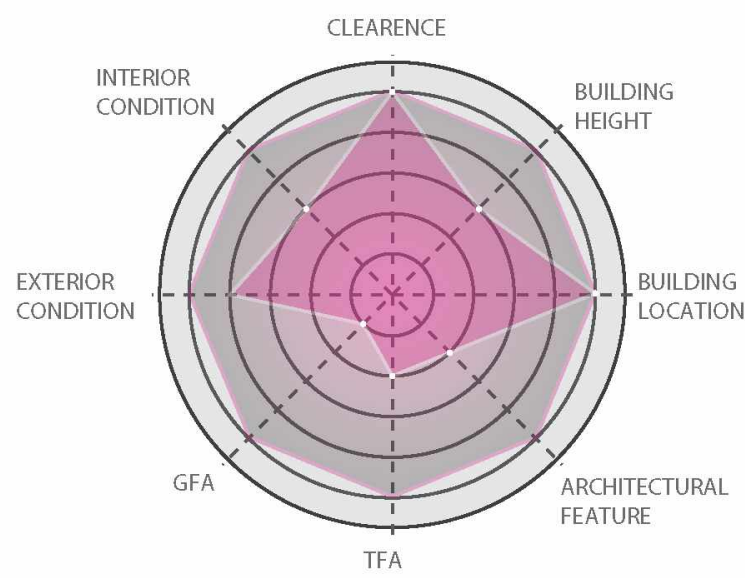

\section{Building 8}

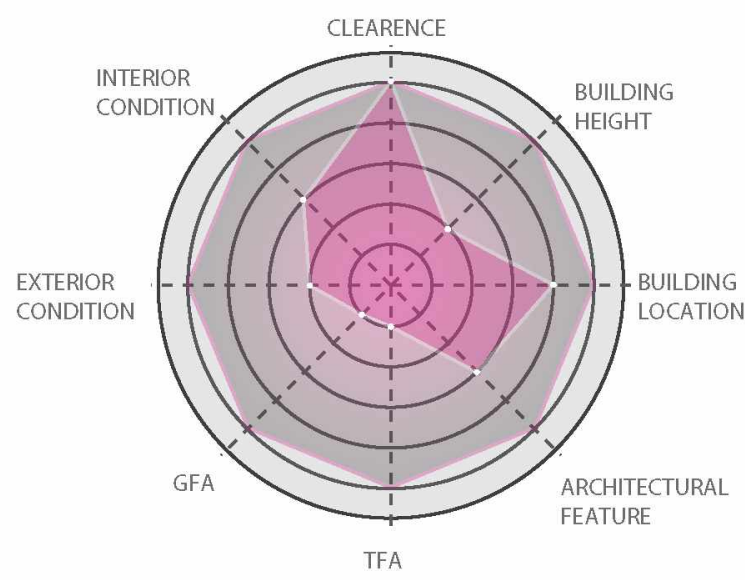

\section{Building 9}

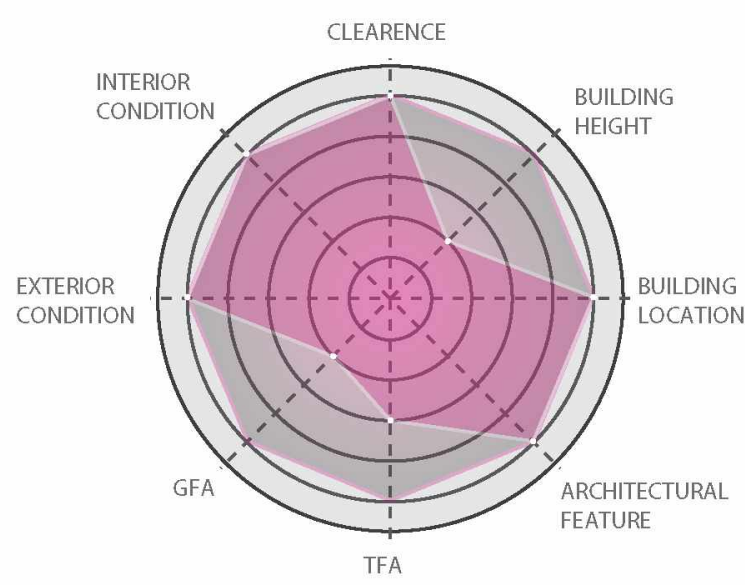

Fig 3.27 Building Inventory 3


TFA:1,536 m2 Number of Floors: 1 GFA:1,536 m2

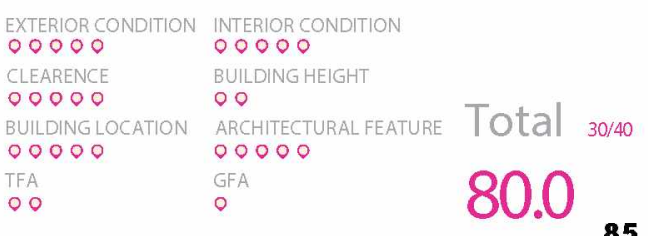




\section{Building 10}

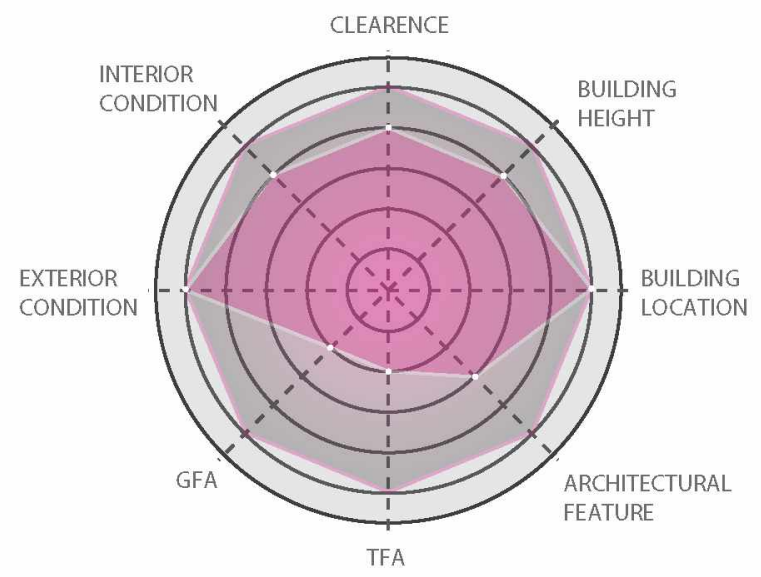

\section{Building 11}

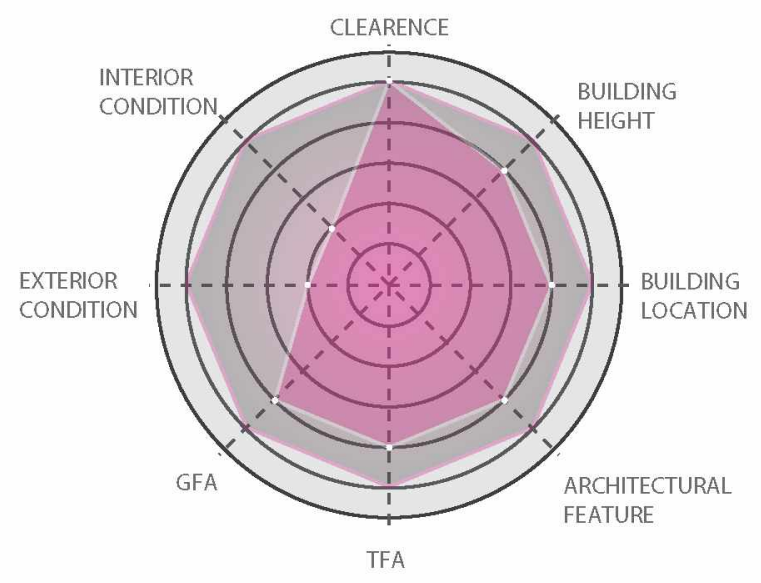

\section{Building 12}

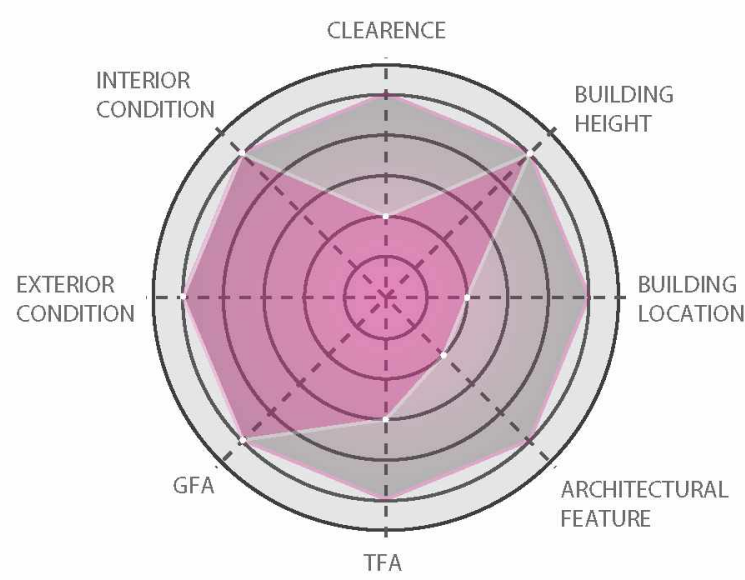

Fig 3.28 Building Inventory 4
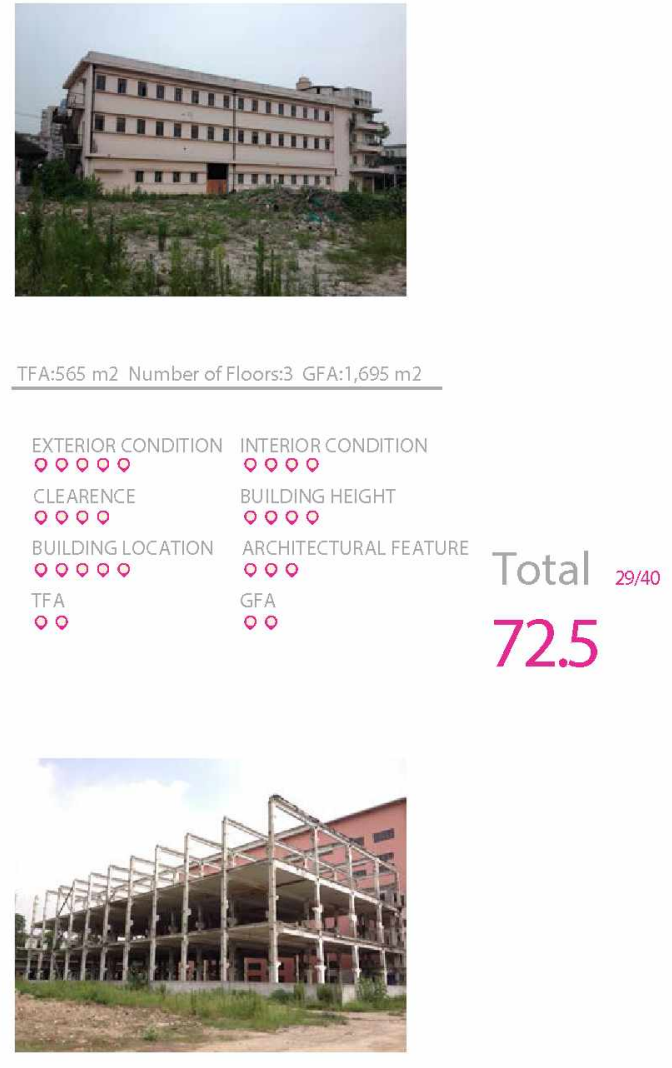

$\underline{\text { TFA:2, } 156 \mathrm{~m} 2 \text { Number of Floors:3 GFA:6,468 m2 }}$


TFA:1,437 m2 Number of Floors:10 GFA:14,370 m2

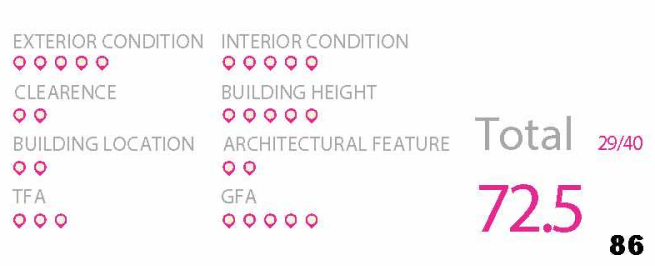




\section{Building 13}

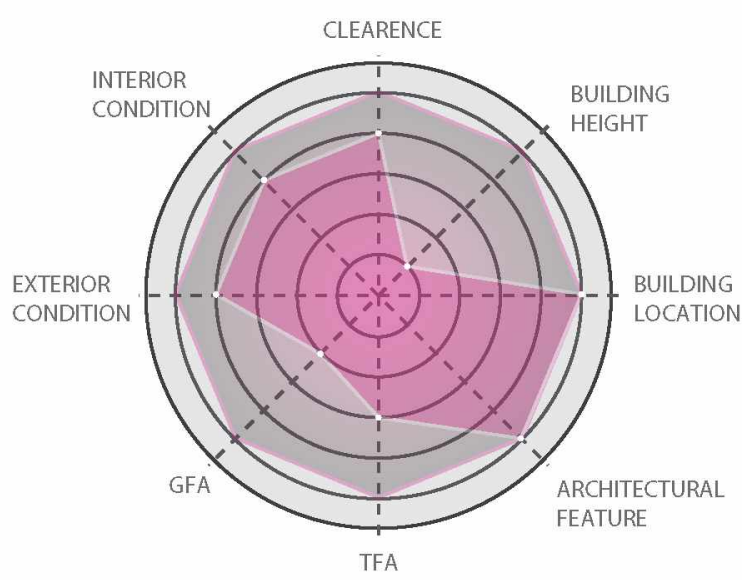

\section{Building 14}

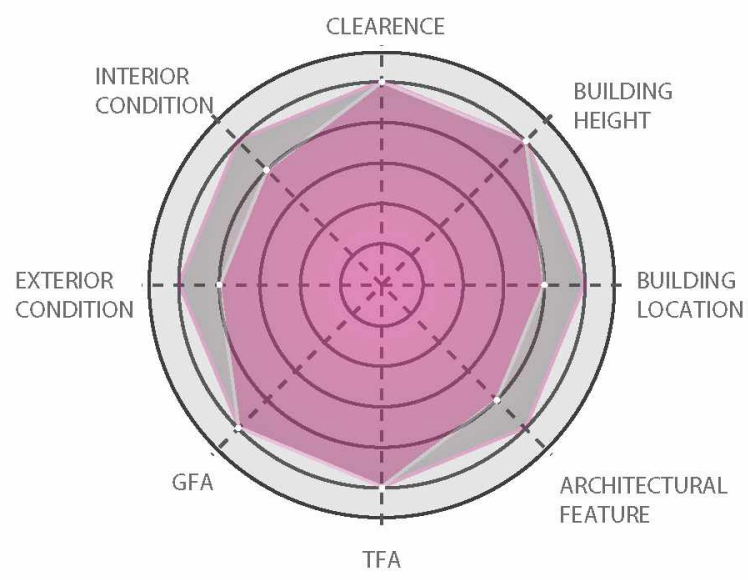

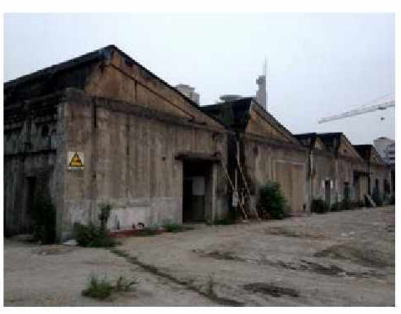

TFA:1,639 m2 Number of Floors:1 GFA:1,639 m2
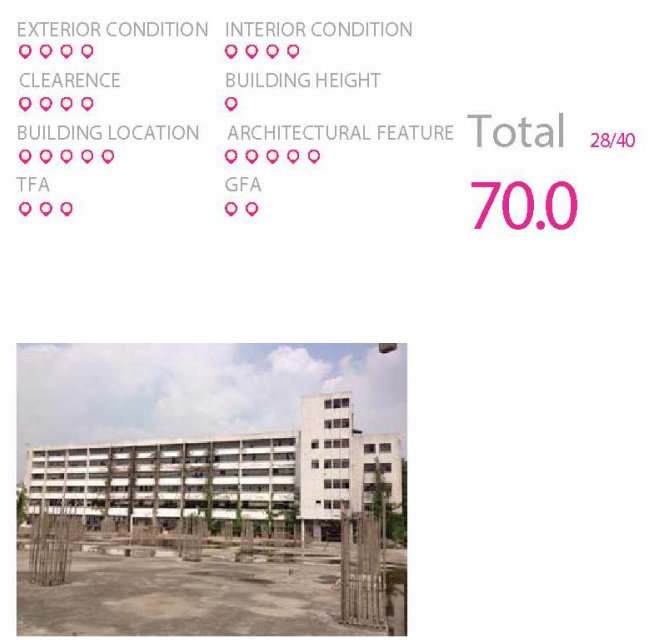

TFA:2,918 m2 Number of Floors:3 GFA:8,754 m2

$\begin{array}{ll}\text { EXTERIOR CONDITION } & \text { INTERIOR CONDITION } \\ 0000 & 0000 \\ \text { CLEARENCE } & \text { BUILDING HEIGHT } \\ 00000 & 00000 \\ \text { BUILDINGLOCATION } & \text { ARCHITECTURALFEATURE TOtal } 36 / 40 \\ 0000 & 0000 \\ \text { TFA } & \text { GFA } \\ 00000 & 00000\end{array}$




\section{Six Experimental Design Proposals}

\section{Program}

Given the focus on mixed-use development, I identified five different programs to integrate on the site: office space, commercial/retail, housing, recreational space (leveraging the recreational potential of the river), and institutional usages. For the purposes of this exercise I assumed institutional uses might be associated with the China Normal University, a ten-minute walk north of the site across the Suzhou River. The next step was to determine how much of each category of program to integrate, where it should be located, and what form it might take.

\section{In Search of a Structure and Strategy}

Several different permutations (Options 1 through 6) were explored to better understand the site and assess how much program it might be able to accommodate. At issue was a target of high FAR and the need to overlay the site with a new network of vehicular and pedestrian circulation. Another key consideration 
was the desire to retain existing buildings wherever possible, especially those that ranked high in the rating matrix.

Where FAR is concerned, I set a target of between $200,000 \mathrm{~m}^{2}$ and $300,000 \mathrm{~m}^{2}$. The various design permutations helped me to assess trade-offs between density, open space, building form and the overall character and legibility of the site. The need for a new circulation network reflects the desire to open the site to a broader range of uses and users. And given the potential for the site to be a confusing jumble of new and existing buildings - a function of the its irregular shape and the somewhat ad-hoc configuration of existing buildings - it was important to impose a structure that was as legible as it was functional. To this end I extended additional "fingers" from the elevated walkway into the site and carved similar fingers into the site from the river to bring water into the complex. Together this grid of "fingers" created an overall grid of parcels into which to organize buildings.

Finally, it was important to leave large areas of the site open, acknowledging that (among other things) portions of the site had been designated as parkland. 
While the more obvious choice would have been to situate most of this along the river's edge, I opted for a different approach, namely more enclosed areas on either side of Building 14. I felt that open space might be more desirable in the center of the site than along the periphery.

Over the course of successive iterations I arrived at the following decisions, reflected in Option 6:

- A pair of office towers would be located close to the entrance to the site from Zhongshan West Access Rd. This would be convenient both for vehicular traffic and commuters arriving on foot from the Zhongshan Park subway stop.

- The main factory building (Building 14) located in the centre would be adapted for office usage and connected to the towers to form a new, L-shaped office precinct around the existing underground parking structure.

- Existing factory buildings south of the diagonal road through the site would be converted to institutional uses associated with the China Normal University. As this road connects directly to the footbridge across the river, buildings along this path would be easily accessible to students and faculty arriving on foot from the main campus to the north.

- The underground parking structure to the south 
of Building 14 would be adaptively transformed into a library for the University. The original idea was to leave the area above open as a planted quadrangle/park space separating the institutional from the business uses.

- A parallel open space would be developed on the north side of Building 14, separating the office uses from the housing precinct along the river.

- The existing industrial buildings at the northeast corner of the site would be repurposed for commercial uses.

- A recreation center - shared by the community and the university - would be located at the northwest corner of the site, adjacent to the footbridge.

- A series of residential slabs would be positioned close to the Suzhou River.

Option 6 resulted in an FAR of 3.48 and a gross floor area of $287,000 \mathrm{~m}^{2}$. It preserved seven of the fourteen existing buildings on the site, including Buildings 1 , 4, 9 and 14, which scored highest on the evaluation matrix. The distinctive elevated walkway along the eastern edge of the site was not only preserved, but was extended deeper into the site. All five target programs (office, institutional, residential commercial and recreational) were not only accommodated in the site, but organized into distinct precincts. 
Finally, a new road system was imposed on the site that, among other things, allowed for the rerouting of Wanhangdu Rd. so that the site had direct access to the river. The site can be entered at each of its three corners while a loop road within the site makes circulation flexible and intuitive. 


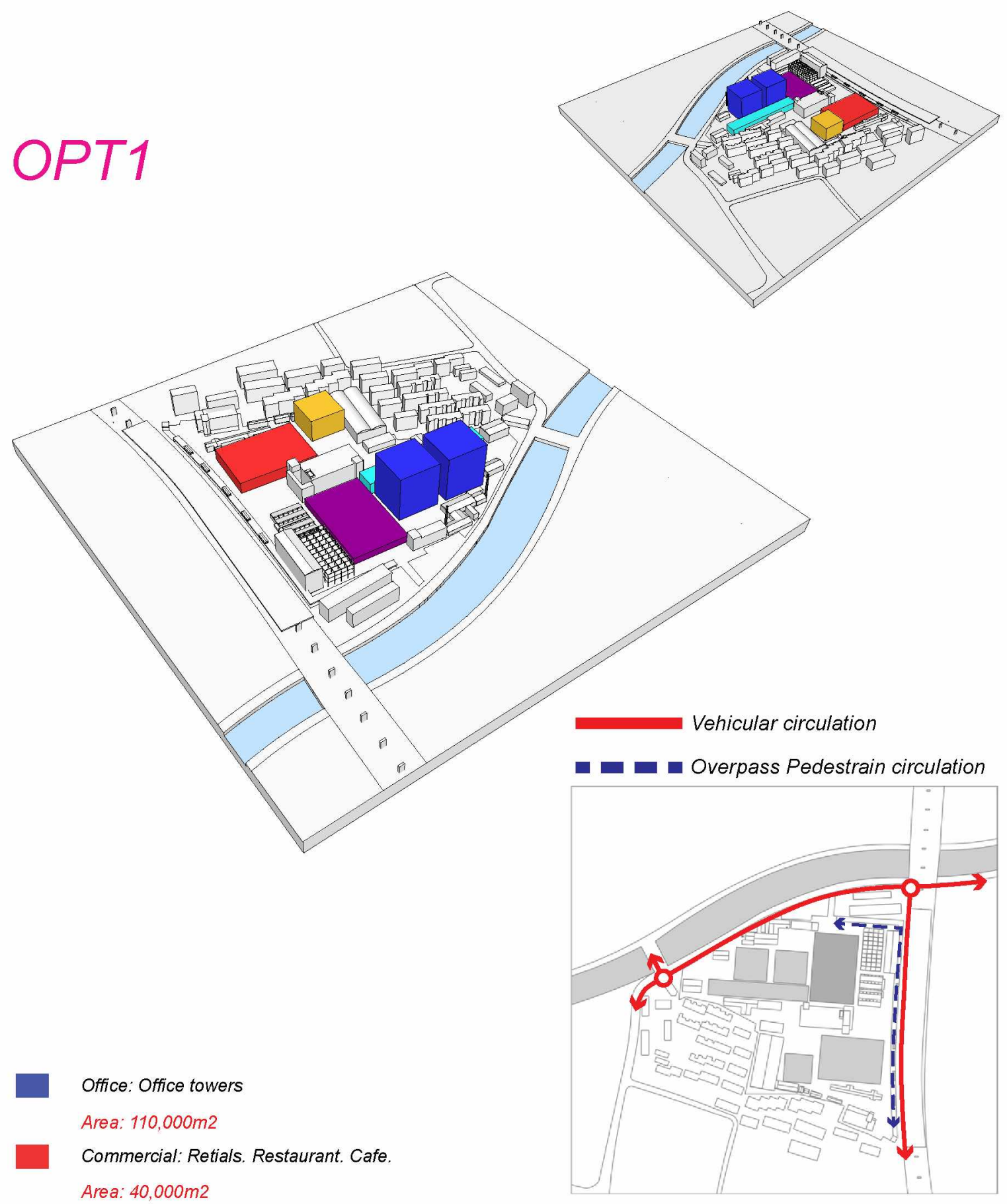
Area: $40,000 \mathrm{~m} 2$

Residential: Market housing. Residential for university students

Area: $20,000 \mathrm{~m} 2$

Recreational: Movie theater. GYM. Tennis court. Basketball court. Galleries. Sauna. Bar. Kayak Club Area: $24,000 \mathrm{~m} 2$

Institutional: laboratory. Kindergarden. Art studio

Area: $20,000 \mathrm{~m} 2$

GFA: $214,000 m 2$ Site area: $82,255 m 2$ FAR: 2.60

Fig 3.30 Design Approach Option 1 


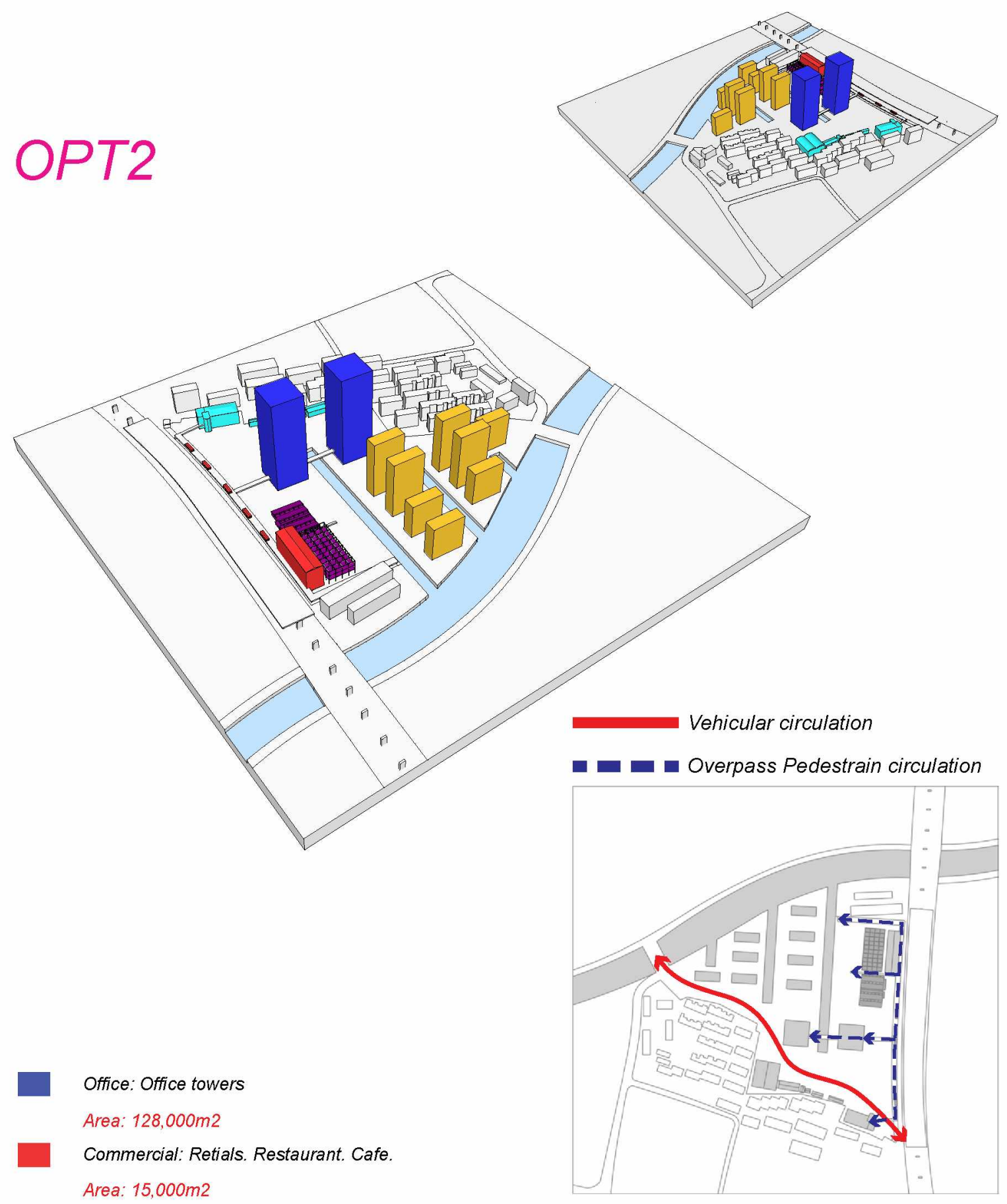

Area: $15,000 \mathrm{~m} 2$

Residential: Market housing. Residential for university students

Area: $96,000 \mathrm{~m} 2$

Recreational: Movie theater. GYM. Tennis court. Basketball court. Galleries. Sauna. Bar. Kayak Club

Area: $10,000 \mathrm{~m} 2$

Institutional: laboratory. Kindergarden. Art studio

Area: $17,000 \mathrm{~m} 2$

GFA: $266,000 m 2$ Site area: $82,255 m 2$ FAR: 3.23

Fig 3.31 Design Approach Option 2 


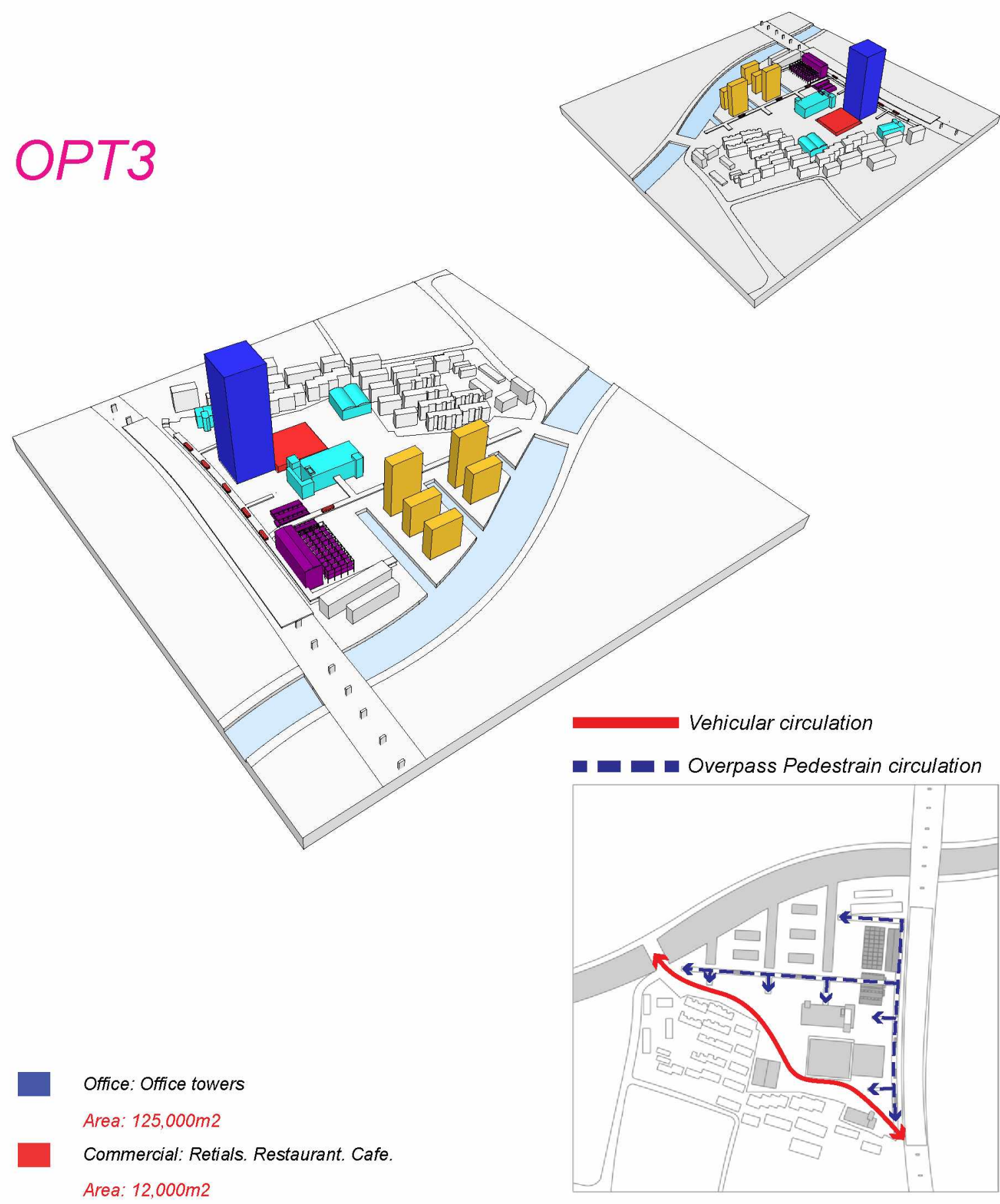

Area: $12,000 \mathrm{~m} 2$

Residential: Market housing. Residential for university students

Area: $57,000 \mathrm{~m} 2$

Recreational: Movie theater. GYM. Tennis court. Basketball court. Galleries. Sauna. Bar. Kayak Club

Area: $23,000 \mathrm{~m} 2$

Institutional: laboratory. Kindergarden. Art studio

Area: $20,000 \mathrm{~m} 2$

GFA: $237,000 m 2$ Site area: $82,255 m 2$ FAR: 2.88

Fig 3.32 Design Approach Option 3 


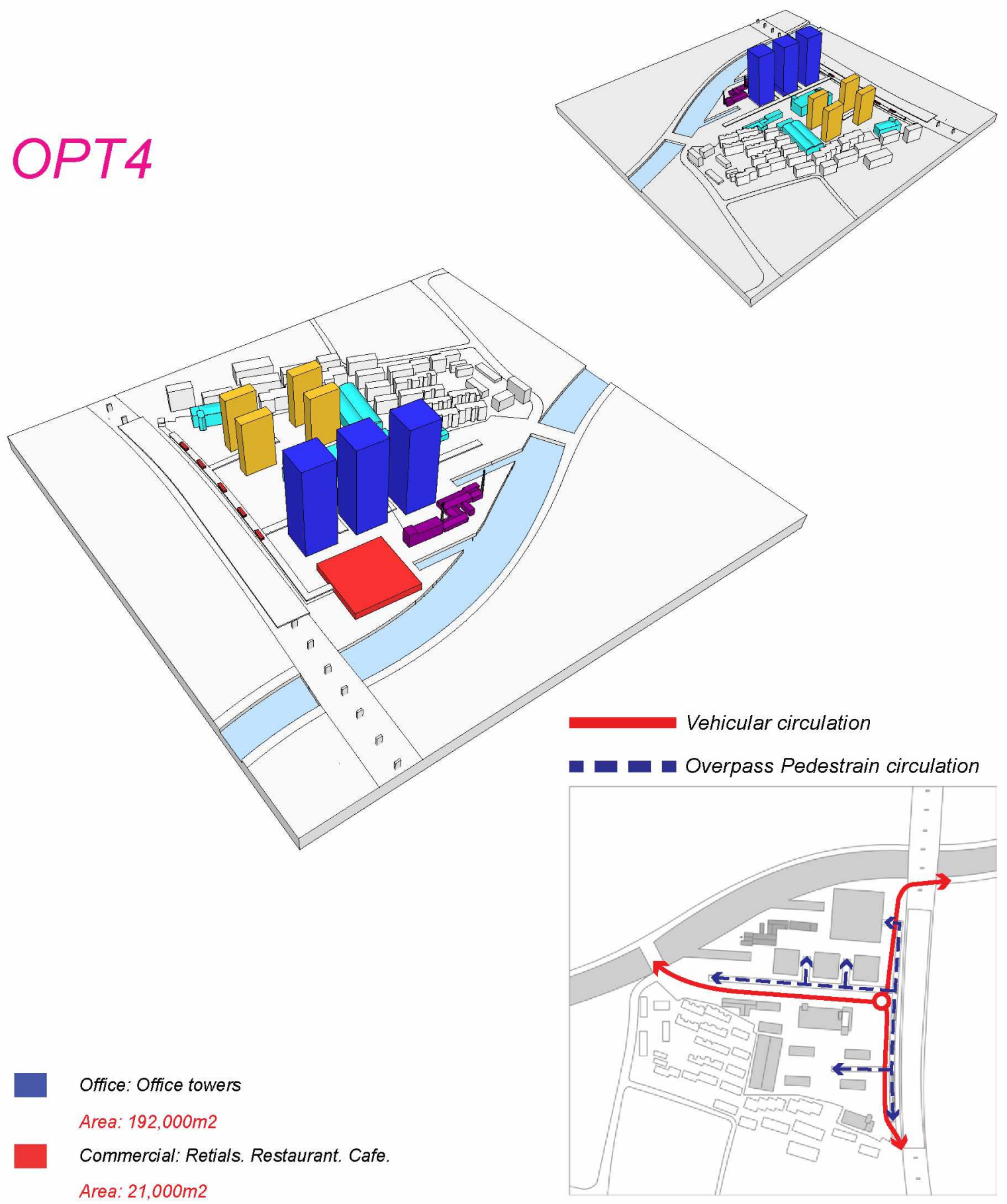
Area: $21,000 \mathrm{~m} 2$

Residential: Market housing. Residential for university students

Area: $60,000 \mathrm{~m} 2$

Recreational: Movie theater. GYM. Tennis court. Basketball court. Galleries. Sauna. Bar. Kayak Club Area: $4,000 \mathrm{~m} 2$

Institutional: laboratory. Kindergarden. Art studio

Area: $28,000 \mathrm{~m} 2$

GFA: $305,000 \mathrm{~m} 2$ Site area: $82,255 m 2$ FAR: 3.71

Fig 3.33 Design Approach Option 4 


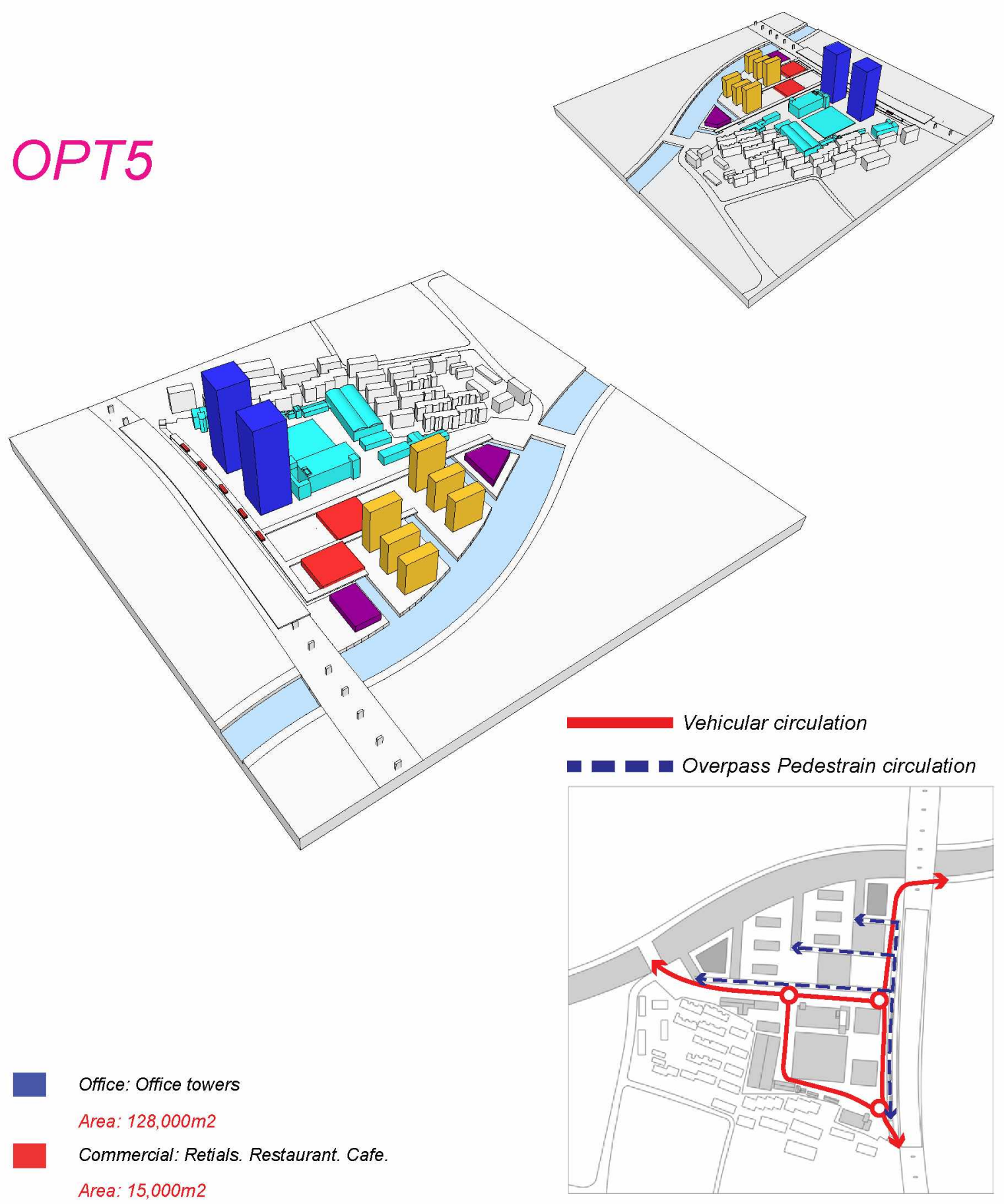

Area: 15,000m2

Residential: Market housing. Residential for university students

Area: 96,000m2

Recreational: Movie theater. GYM. Tennis court. Basketball court. Galleries. Sauna. Bar. Kayak Club

Area: $10,000 \mathrm{~m} 2$

Institutional: Jaboratory. Kindergarden. Art studio

Area: $38,000 \mathrm{~m} 2$

GFA: $287,000 m 2$ Site area: $82,255 m 2$ FAR: 3.48

Fig 3.34 Design Approach Option 5 


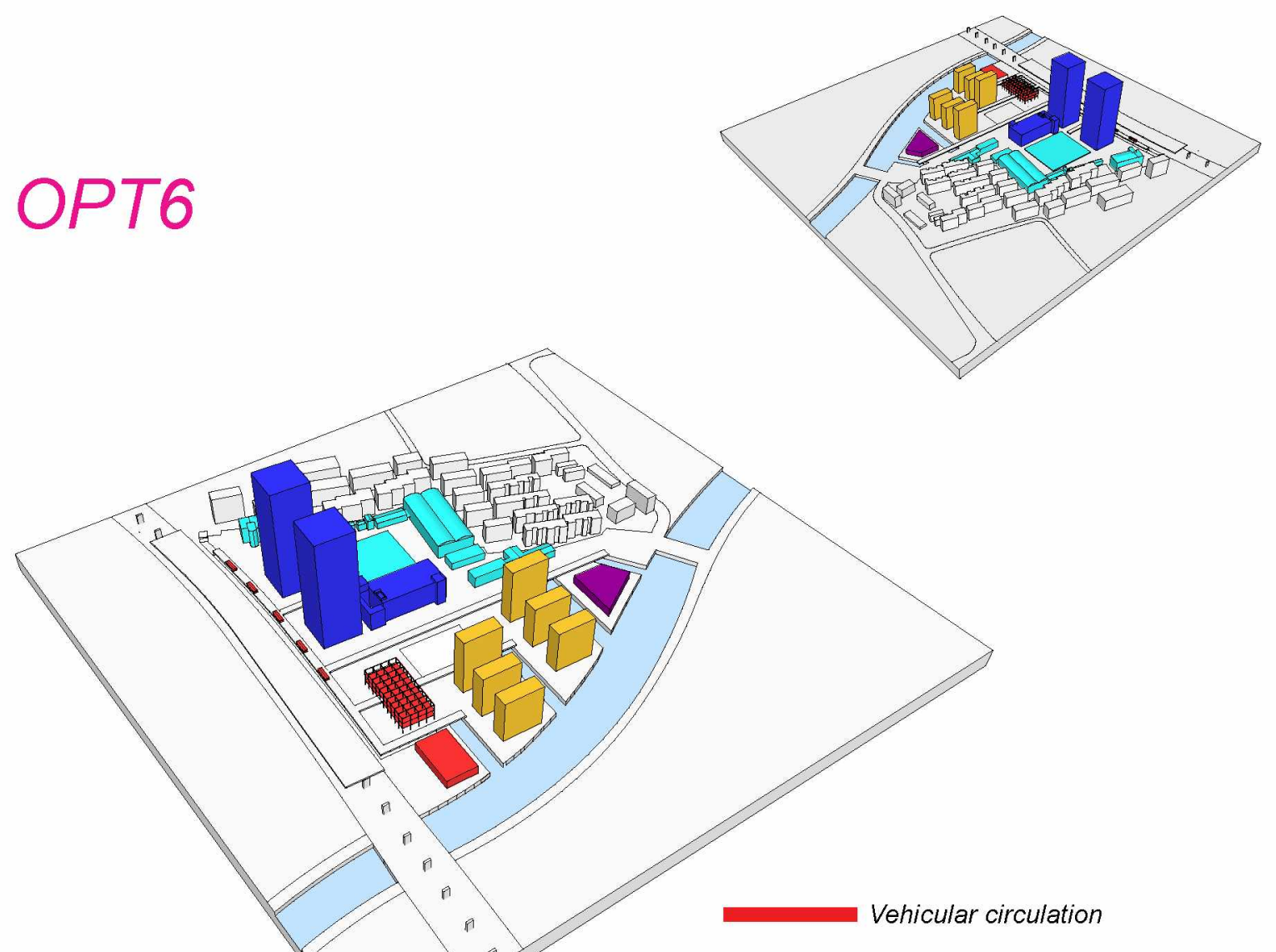

m $\boldsymbol{m}$ Overpass Pedestrain circulation

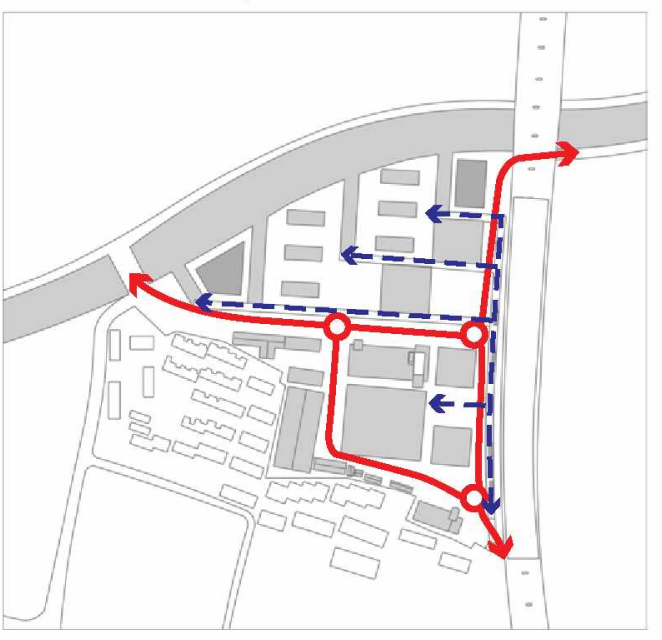

Office: Office towers

Area: $136,000 \mathrm{~m} 2$

Commercial: Retials. Restaurant. Cafe.

Area: $15,000 \mathrm{~m} 2$

Residential: Market housing. Residential for university students

Area: $96,000 \mathrm{~m} 2$

Recreational: Movie theater. GYM. Tennis court. Basketball court. Galleries. Sauna. Bar. Kayak Club

Area: $10,000 \mathrm{~m} 2$

Institutional: Iaboratory. Kindergarden. Art studio

Area: $30,000 \mathrm{~m} 2$

GFA: $287,000 m 2$ Site area: $82,255 m 2$ FAR: 3.48

Fig 3.35 Design Approach Option 6 


\section{Final Design Approach}

Having decided on a general strategy for the site, the next phase of design involved clarification and elaboration. Given the limitations of time, certain areas/issues received more attention than others. More time was devoted, for example, to the elevated walkway and the office precinct than other areas of the site.

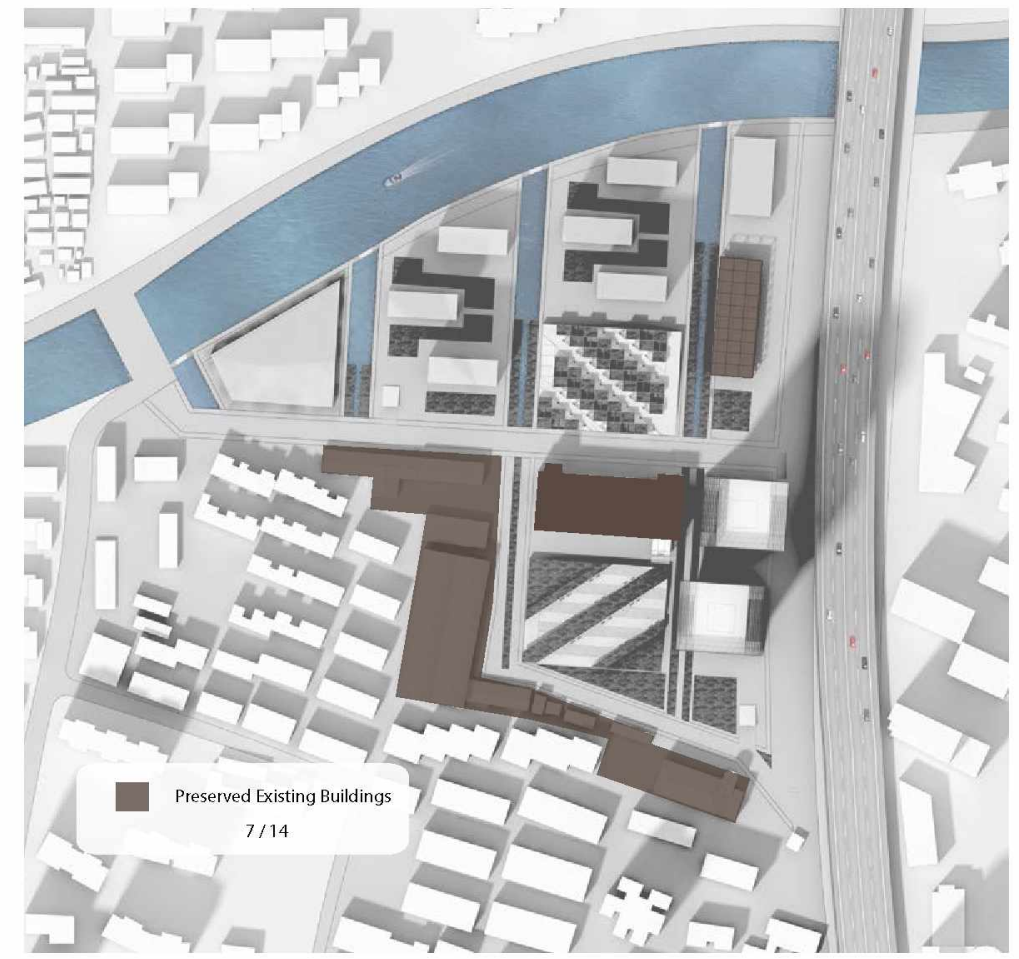

Fig 3.36 Existing buildings to be retained 


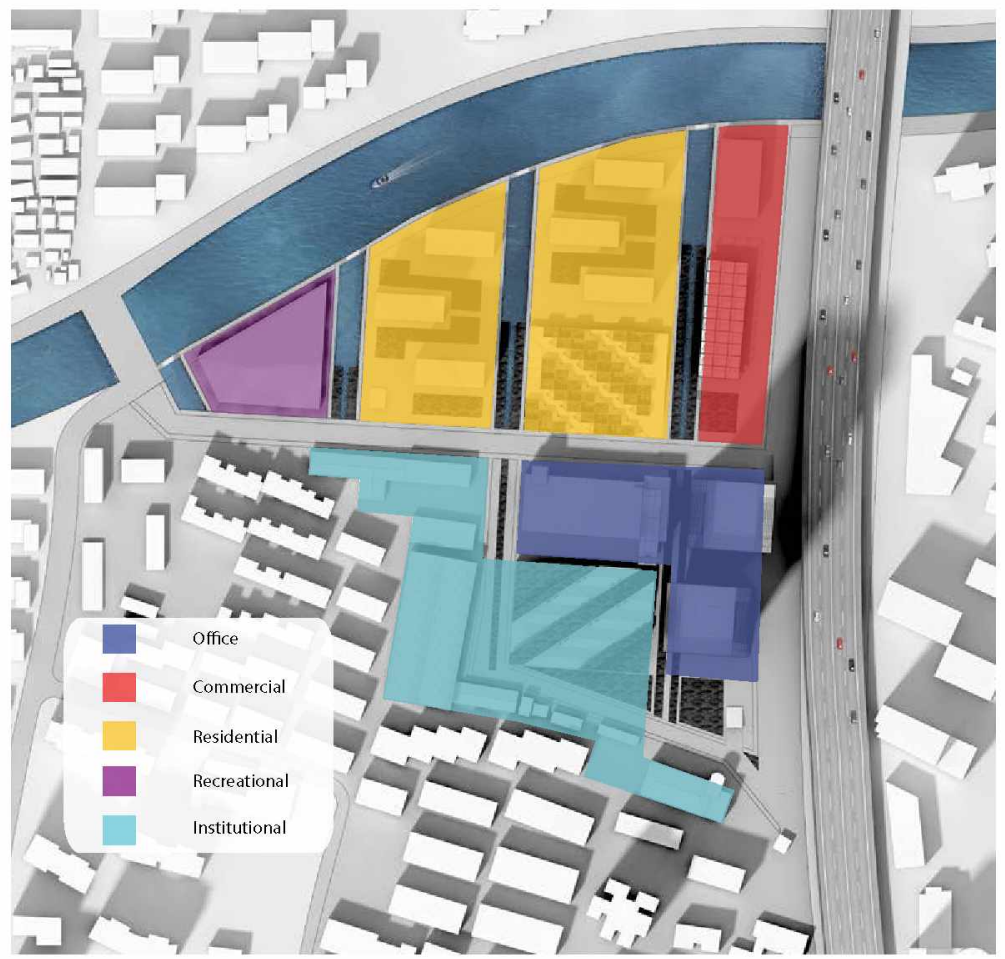

Fig 3.37 Five Programs

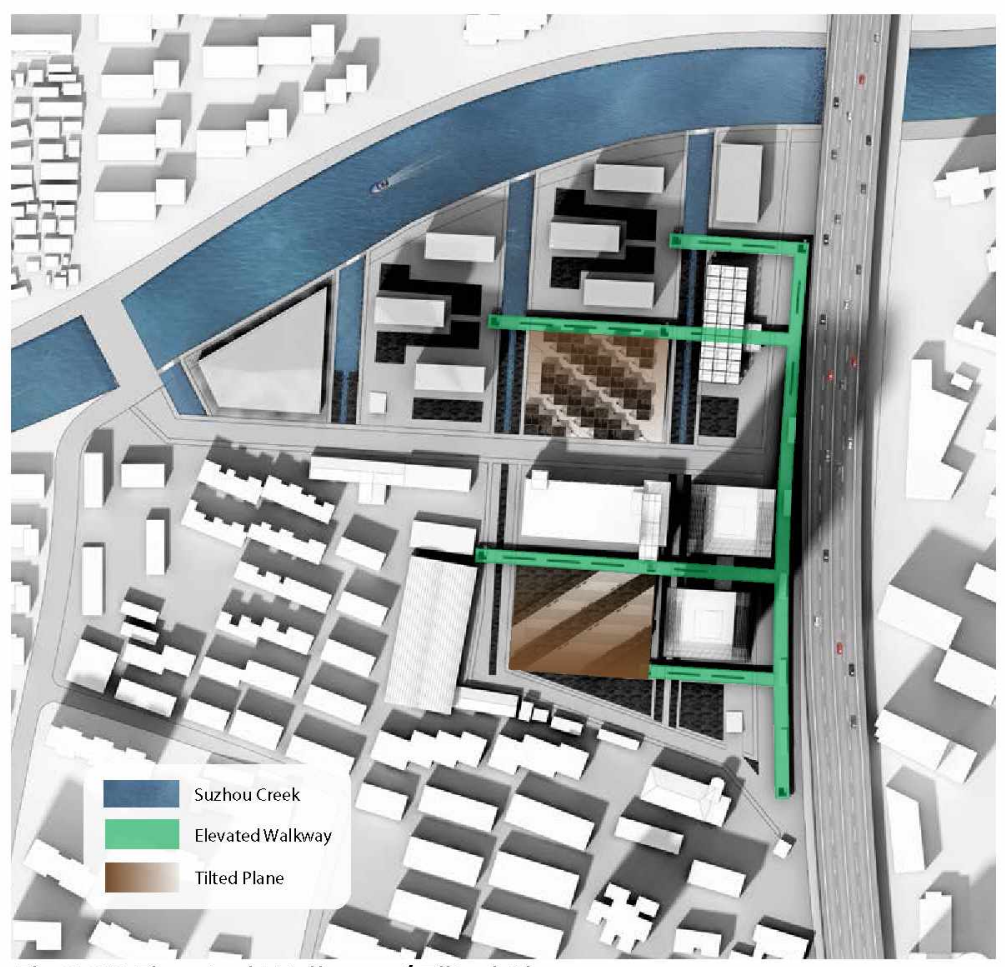

Fig 3.38 Elevated Walkway / Tilted Planes 


\section{Site Circulation}

Vehicular circulation, is accommodated down the middle of the site, dividing the site into two. There are three entrances at the three corners of the site to facilitate people coming from different directions. A shortcut is created in front of the underground parking, creating a loop road around the office tower precinct.

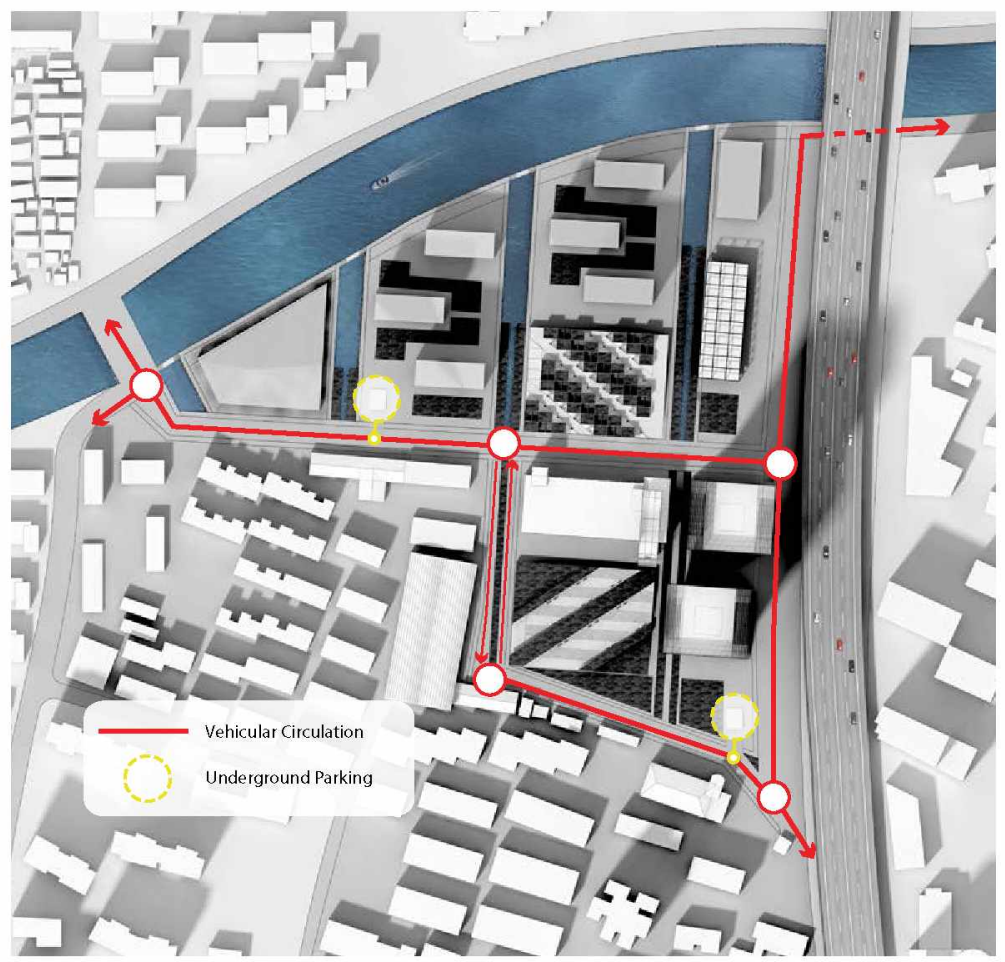

Fig 3.39 Vehicular Circulation 
The Elevated Pedestrian Walkway and Sloped Open Spaces

Having identified it as one of the most distinctive features of the site, the importance of the elevated walkway was reinforced by extending additional "fingers" into the site. However interesting as a feature, the walkway posed challenges with respect to getting up and down from it, how to use the spaces underneath it, and how to connect buildings to it.

In part to address these issues, the open spaces on either side of Building 14 were tilted upward to connect the walkway with the ground plane. Not only did this provide additional (and more monumental) connections between the walkway and grade, but reinforced the southern orientation of these spaces and increased the amount of sun they received. They become, in effect, built landscapes that operate simultaneously as buildings, stairways, gardens and public gathering spaces. 


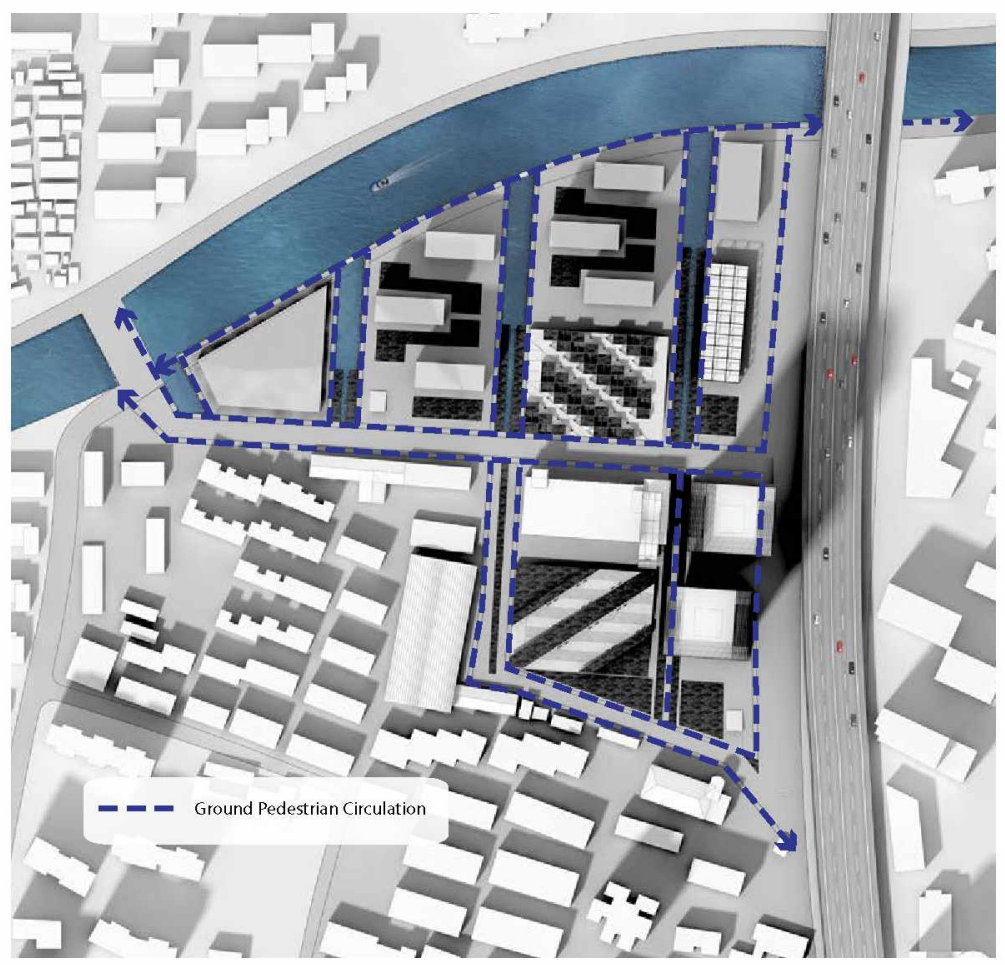

Fig 3.40 Grade-Level Pedestrian Circulation

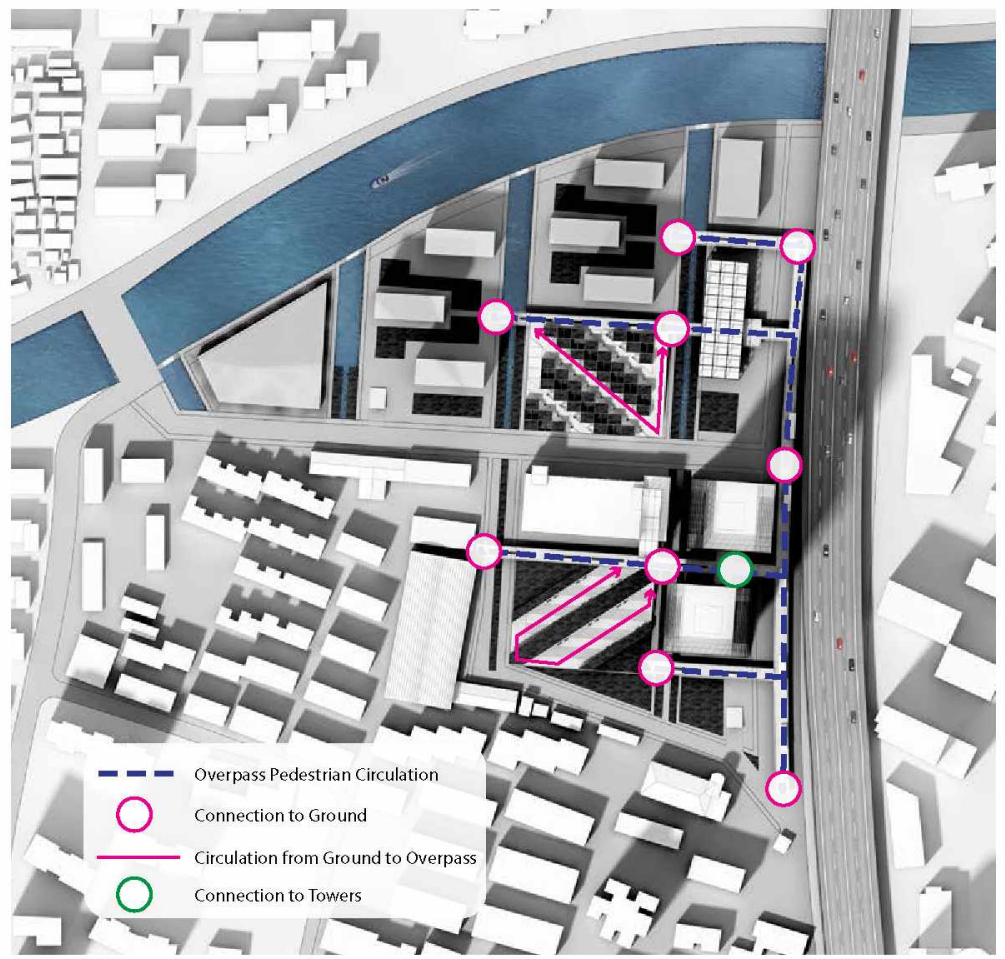

Fig 3.41 Elevated Pedestrian Circulation 


\section{Sloped Housing}

Taking its inspiration from BIG's "Mountain" project ${ }^{2}$ and Shanghai's lilongs, the tilted plane to north of Building 14 would be developed as housing. As a design strategy, this lot was divided into a 6 by 8 meter grid. Diagonal roads have been cut through the grid and sloped up to attach with the elevated walkway.

Alternating cells within the grid were extruded into 2-story live/work units, each 6 meters high with a green roof. Following the SOHO model, the ground floors of each unit can be used either as a workspace or as living space. Discrete entrances allow the upper and lower floors to be accessed separately should the ground floor be used as an office. In this scenario, the front bedroom upstairs can be opened into a living space. The stairs can be configured to give each unit direct access to parking beneath the plinth.

Both floors are provided with exterior spaces: the front yard for the lower level and the rear court for the upper one. The units will be constructed of a combination of concrete and glass. Being located on a slope, the height difference between units makes it possible for sunlight to penetrate into every single unit. 
A total of 34 units were created on the slope, each with an area of $96 \mathrm{~m} 2$. The sloped housing provides 29 dwelling units per acre (UPA); however, the number could be doubled if the ground floor is rented out as a separate unit. 

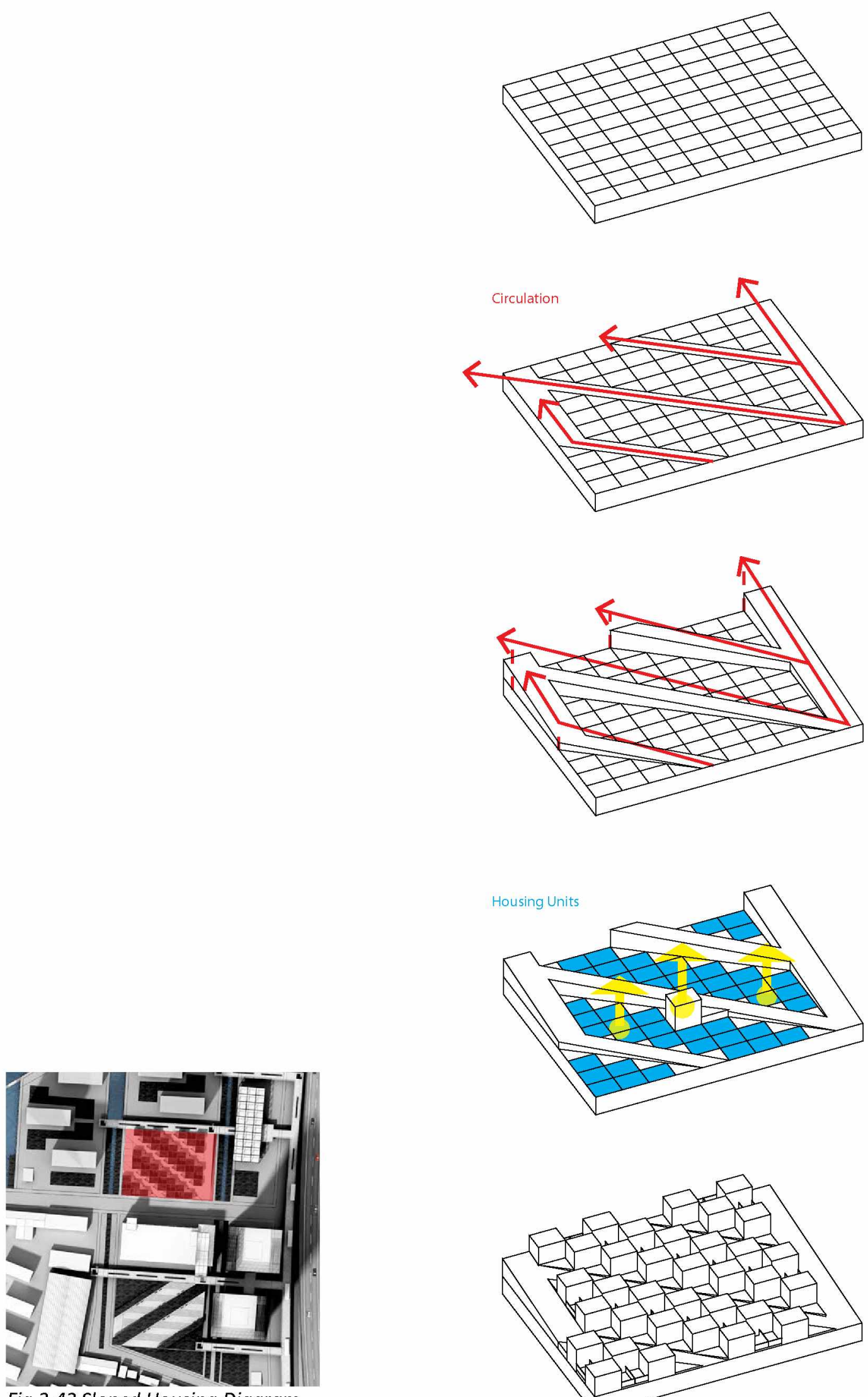


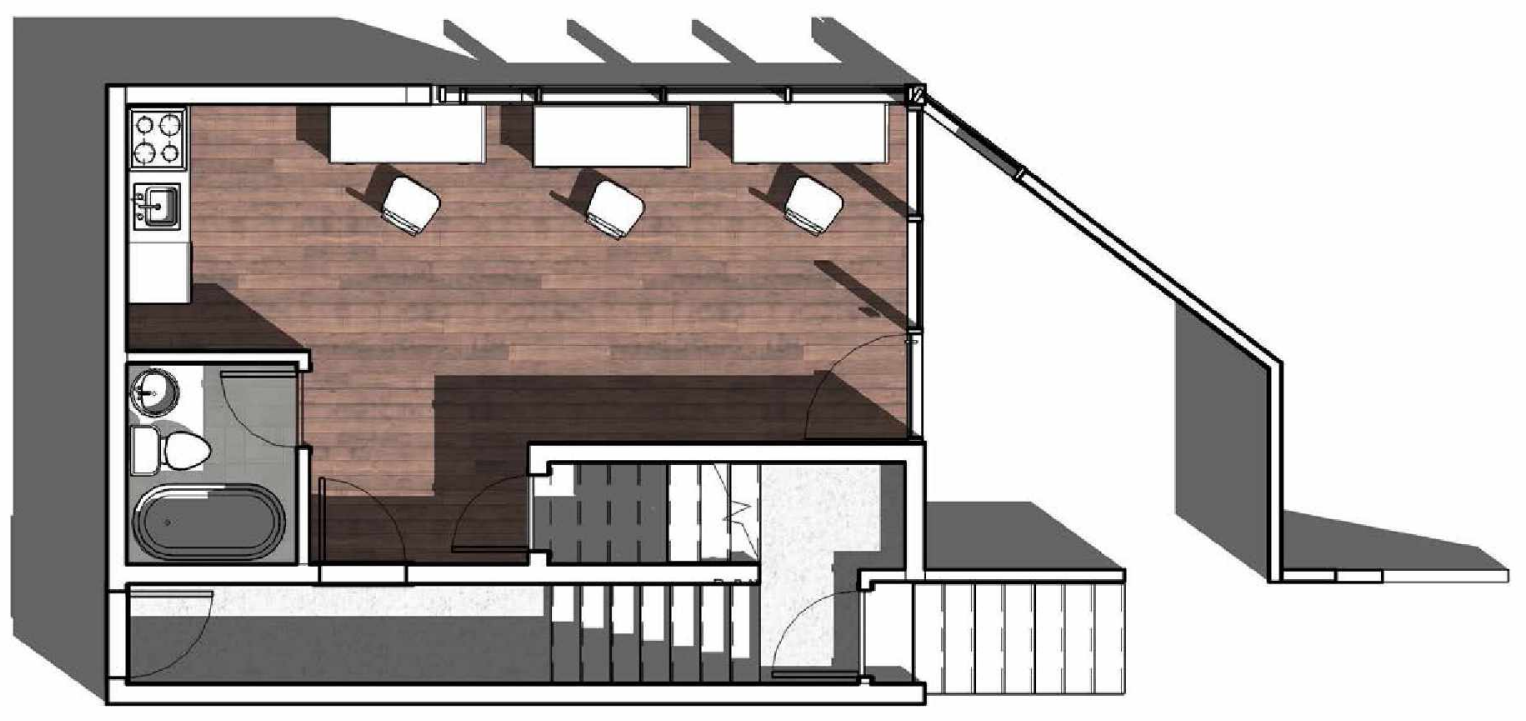

Fig 3.43 Sloped Housing Ground Level Plan

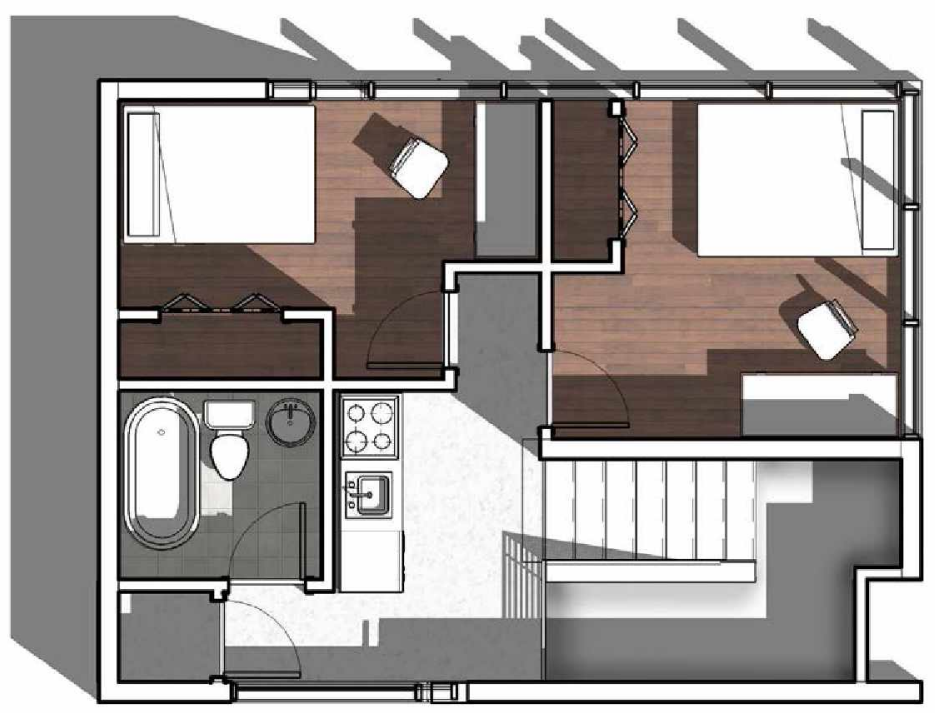

Fig 3.44 Sloped Housing Second Level Plan 


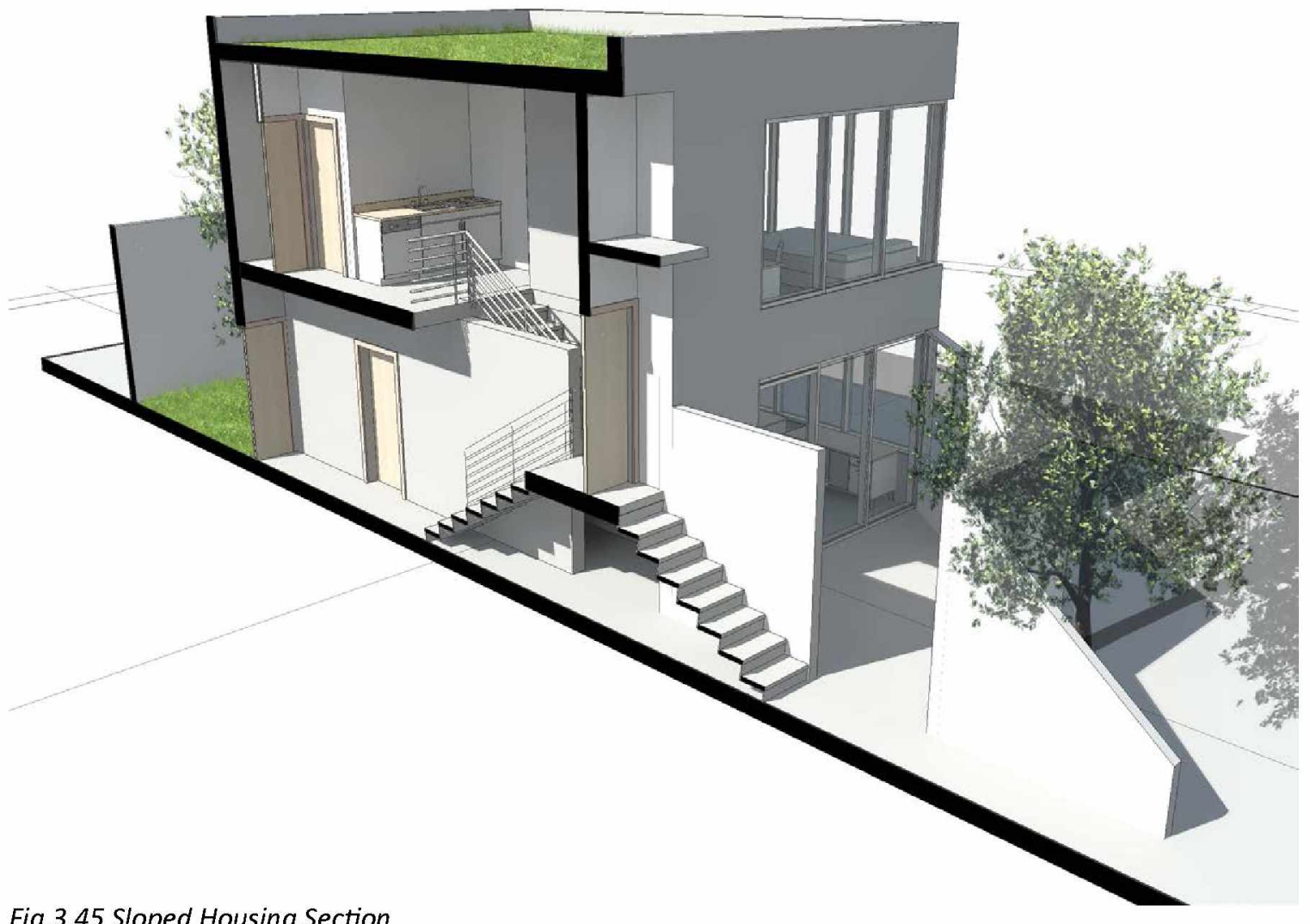

Fig 3.45 Sloped Housing Section 


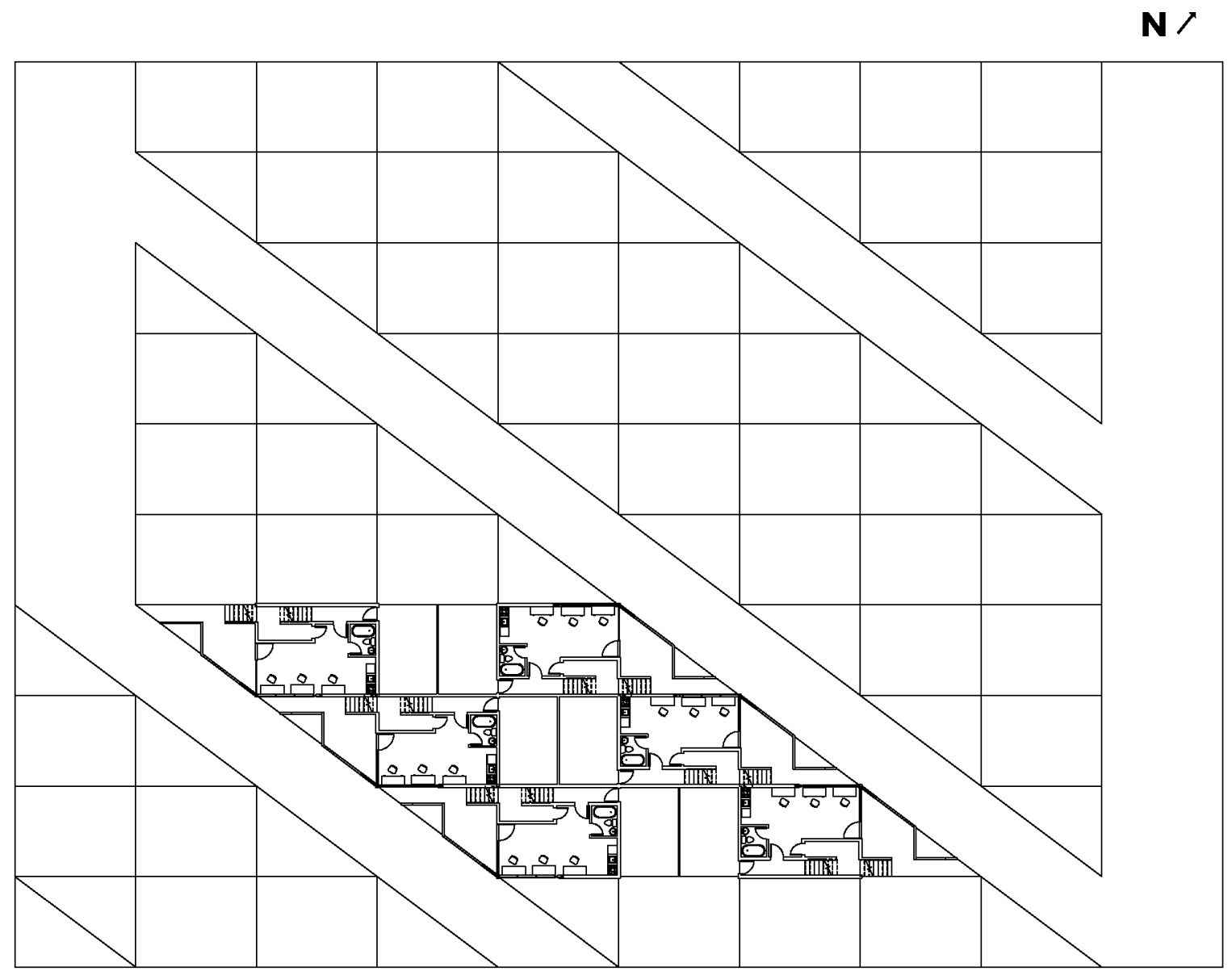

Fig 3.46 Sloped Housing Overall Plan 


\section{Underground Library}

The titled plane on the south side of Building 14 corresponds to the upper floor of the underground library, designed to occupy the parking structure below. Diagonal stairs leading up the plane move between planted areas, the sides of which allow light into the library below. The same grid system has been laid out to create a logical form but in reverse. Diagonal lines cut though the gird and become the roof structure of the library, which is proposed as green space with circulation nearby. The circulation consists of a staircase with a giant landing, which also becomes the celebrated space for people to gather. Two entrances for the library have been provided: one is located in front of the building 14 , under the elevated walkway, and the other is located at the corner of the turn in the road. Upon entering, people will need to take the stairs down to access the main library. 

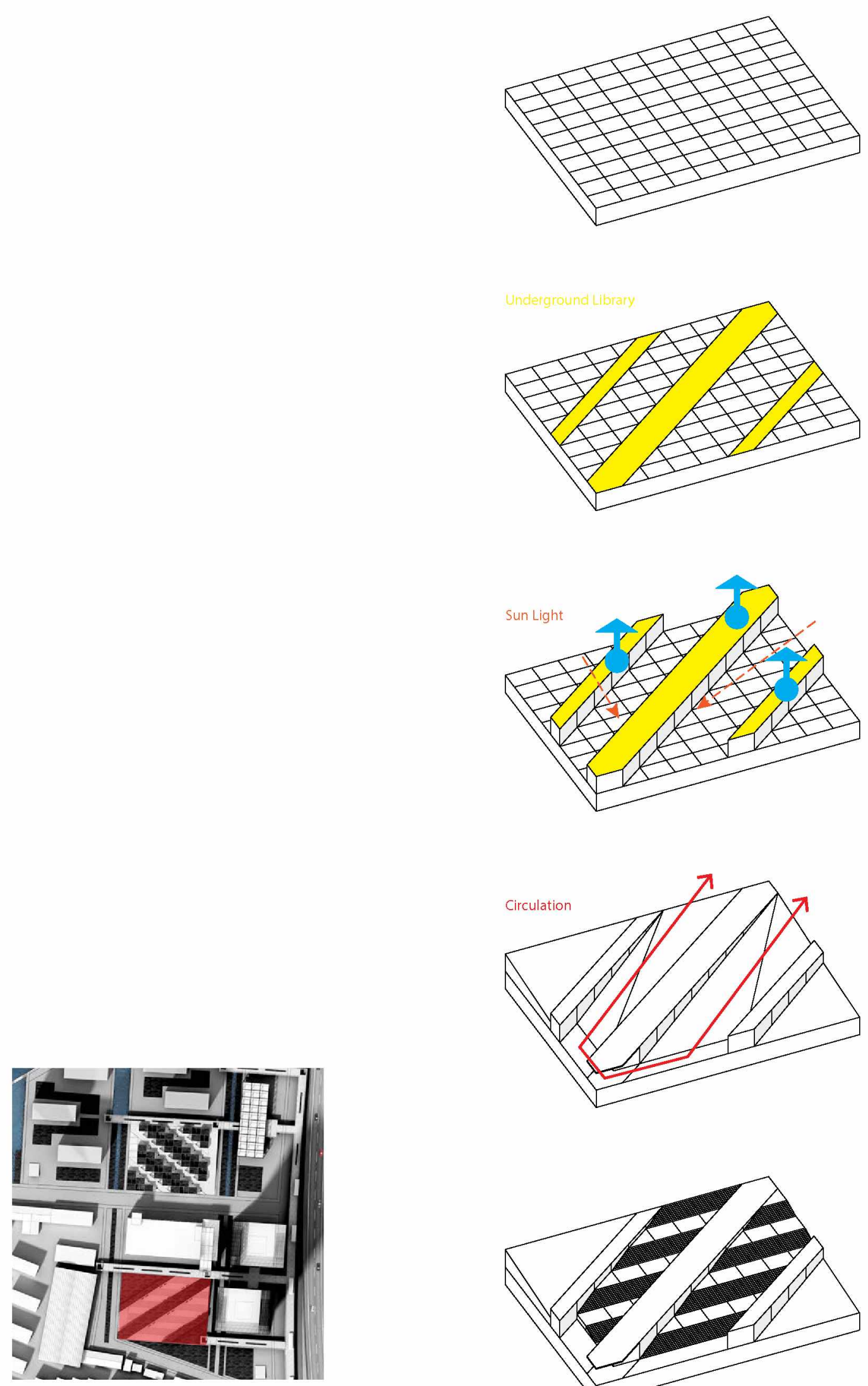

Fig 3.47 Tilted Plane Atop Proposed Library

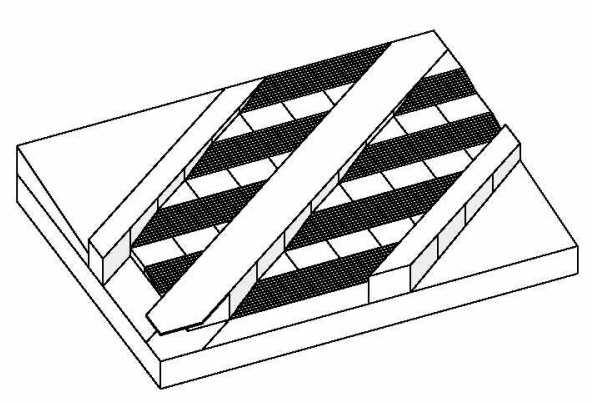




\section{Residential Towers}

The condo slabs at the northern edge of the site vary in height. The slabs closest to the water are 10 storeys, the middle 15 , and those in the final row are 20 storeys tall. The graduation in height reflects a 45-degree sky plane setback requirement along the banks of the Suzhou River. Organized into east/west rows, all condo units face south. Shanghai laws require that

all apartments receive sunlight on the shortest day of the year; this orientation is believed to maximize solar orientation. The buildings are staggered to provide views of the river and to prevent them from casting shadows on each other. Open spaces around the buildings is reserved for residents' daily activities.

\section{The Office Precinct}

The office precinct is comprised of two office towers and Building 14. The twin towers are 160 metres high with 40 floors. The floor plan is roughly square. The core, as the main structure of the tower, also serves as vertical transportation with elevators. From floors one through ten, the floor plan shifts from the central axis a meter - for a total of 10 meters. This shift allows the two towers - which are quite constrained in their position at the base - not to look directly into each 
other. Double-height lobbies both towers connected to the elevated walkway so that people enter the towers from grade of from the walkway. Mechanical floors are placed on $11^{\text {th }}, 26^{\text {th }}$, and the top floor.

Building 14 has a typical floor area of $2,918 \mathrm{~m}^{2}$ with 3 floors, giving a total GFA of $8,754 \mathrm{~m}^{2}$. This factory building is ideal for office usage; tall ceilings and floorto-ceiling windows allow for well-lit and well-ventilated interior spaces. While most of the building will remain unaltered, the light well at the eastern end of the building will be covered by a glass box/vestibule, connected to the elevated walkway. This will help to update the look of the building to better integrate with the adjacent towers.

\section{Other Buildings}

Together the new underground library and the remaining factory buildings constitute the institutional precinct. Large, open spaces and tall ceilings make factory warehouses very suitable for studios, galleries, and laboratories for university students.

Retail uses have been located along the western edge of the site, to the north, so that they are easily 
accessible from the main road can be seen from the elevated ring road. As noted, a recreational centre has been located at the north-western corner of the site, with an area of $10,000 \mathrm{~m}^{2}$. It has programs such as a movie theatre, gym, indoor tennis court, basketball court, and a kayak club; it provides various activities for the community and it is open to the public.

\section{Conclusion}

While far from revolutionary, the proposed redevelopment of this industrial parcel other mixeduse developments in Shanghai. Uses are mixed at the block scale rather than at the district scale (as in Xintiandi) or building scale (as in the recent SOHO approach). Like Xintiandi, however, heritage buildings are incorporated into a new development to help preserve the city's vanishing industrial heritage. This is especially important along the Suzhou River, once the industrial artery through Shanghai. Industrial conversions and skyscrapers can exist side-by side to provide a range of working space for tenants in Shanghai.

In Shanghai, the value of land trumps everything else. As such, density is an important consideration 
where economic viability is concerned. This proposal attempts to balance density with conservation to demonstrate that conservation cannot only be economically viable, but can add to the overall quality, character and success of the development. 


\section{Endnotes:}

1 The rating system was devised by myself and a colleague while working in the office of Gensler \& Assoc. during the summer of 2013

2 The building is designed by Danish architectural practice Bjarke Ingels Group. The apartments are scaling the diagonally sloping roof of the parking garage, from street level to 11th floor, creating an artificial, south facing 'mountainside'. Each apartment has a "backyard" on the roof of the in front, lower-level apartment. 


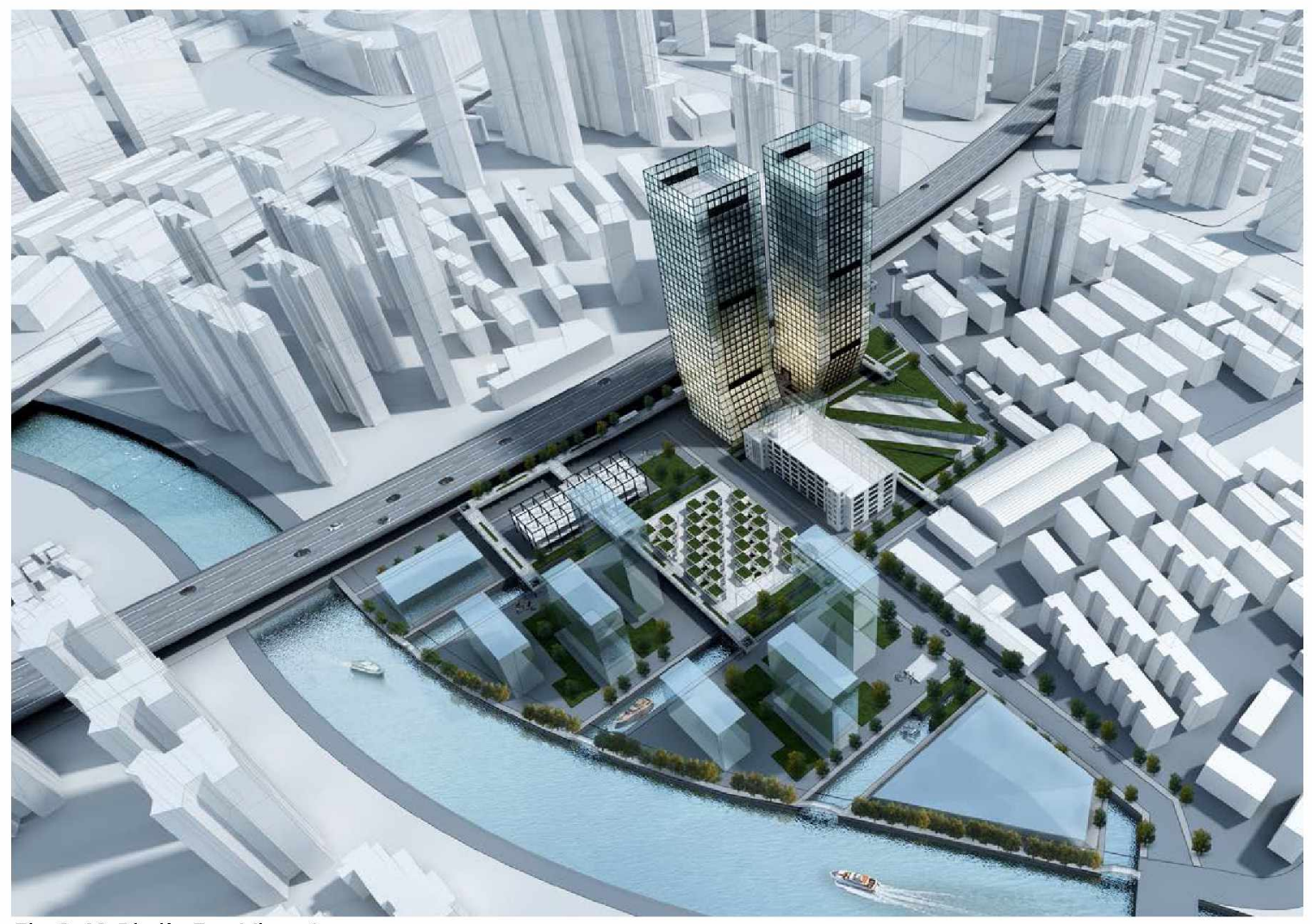

Fig 3.48 Bird's-Eye View 1 


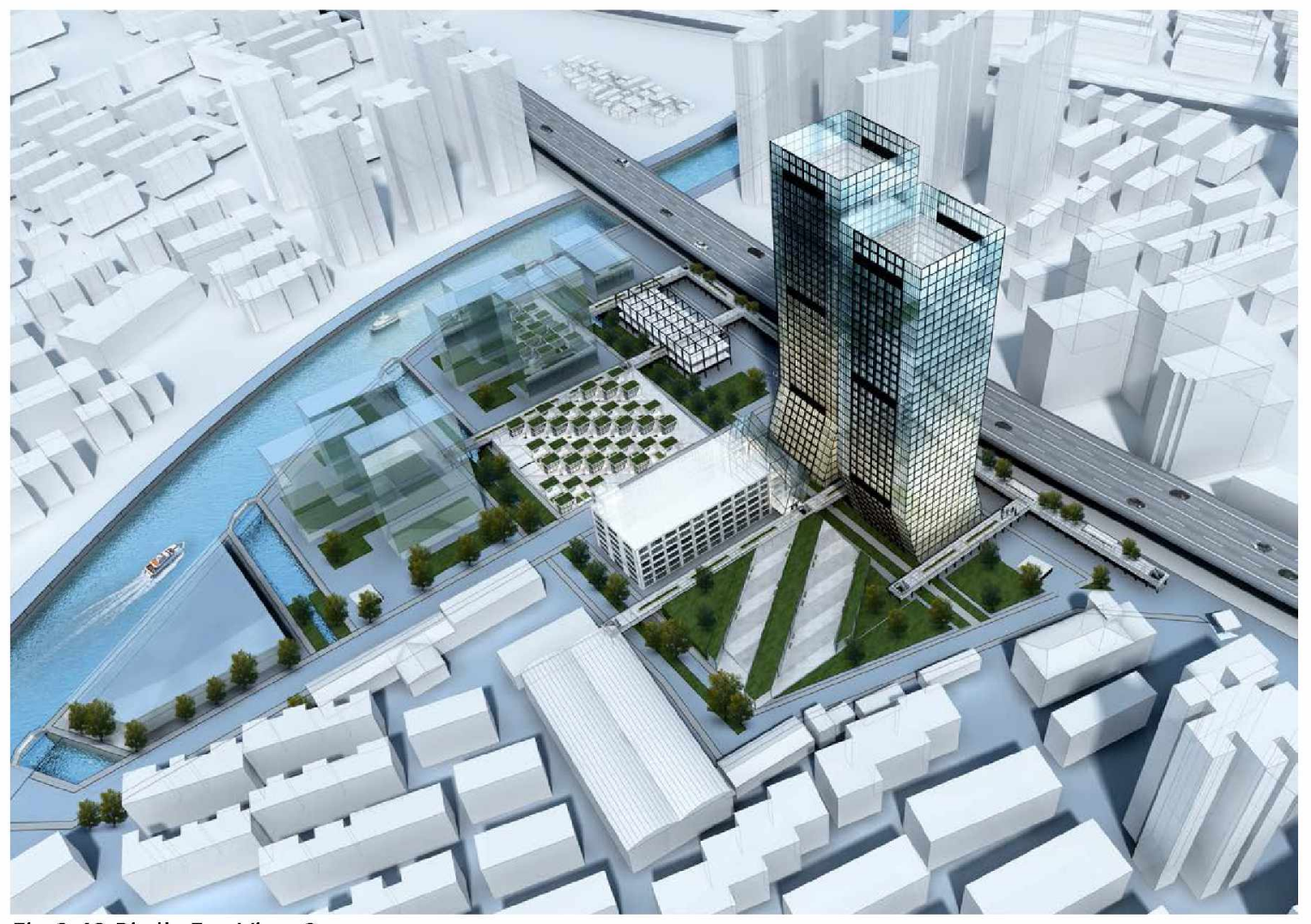

Fig 3.49 Bird's-Eye View 2 


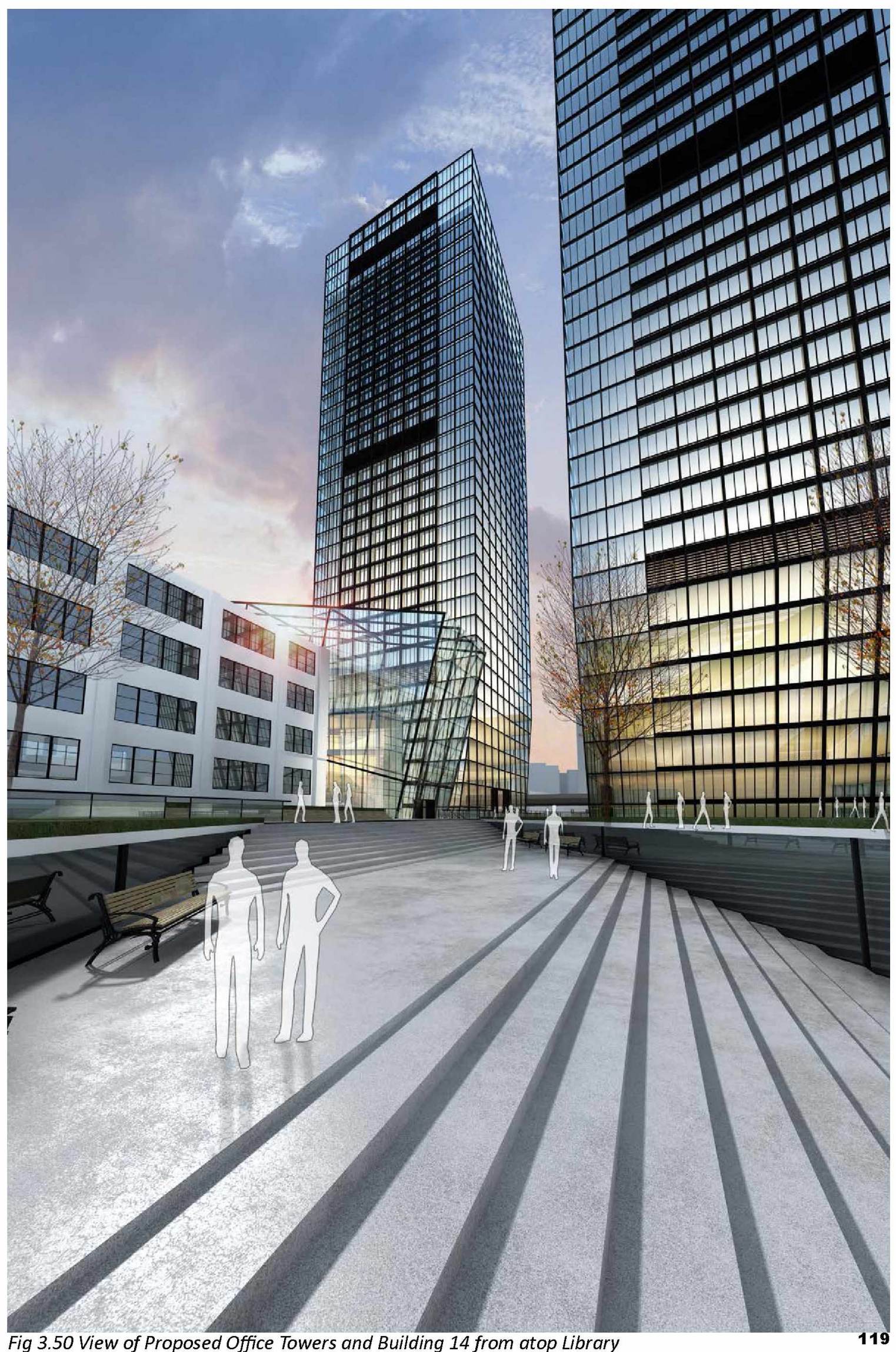






Fig 3.51 View of Live/Work Units and Elevated Walk-way, Looking South from One of the Residential Towers 


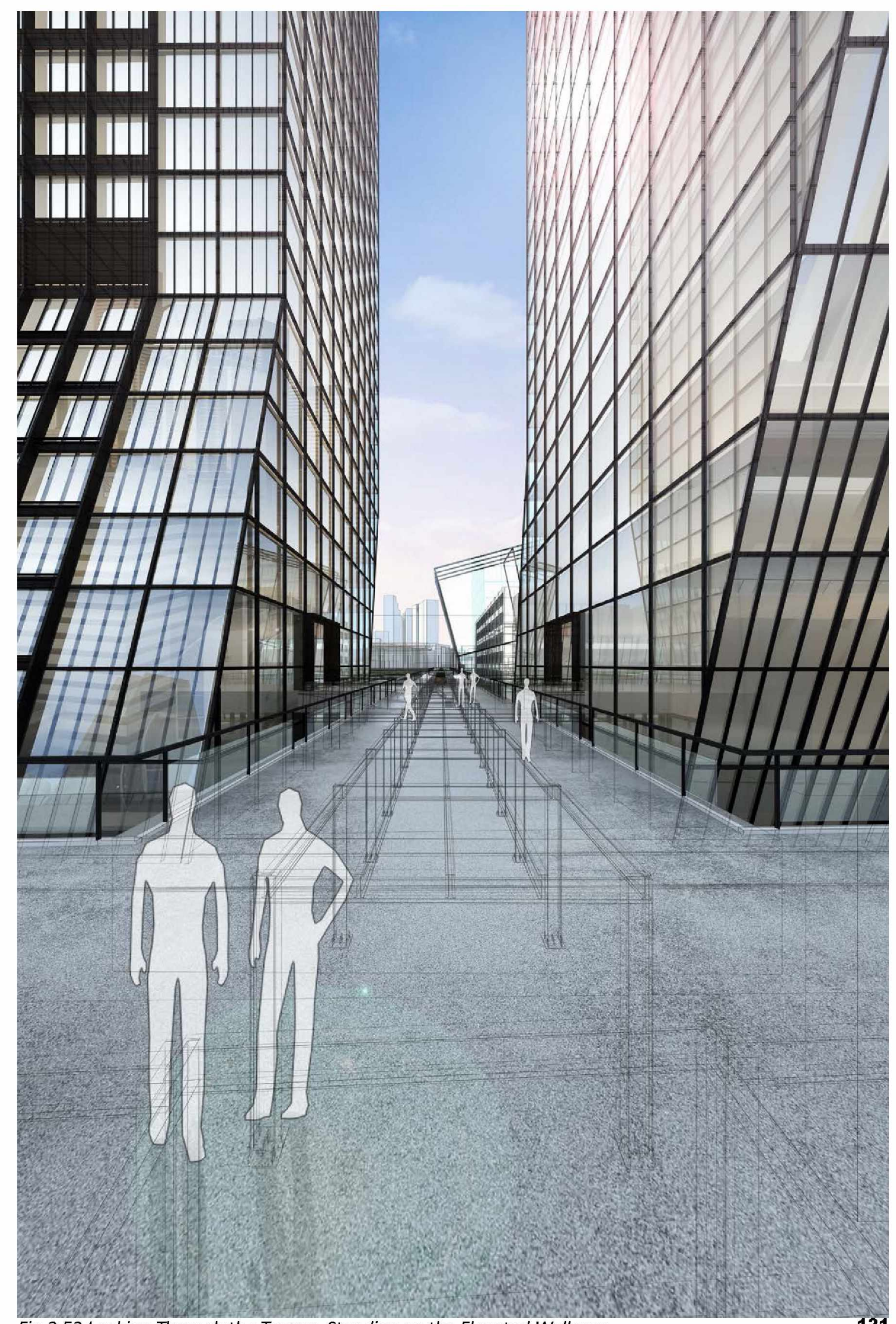




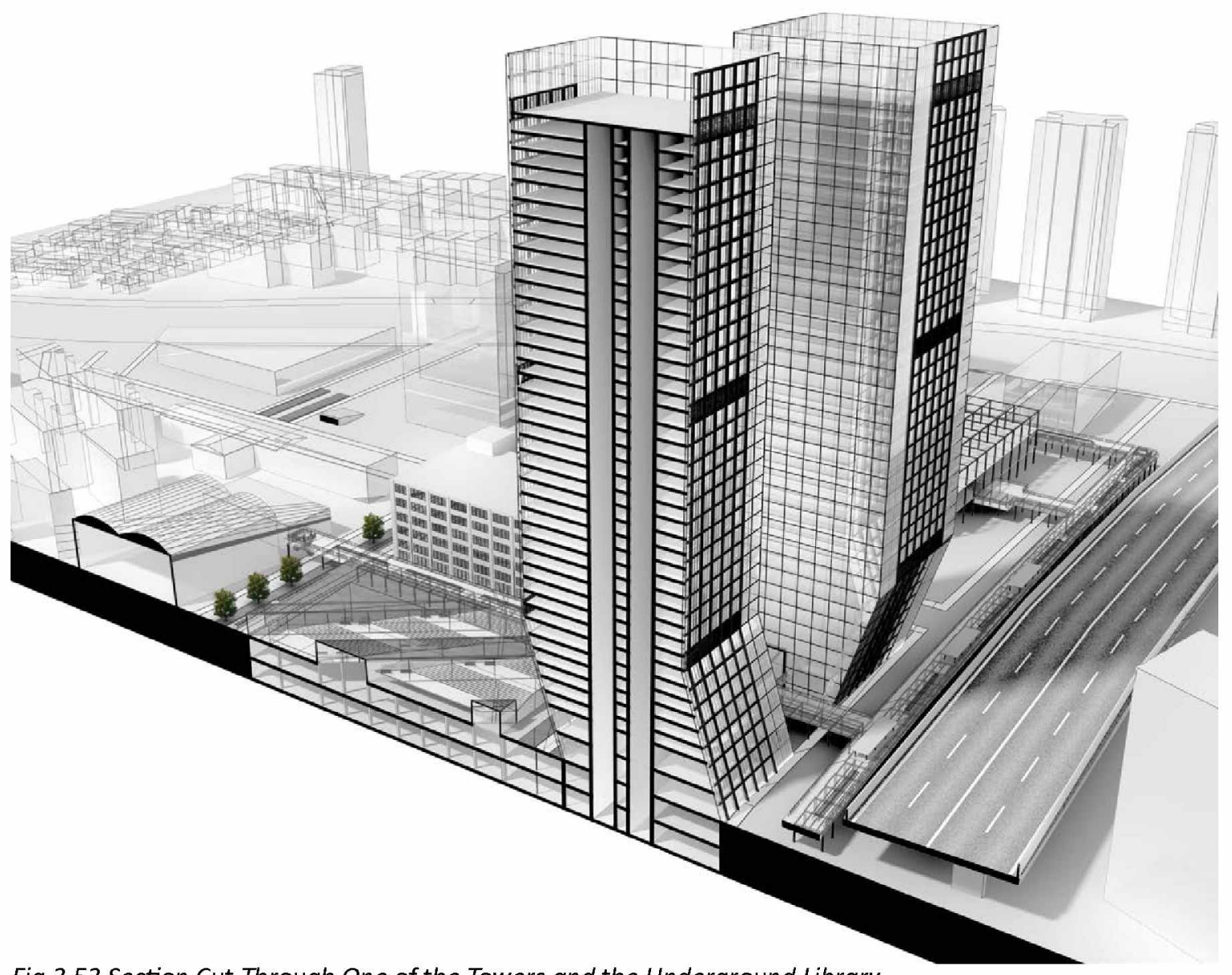

Fig 3.53 Section Cut Through One of the Towers and the Underground Library 
CONCLUSION 
This thesis has examined approaches to redevelopment in Reform-Era Shanghai. Chapter 1 placed recent transformations of the city into a larger historical context while Chapter 2 examined a number of projects and approaches to redevelopment. Of particular interest were the ways in which new office space has been introduced into the city, the mixing of uses, and the integration of new with existing buildings.

The Design portion of the thesis, described in Chapter 3 , explores the same issues though the redesign of a 20-acre industrial site along Shanghai's Suzhou Creek. The proposal should not be interpreted as definitive or by any means inevitable. More than the outcome of research it should be understood as a form of research - a discipline-specific approach to exploring and understanding the range of issues at play. Targets and design strategies for the site were arrived at through an iterative process. The 'final' result reflects the attempt to balance commercial viability with respect the site's industrial heritage. Other approaches are clearly possible - as are innumerable variations on the strategies l've proposed. At issue are 1) which uses to integrate, 2) how much of each to accommodate, 3 ) where to position different functions with respect to the site, 4) where to locate these 
functions relative to each other, 5) which of the existing buildings to retain and to what end, 6) how to integrate the development into the larger urban context and 7) who pays and how much.

Where an overall site structure is concerned, the 'random' location of the existing factory buildings posed challenges. Key to the design proposition, then, was the search for an order in which both new and existing buildings could be accommodated. While the huge open floor plans of the warehouses made them easily adaptable to other uses, their extremely low densities (footprints in relation to GFA) made them problematic from a land-cost point of view. To address this they were assigned institutional uses, similar (although not identical) to the approach taken with similar buildings in Creative Industry Parks. On the northeast corner of the site, existing industrial buildings were assigned commercial usages, which generate a commercially viable rent per square foot. The introduction of office towers on the site also helped to balance the economic equation, as did high-rise housing.

While the larger goal of the thesis was to propose an approach that might be applicable to industrial sites 
elsewhere in the city, the site chosen was in many ways unique. The design, of course, needed to take this into account. Of particular interest were the existing elevated walkway and the spacious underground parking structure, both of which contribute greatly to the design proposal. The fact that the site bordered the Suzhou River was also extremely important. While it might be argued that the proposal was too site specific to be useful as a prototype, the process I followed, coupled with the larger goal of integrating uses and existing with new architecture is certainly applicable to other, similar sites. While it's important to set program and density targets for any given redevelopment project, it's also important to use design to explore options and implications prior to casting those targets in stone. Creating a vision for the site is the best way to generate feedback - which is arguably crucial when developing publically owned land. This issue will no doubt become more important with the growth of China's middle class.

Six months into the design of the project I was given access to land-use maps at the Shanghai Urban Planning \& Design Research Institute (SUPDRI) that indicated the site would be set aside as parkland. While this challenged the assumptions with which 
l'd been working, land-use designations are seldom set in stone. The fate of individual sites is largely determined by the district planning authority (in this case the Changning District), which reserves the right to broker whatever development it deems to be most appropriate or expedient. Indeed, in January of this year construction began on a new building on the site. Discussions with the contractors indicate that it will be a four-story hotel with galleries and entertainment facilities. Unfortunately the Changning planning authority was unwilling to discuss the site's development with me. However inconvenient, this is not unusual in China, where public consultation is rarely a component of urban redevelopment. Normally one must depend on guan $x i$, i.e., work through connections to obtain information.

As of May 2014, construction on the hotel (to the immediate south of Building 14) was about halfway complete and recent excavations suggest that new buildings may also be planned for the east and north sides of Building 14. As such it appears that new buildings may be planned for all of the open portions of the site - which is ironic given its designation as parkland. It's not clear, however, whether the recent excavation relates to proposed buildings or to soil 
remediation. Time will tell.

Interesting, too, is the fact that none of the factory buildings has been torn down to make way for new construction. While Building 1 appears to under renovation, the other factory buildings on site remain untouched.

Given the absence of information in the public domain, one can only speculate on the future of the site extrapolating, as l've done, on the fate of similar sites elsewhere. That being the case, the fact that new, mixed-use buildings appear to be being integrated with existing factory buildings lends credibility to the approach I took.

\section{Next Steps}

Having arrived at the idea for this thesis while working as an intern at the Shanghai office of Gensler \& Associates, the next step will be to present the proposal to architects in the office. As professionals working within the Shanghai development community, their input and insights will be invaluable. Moreover, they may be able to open whatever doors are necessary to 
present the project to the local planning authority and/ or the developers working on the site. Feedback from those with more information than I was able obtain will be key in critically evaluating the assumptions and decisions I made. As noted above, creating a vision for the site is the best way to generate feedback something that I hope will become more common in the ongoing redevelopment of Shanghai. 
Site Visit Updated on May 2014

Fig 4.1 Hotel on the Left, Under Construction

Fig 4.2 Building 1 Under Modification

Fig 4.3 Standing on the Elevated Walkway and Looking Towards to the Building 14 from North

Fig 4.4 Entrance to the Underground Parking, Now Incorporated with the Hotel

Fig 4.5 The East Part of the Building 14 is Under Excavation

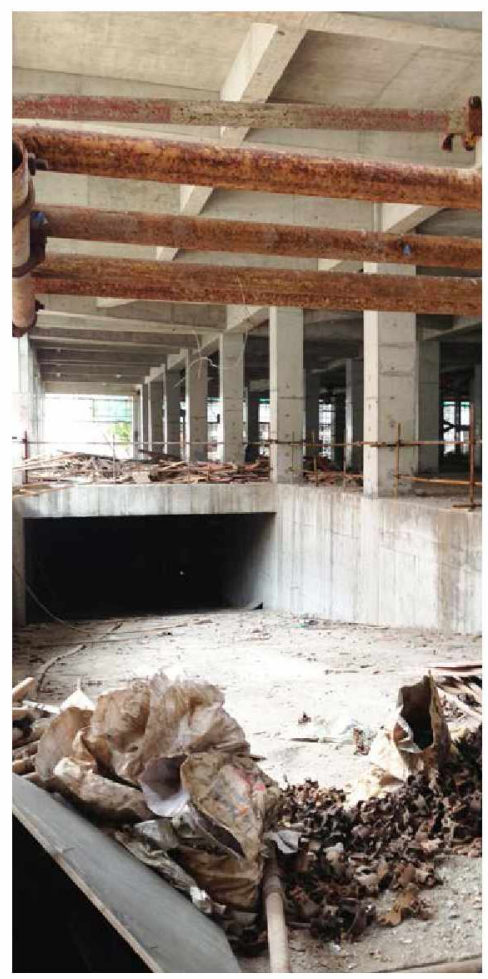

Fig 4.4

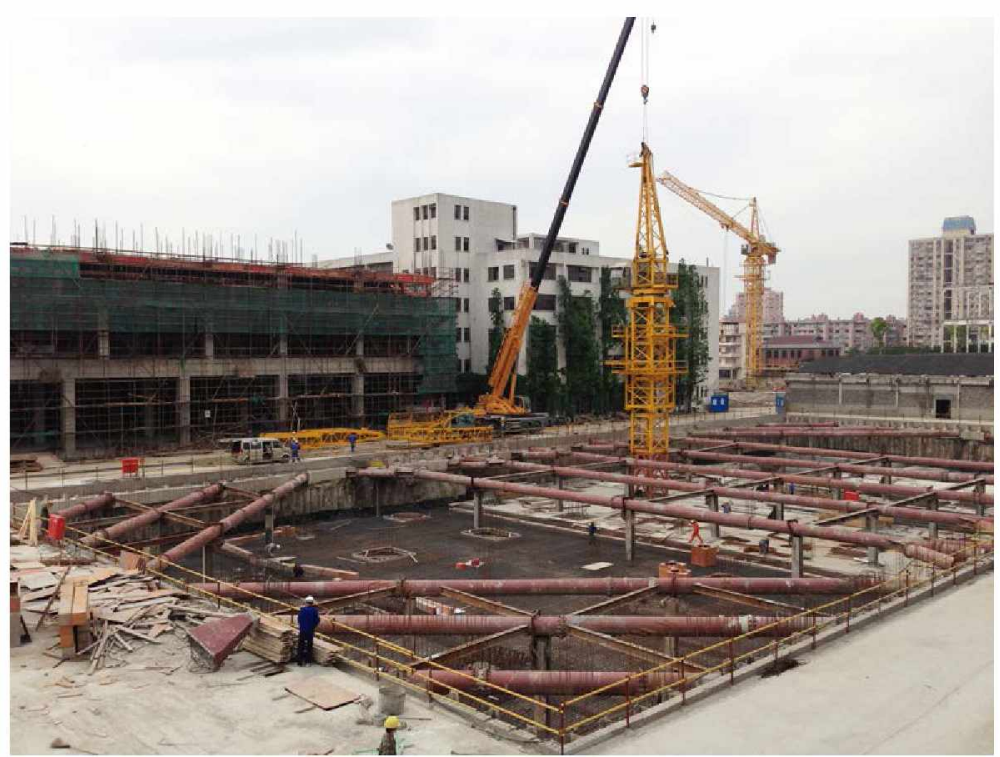

Fig 4.1

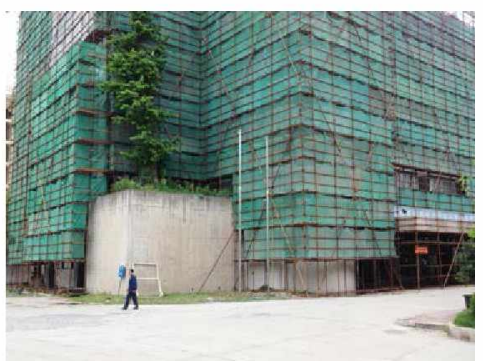

Fig 4.2

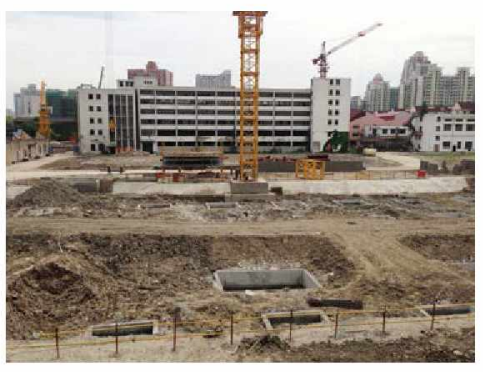

Fig 4.3

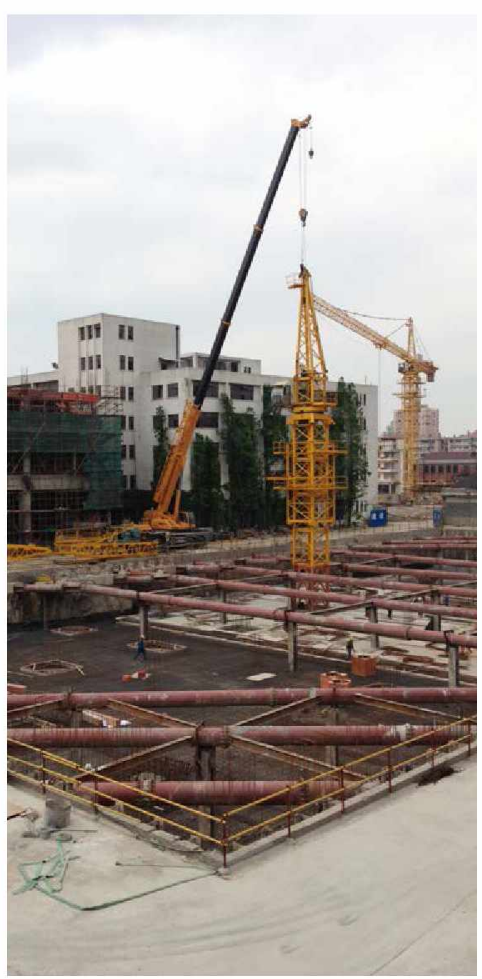

Fig 4.5 
APPENDIX 


\section{LOCATIONS OF THE FOUR DISTRICTS}

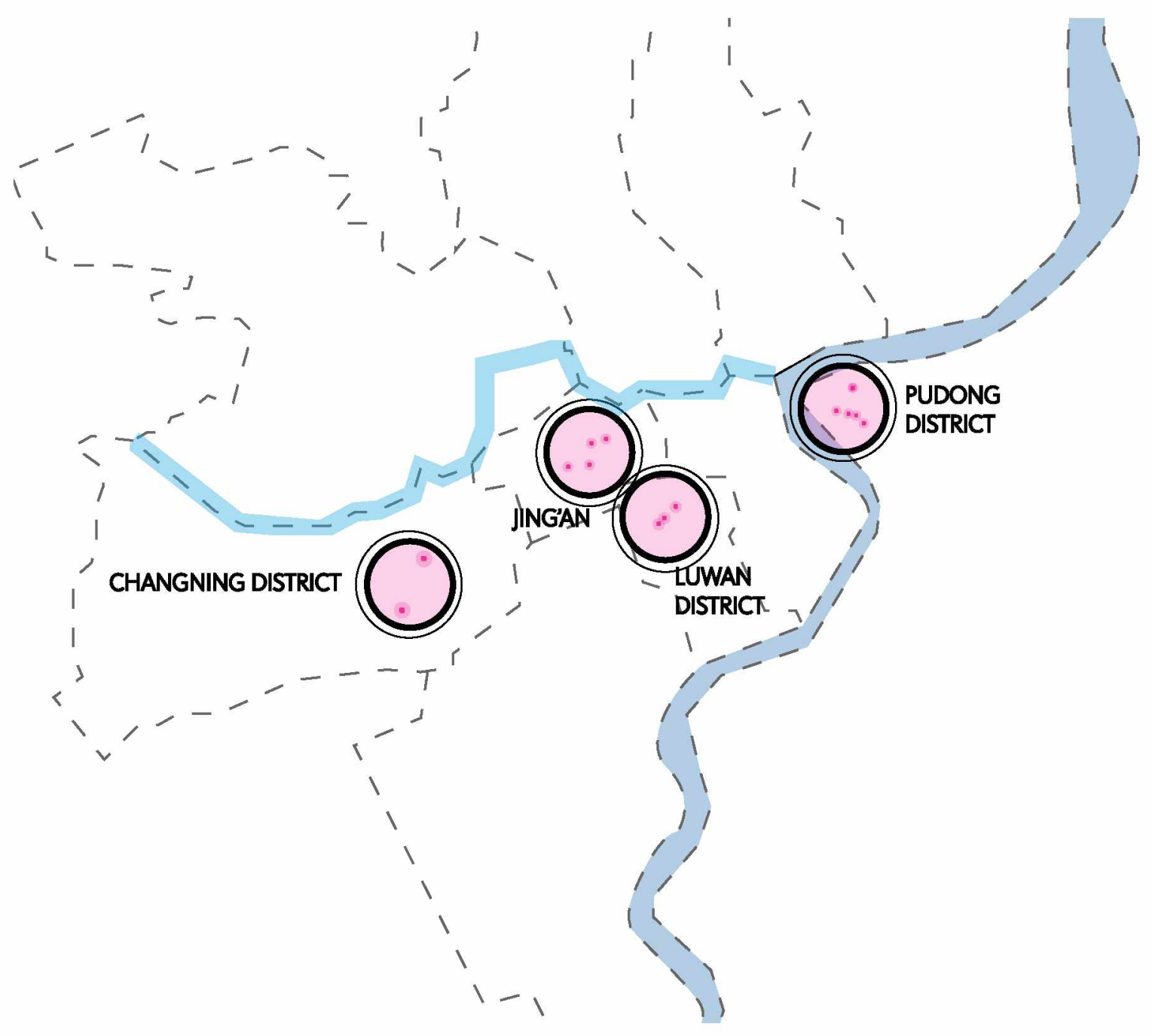




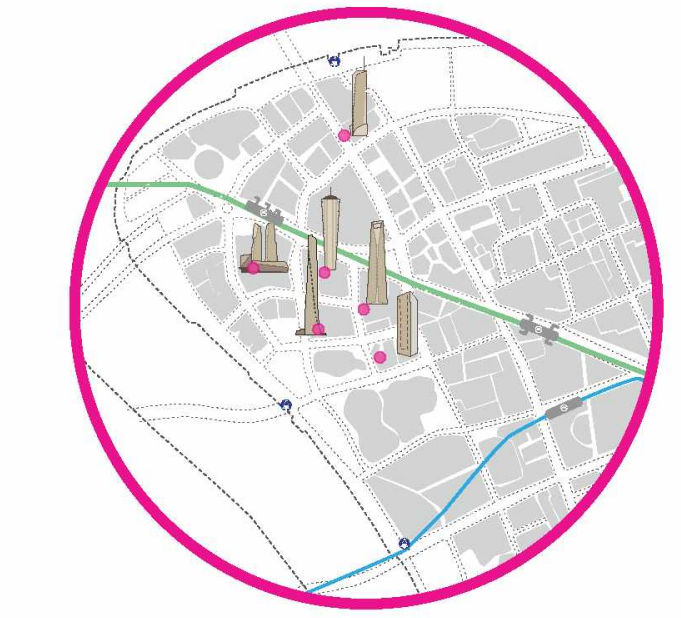

LUJIAZUI
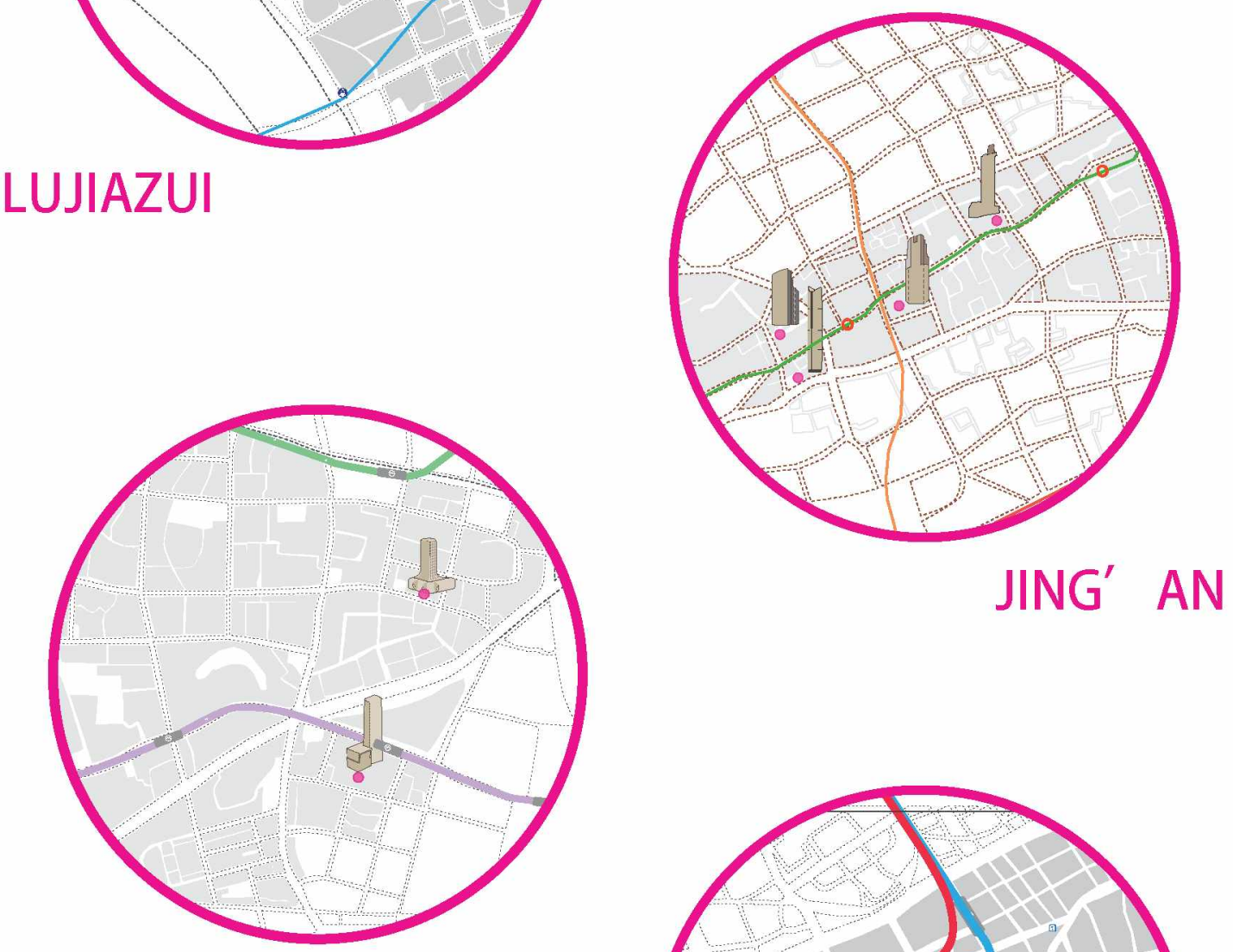

GUIBEI

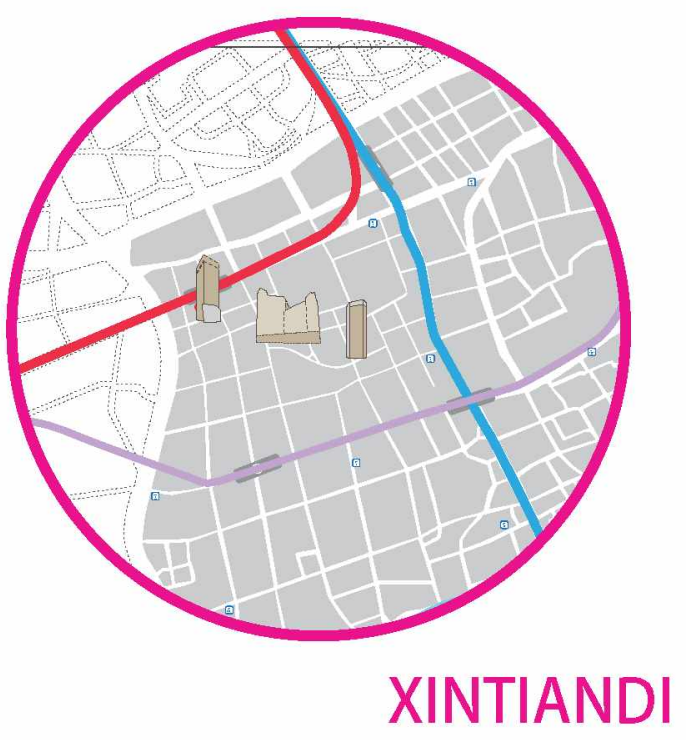




\section{ONE LUJIAZUI LUJIAZUI AREA}
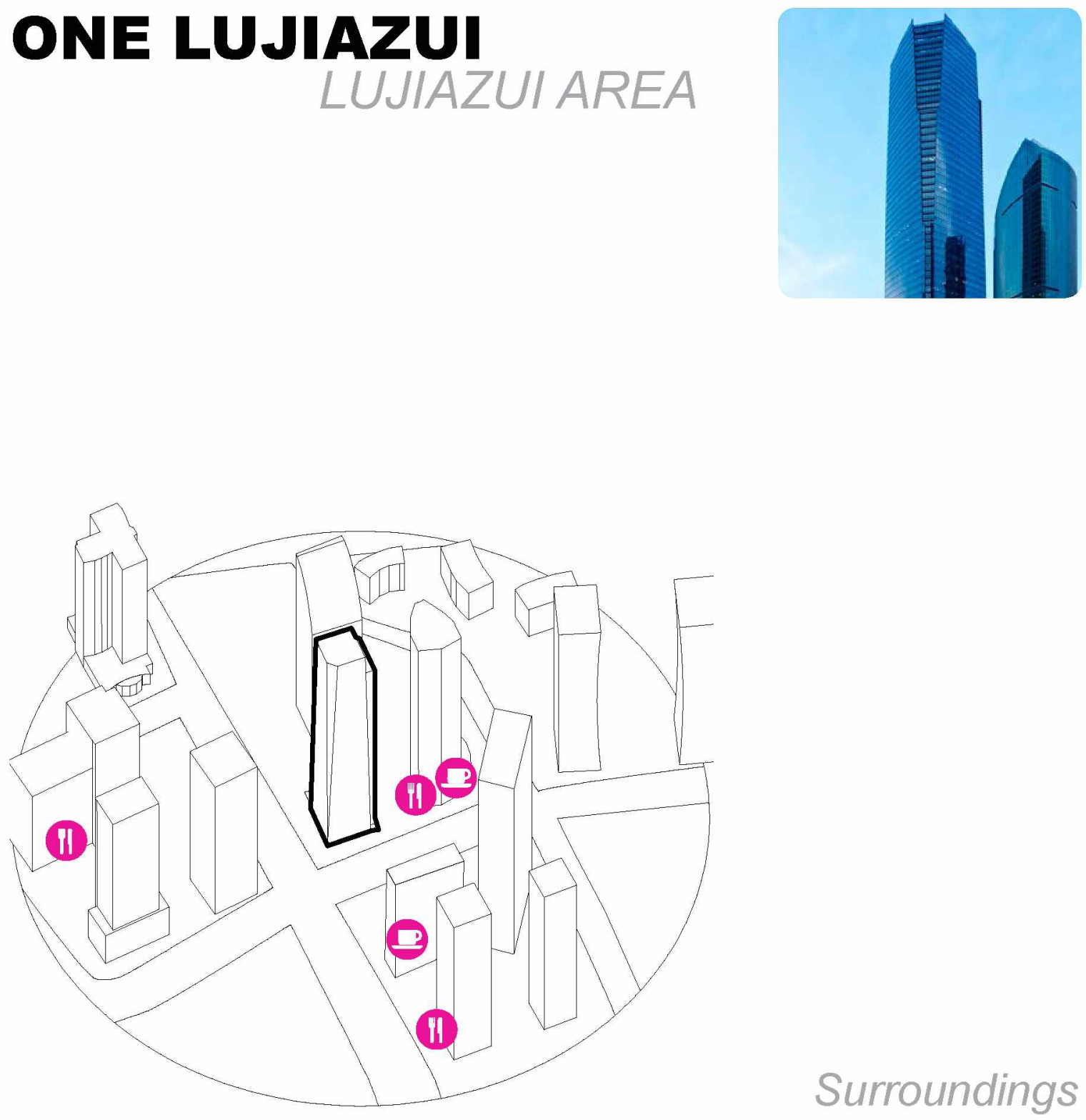

Surroundings

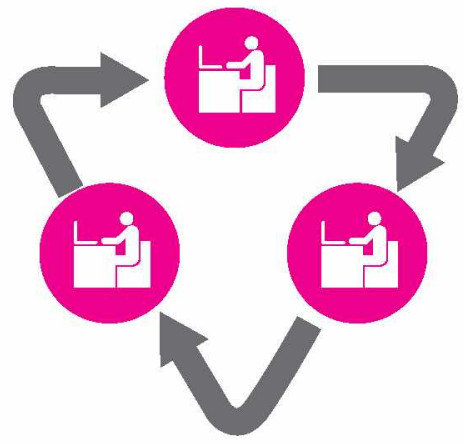
(2) CAFE
(II) DINING
(iii) SHOPPINC
울: LIVING 


\section{ONE LUJIAZUI}

GFA $\frac{\text { TOTAL GFA }}{97 \mathbf{~ s q m}}$

(7) FLOOR PLATE
1900 sqm

(Nv) LIFTS

GFA GFA / SERVED

AI $5383 \mathrm{sqm}$
(1) BUILDING HEIGHTS 269.2m

(1) CLEARANCE
$\mathbf{2 . 8} \mathbf{m}$

琶No. $\frac{\text { TOTAL FLOORS }}{61 F}$ LEED STAN-
SILED
SILVR
(P) $\frac{\text { PARKING LOTS }}{400}$ FIN $\frac{\text { FINISHED YEA }}{\mathbf{2 0 0 8}}$

(\$) RENT
11 RMB
IM2/DAY

MANAGEMENT FEE 33.6RMB IMOMTH

\section{Plan}

Section

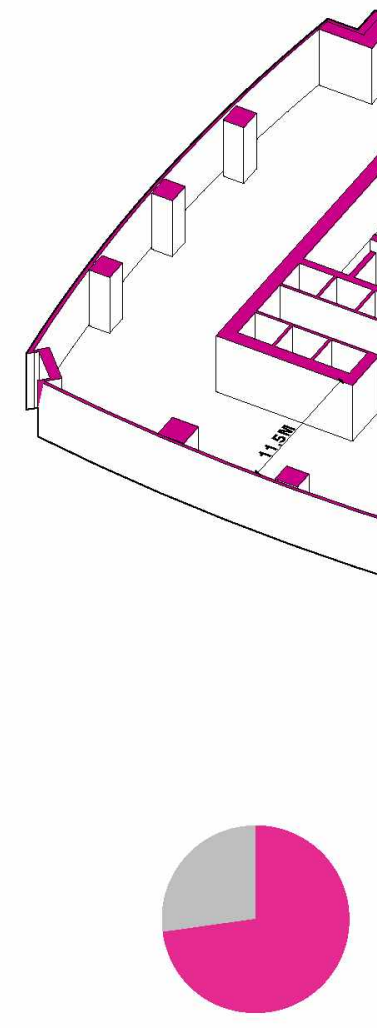

$73 \%$

FLOOR EFFICIENCY

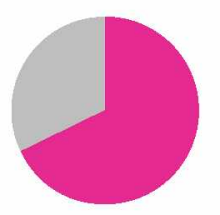

$68 \%$

OCCUPANCY

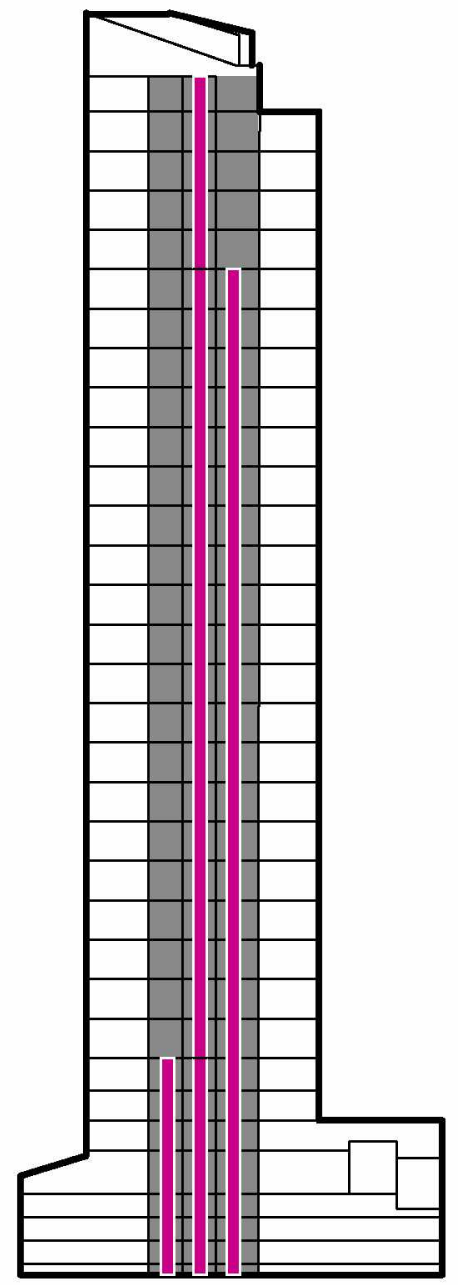




\section{SHANGHAI WFC LUJIAZUI AREA}
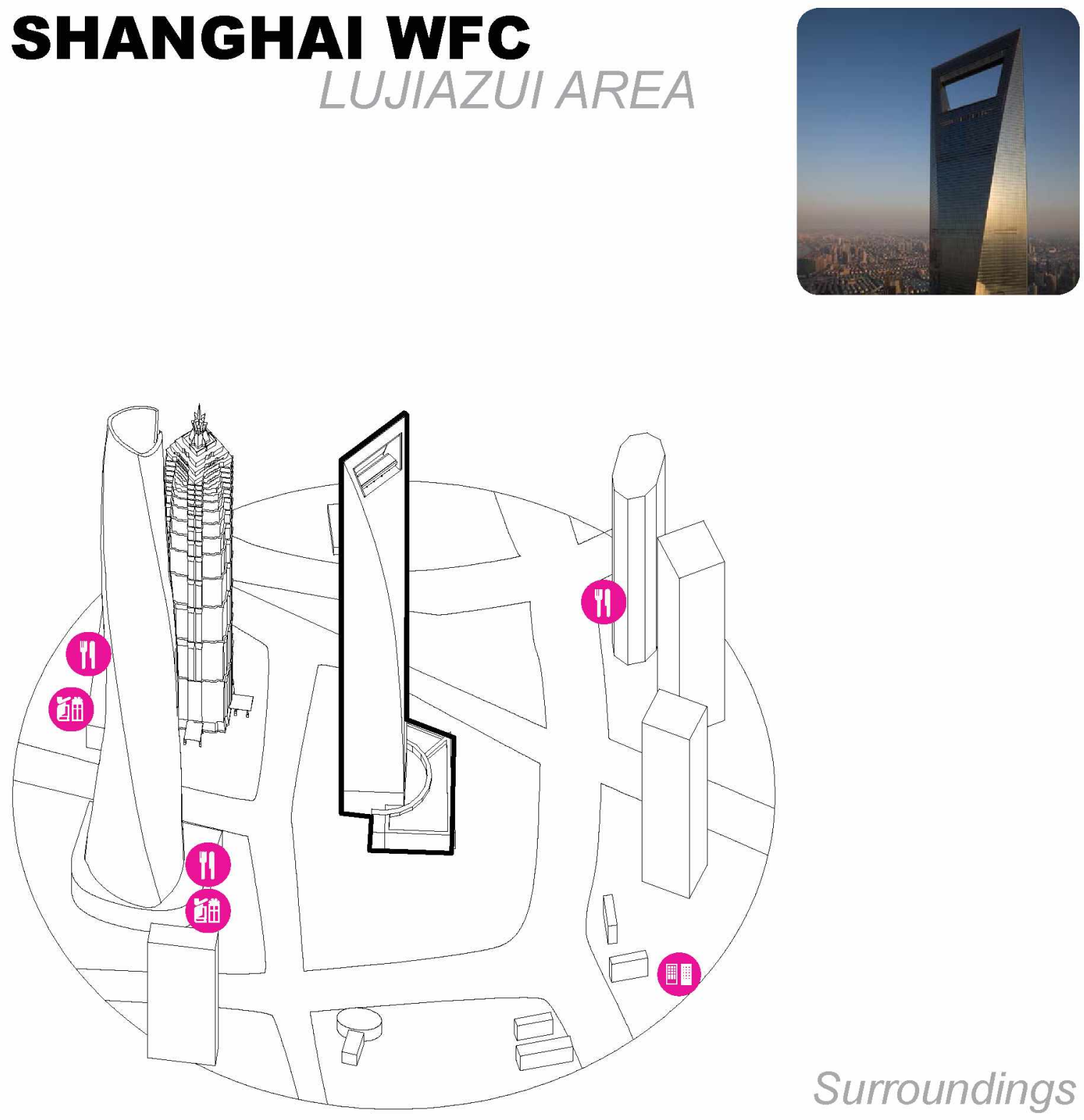

Surroundings

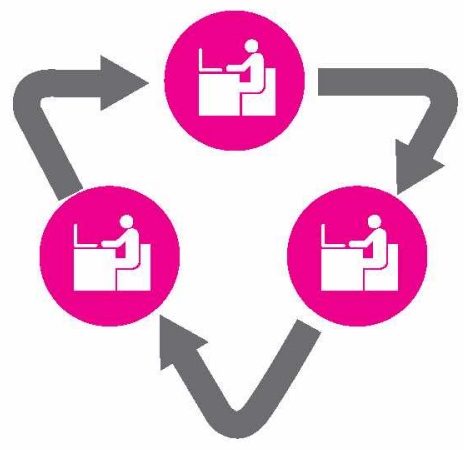
(2) CAFE
(II) DINING
(iiii) SHOPPINC
울: LIVING 


\section{SHANGHAI WFC}
GFA TOTAL GFA
(11) $\frac{\text { BUILDING HEIGHTS }}{492 \mathrm{~m}}$
(P) 1100
(7) FLOOR PLATE
(1) $\frac{\text { CLEARANCE }}{\mathbf{2 . 8} \mathbf{m}}$
FIN $\frac{\text { FINISHED YEA }}{2008}$

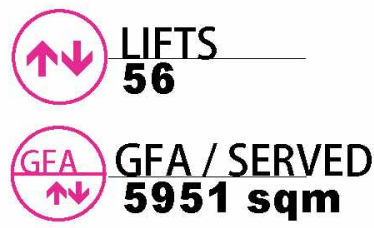
䉪No. TOTAL FLOORS

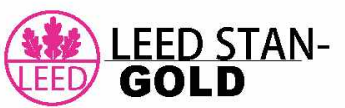
(\$) RENT
14RMB
IM2/DAY
M) MANAGEMENT FEE
58RMB IMOMTH
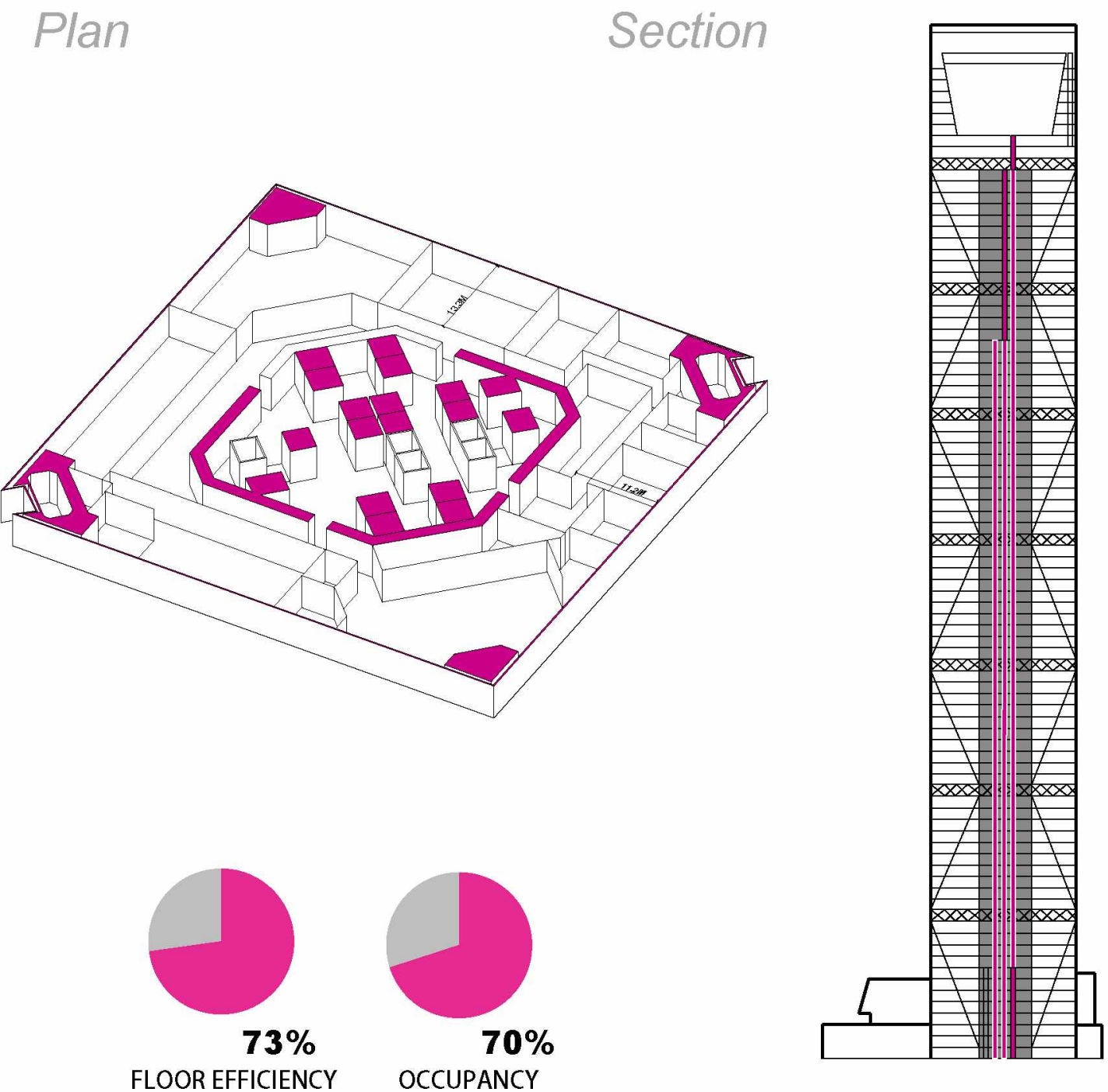


\section{WHEELOCK \\ JINAN AREA}
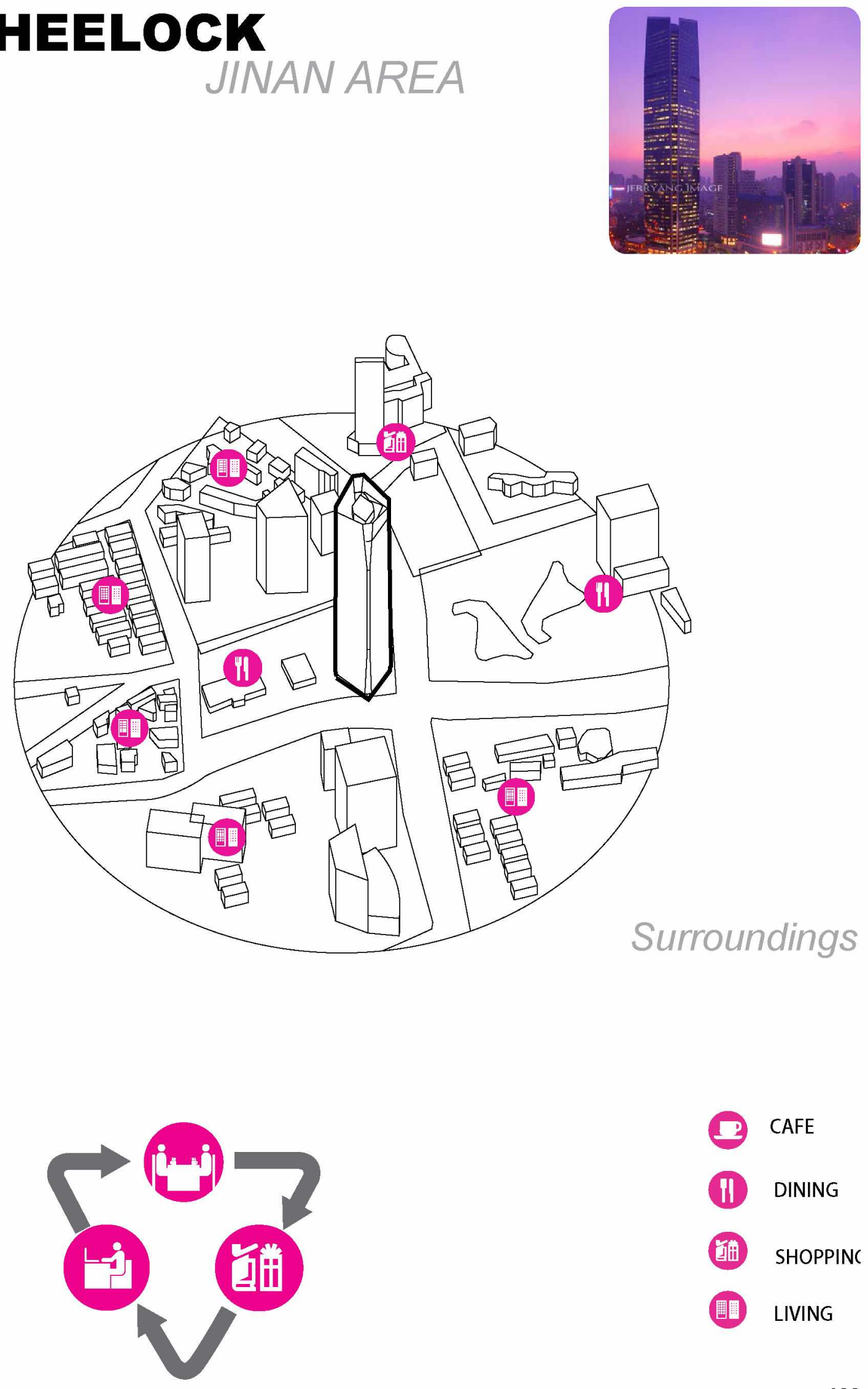

$O^{\text {ant }}$

(1) onnG

(7) shopere

윤 LIVING 


\section{WHEELOCK}

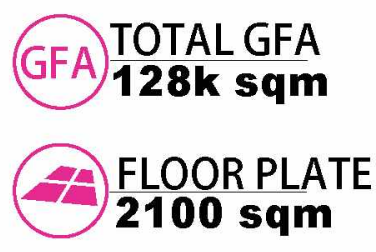

(Av) $\frac{L F T S}{24}$

GFA GFA / SERVED

iv $5337 \mathrm{sqm}$



TOTAL FLOORS
(N1F
No.

(1) LEED STAN-

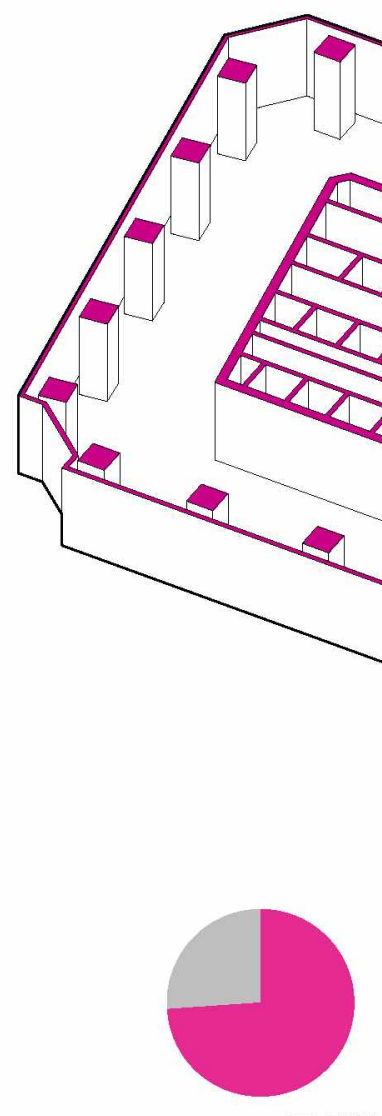

$74 \%$

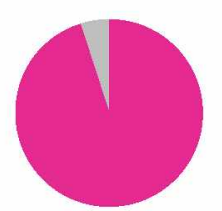

95\%

OCCUPANCY
(P) PARKING LOTS FIN $\frac{\text { FINISHED YEA }}{\mathbf{2 0 1 0}}$



\section{Section}

FLOOR EFFICIENCY



\section{Co.AVENUE 1 \\ XINTIANDI AREA}
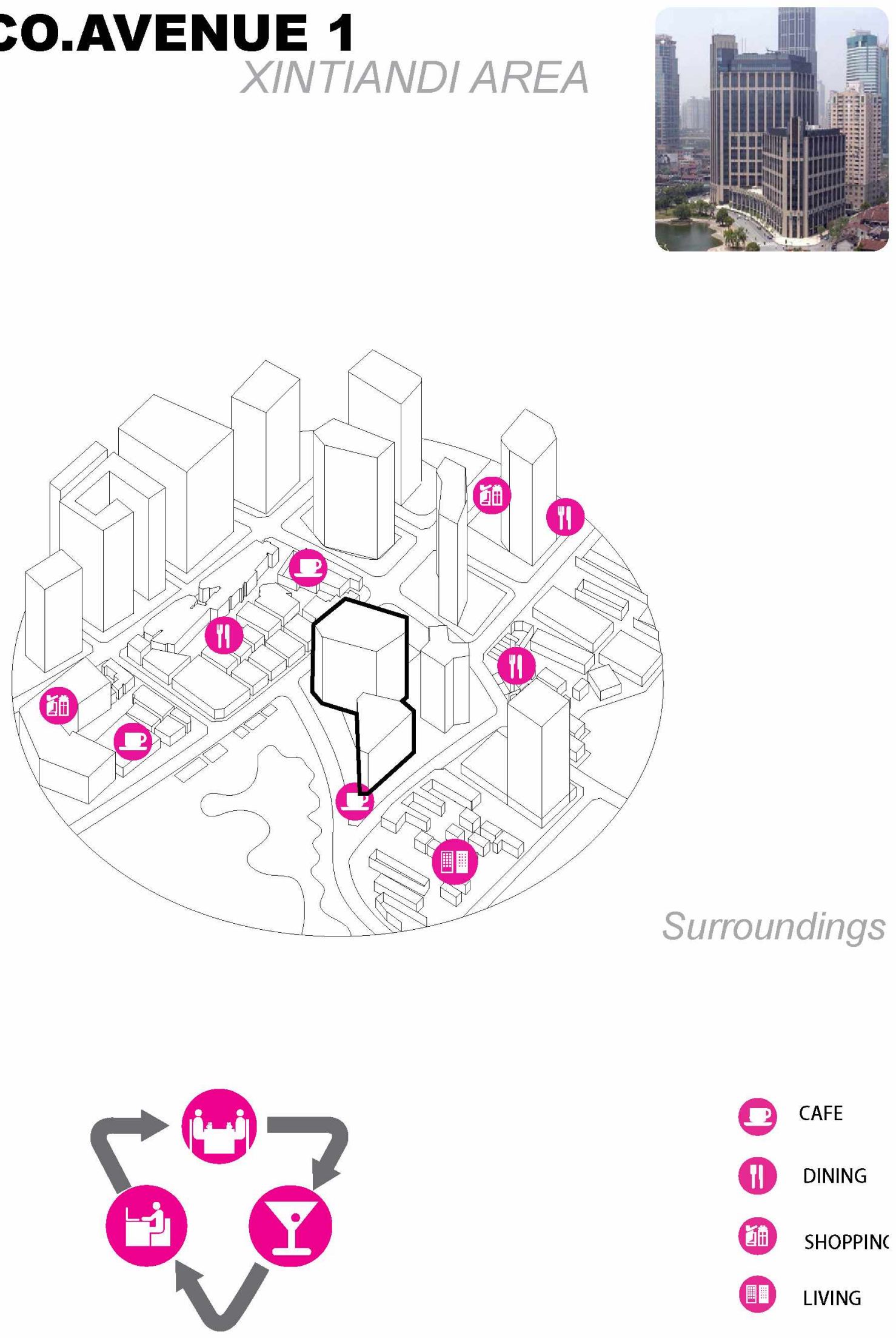

O wre

(1) bume

(i) stromen

울: LIVING 


\section{Co.AVENue 1}

\begin{tabular}{|c|c|c|}
\hline GFA $\frac{\text { TOTAL GFA }}{\mathbf{8 4 k ~ s q m}}$ & (11) $\underset{\mathbf{9 8}}{\text { BUILDING HEIGHTS }}$ & (P) $\frac{\text { PARKING LOTS }}{\mathbf{1 1 2}}$ \\
\hline $\begin{array}{l}\text { FLOOR PLATE } \\
\mathbf{2 9 0 7} \mathbf{~ s q m}\end{array}$ & $\begin{array}{l}\text { CLEARANCE } \\
\mathbf{2 . 8 \mathbf { m }}\end{array}$ & $\begin{array}{l}\text { FINISHED YEA } \\
\mathbf{2 0 0 4}\end{array}$ \\
\hline LIFTS & (No.) $\frac{\text { TOTAL FLOOR }}{29 \mathrm{~F}}$ & $\begin{array}{l}\text { RENT } \\
16 \text { RMB } \\
\text { /M2/DAY }\end{array}$ \\
\hline $\begin{array}{l}\text { A) GFA / SERVED } \\
\mathbf{5 2 6 8 \mathbf { s q m }}\end{array}$ & LEED STAN- & $\begin{array}{l}\text { MANAGEMENT } \\
\text { 32RMB } \\
\text { /MOMTH }\end{array}$ \\
\hline
\end{tabular}

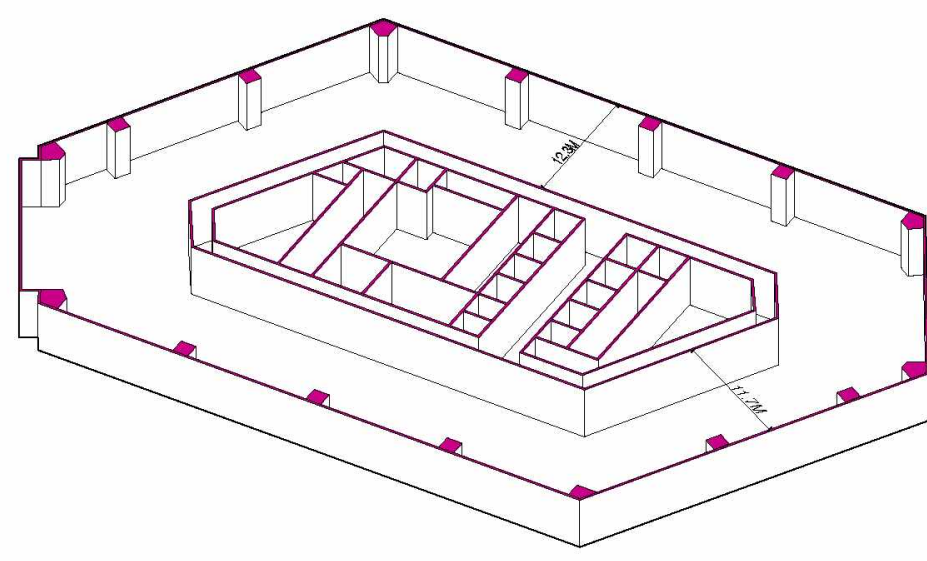

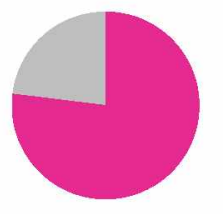

$77 \%$

FLOOR EFFICIENCY



$95 \%$

OCCUPANCY

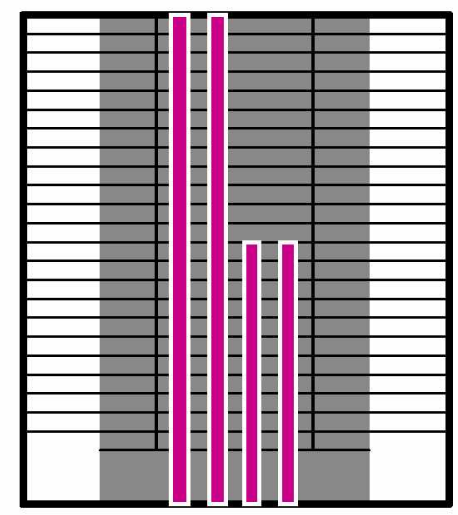




\section{GIFC}

\section{GUBEI AREA}
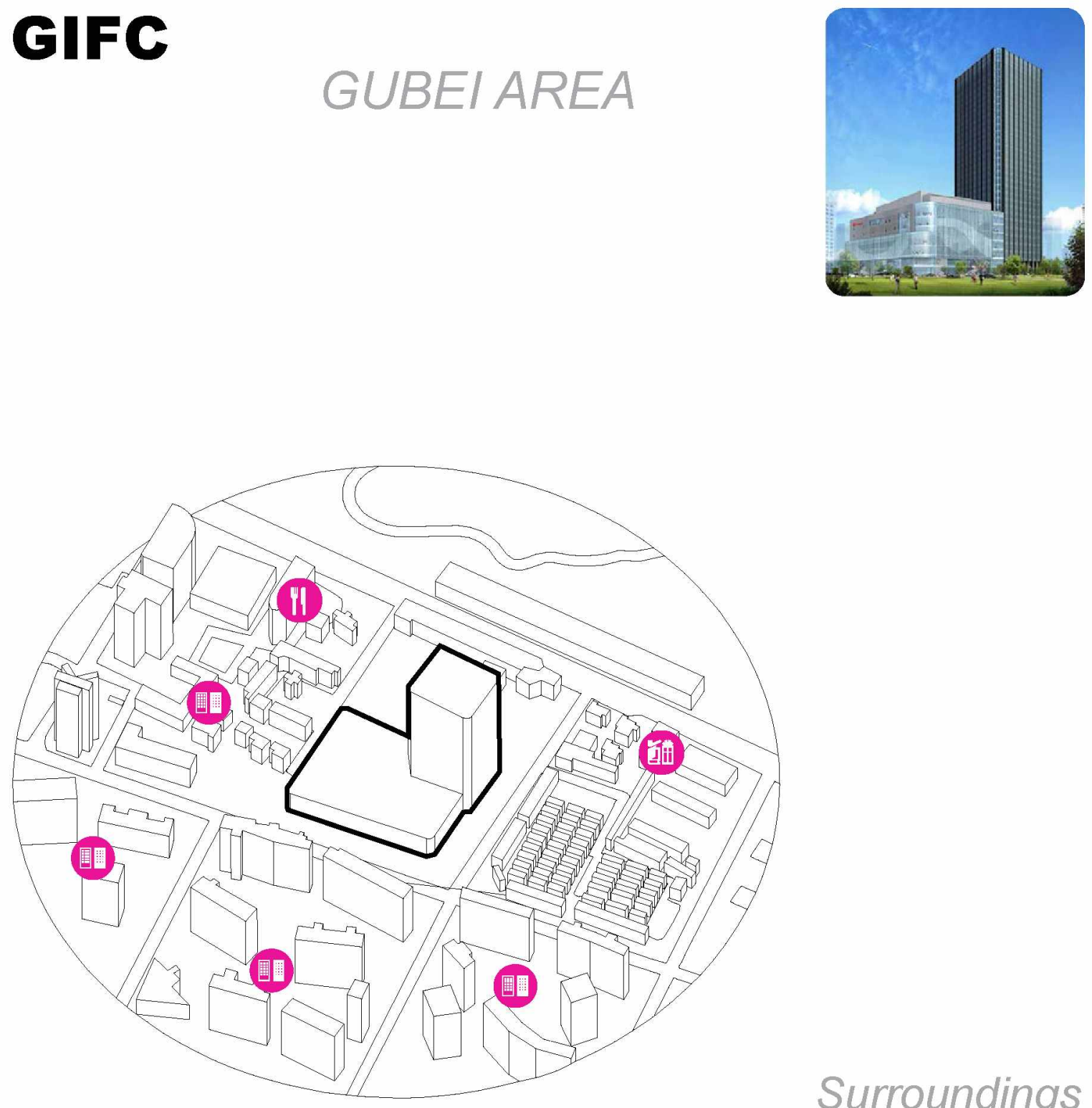

Surroundings

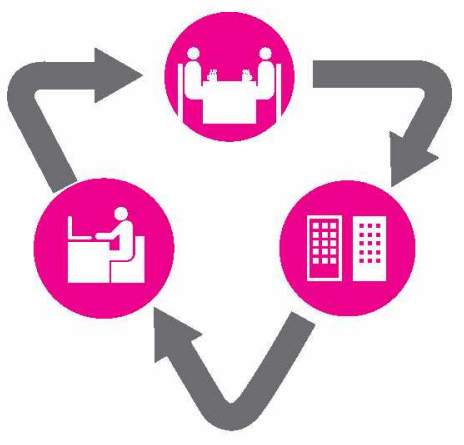

(1) CAFE

(II) DINING

(2iii) SHOPPINC

울: LIVING 


\section{GIFC}

GFA TOTAL GFA

7) FlOOR PLATE 2780 sqm



Plan

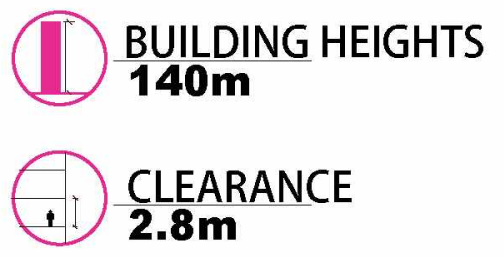

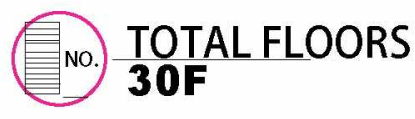

LEED STAN-
LEED SILVER

Section

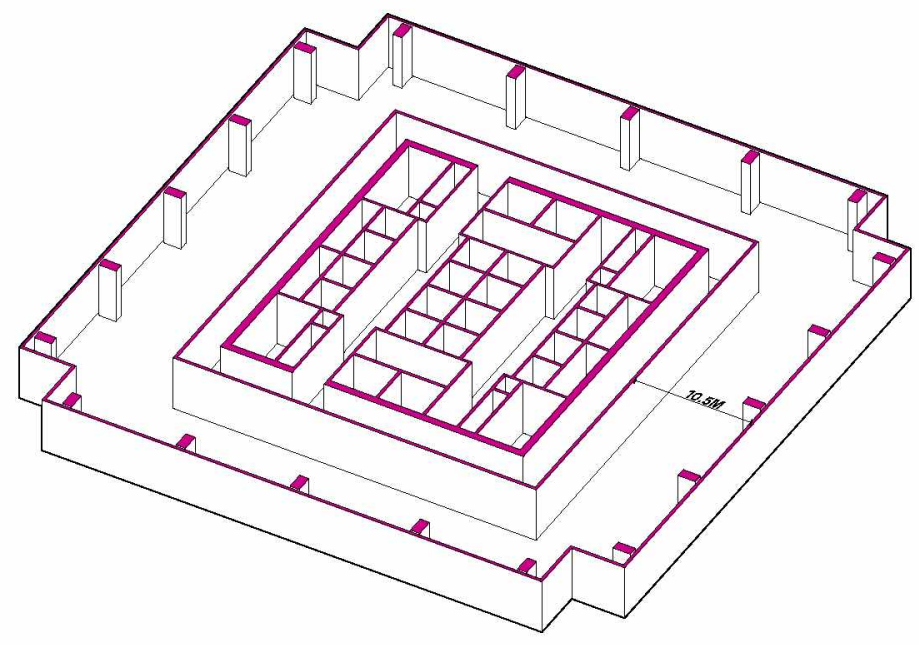

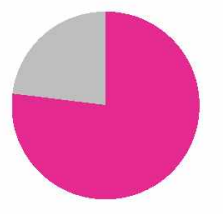

$77 \%$



$95 \%$

FLOOR EFFICIENCY OCCUPANCY

(P) PARKING LOTS

FIN FINISHED YEA 2012

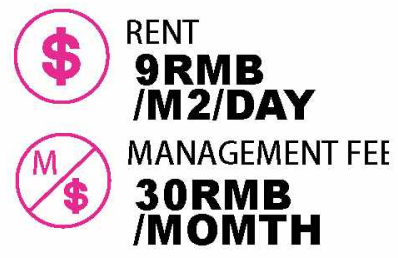






\section{DATA COMPARISON}

\section{GFA\&ELOOR PLATE}

TIPICAL FLOOR AREAnW

TOTOLGAMER

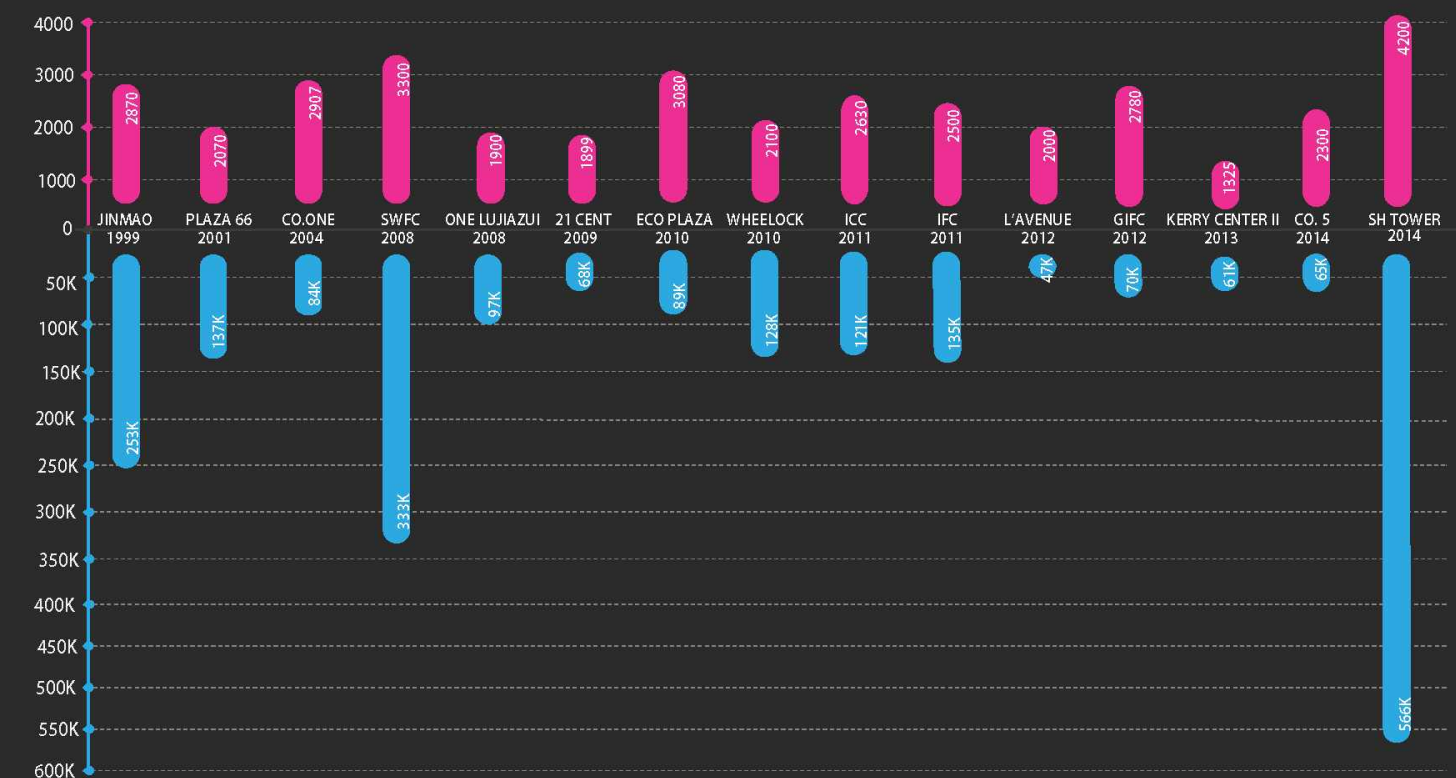

BUILDING HEIGHT\& CLEARENCE

HEIGHT/M

CELLING HEIGHT/m

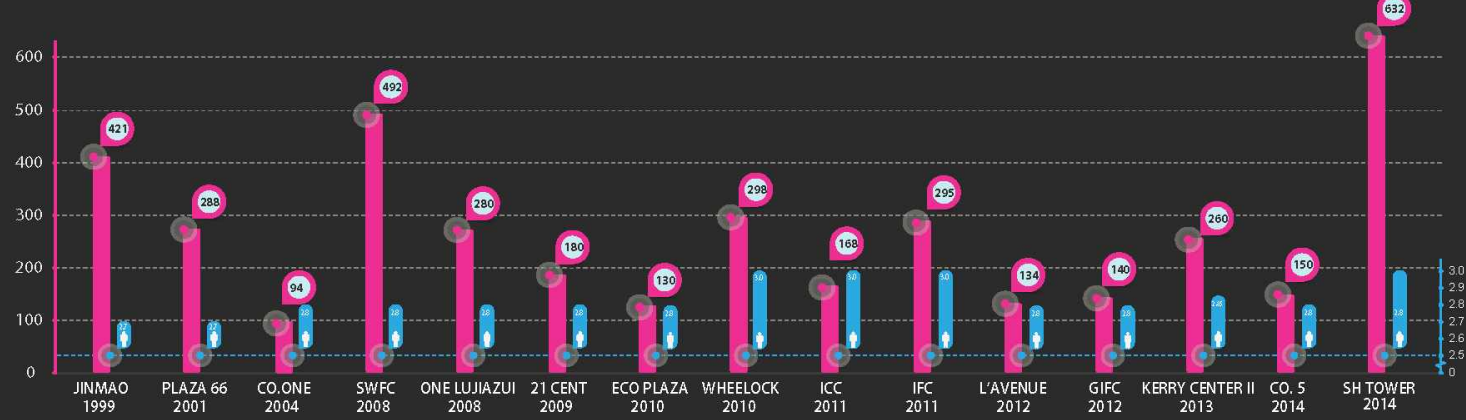




\section{FLOOREFFICIENCY}






\section{RENT\&EEES}

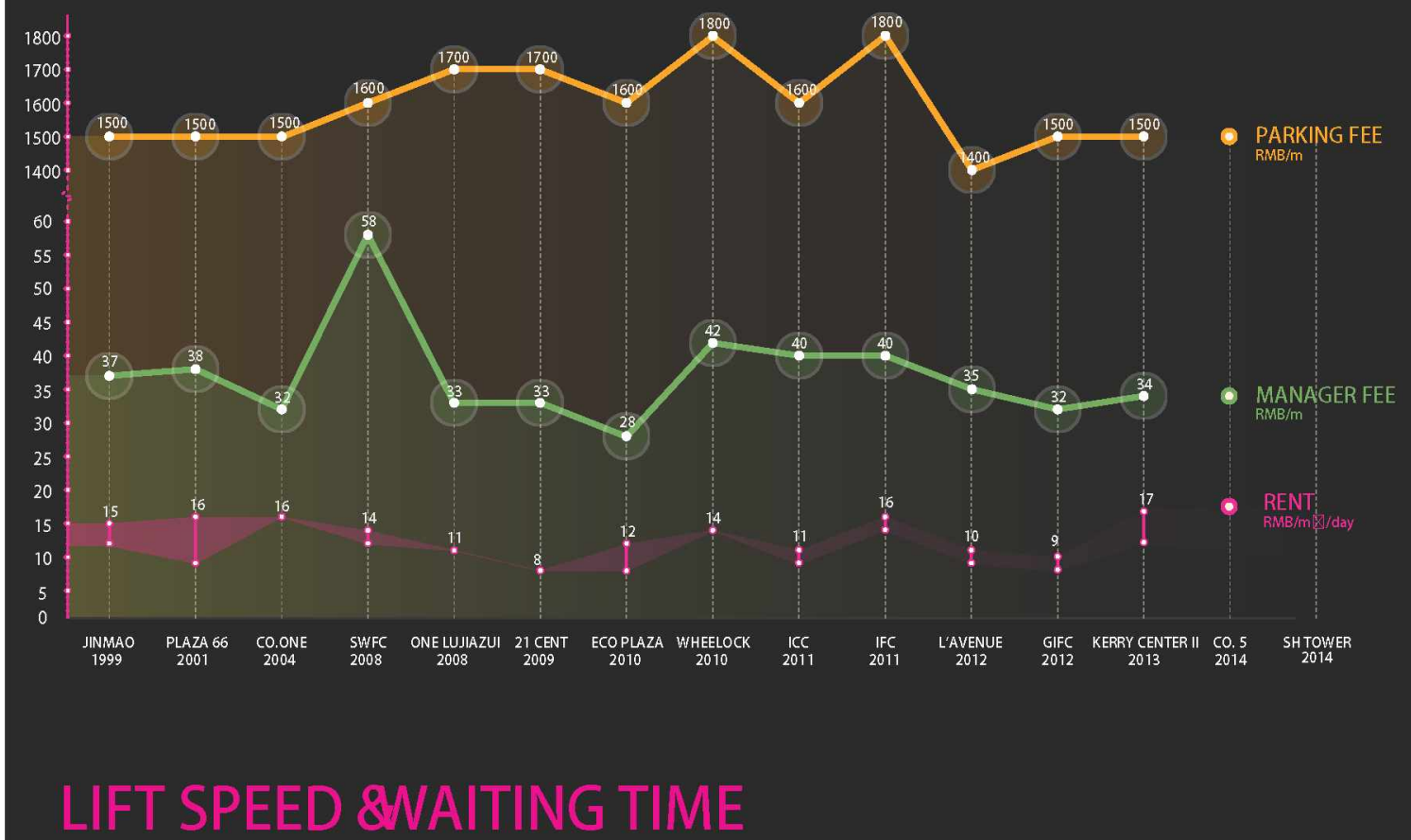

WAITING TIME/S

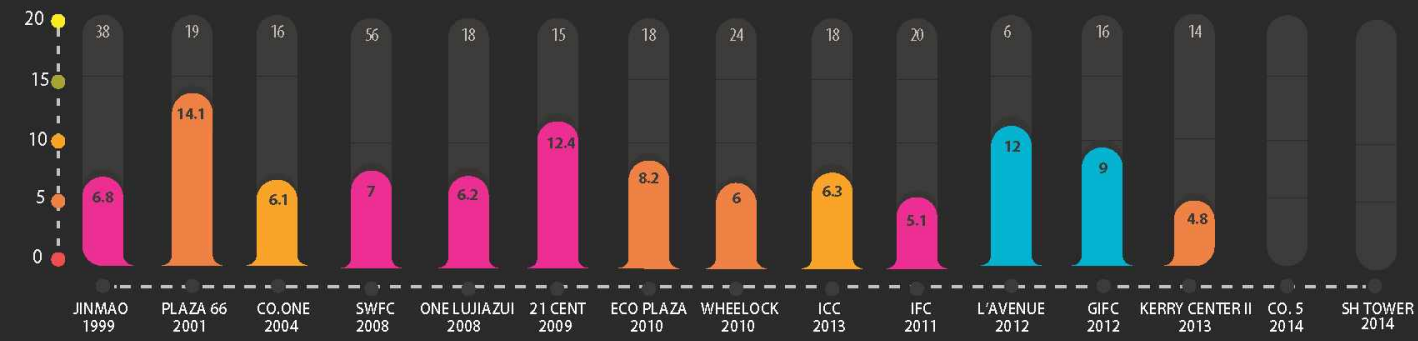

ELEVATOR SPEEDS/FLOOR

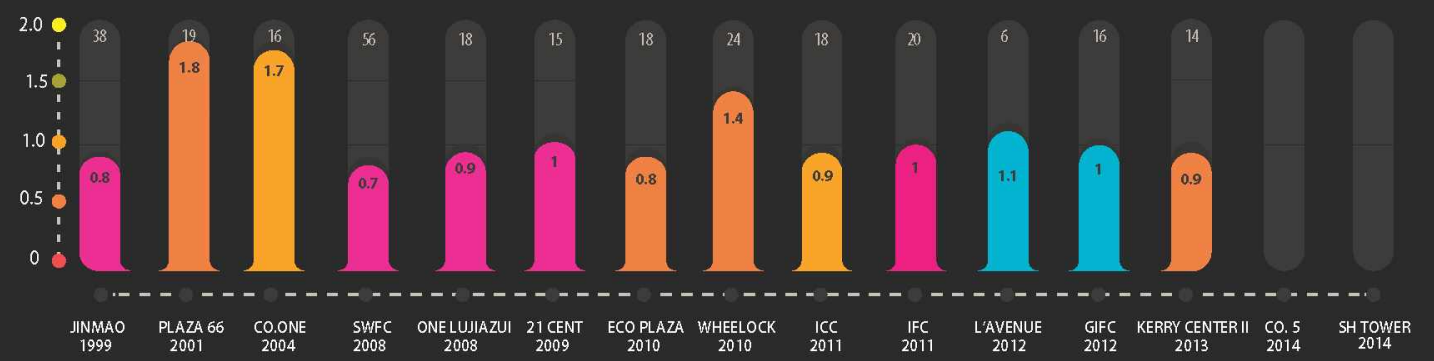




\section{LIST OF FIGURES}




\section{Chapter One}

Fig 1.1 "British Settlement in Shanghai" MPROJECT MUSE, Web. April 042014

https://muse.jhu.edu/login?auth=0\&type=summary\&url=/journals/twentiethcentury_china/ v034/34.2. kessler.html

Fig 1.2 "The Bund, 1928” GE GRAPHICUS, Web. April 052014

http://www.geographicus.com/P/AntiqueMap/ShanghaiBund-photo-1928

Fig 1.3 "The Suzhou Creek within the Urban Context, 1935" WIKIPEDIA, Web. April 032014

http://en.wikipedia.org/wikl/Shanghai_International_Settlement

Fig 1.4 "Factories along the Suzhou Creek" WIKIPEDIA, Web. April 032014

http://en.wikipedia.org/wikı/Shanghai_International_Settlement

Fig 1.5 Howe, Christopher. Shanghai, revolution and development in an Asian metropolis. Cambridge: Cambridge University Press, 1981. Print.

Fig 1.6 Alleyway House in Shanghai: Benjamin Gianni

Fig 1.7 "Typical Alleyway” RANDOMWIRE-EST, Web. April 022014

http://randomwire.com/shikumen-residences-in-shanghai/

Fig 1.8 "Demolition in Process, Shanghai" ChinaFile, Web. April 032014

https://www.chinafile.com/multimedia/photo-gallery/poor-accommodations

Fig 1.9 "Lujiazui 1990" Freshome, Web. March 242014

http://freshome.com/2011/01/28/then-and-now-staggering-20-year-transformation-of-lujiazui-districtshanghal/shanghai-china/

Fig 1.10 "Lujiazui 2010" Freshome, Web. March 242014

http://freshome.com/2011/01/28/then-and-now-staggering-20-year-transformation-of-lujiazui-districtshanghal/shanghai-china/ 


\section{Chapter Two}

Fig 2.1 Activated Time Study: Wenji Miao

Fig 2.2 "Jin Mao Tower" Wikipedia, Web. March 242014

http://sco.wikipedia.org/wiki/Jin_Mao_Touer

Fig 2.3 “Jin Mao Tower Section" Laura Jones Re Construction Management, Web. March 242014 http://laurajonesreae5317.blogspot.ca/

Fig 2.4 Shanghai Tower: Gensler, Shanghai office

Fig 2.5 Building Atrium: Gensler, Shanghai Office

Fig 2.6 Shanghai Tower Section: Gensler, Shanghai office

Fig 2.7 Shanghai 1933: Wenji Miao

Fig 2.8 Intertwining Bridges: Wenji Miao

Fig 2.9 Staff Stairway Encircling Core: wenji Miao

Fig 2.10 Cattle Walkway: Wenji Miao

Fig 2.11 Lattice Window Detail: Wenji Miao

Fig 2. 12 "Tianzifang" Panramio, Web. March 242014

http://www.panoramio.com/photo/81420011

Fig 2. 13 "Typical Shikumen Architecture" VANTAGE, Web. March 242014

http://www.vantageshanghai.com/en/scene/2013/04/shikumen-the-soul-of-shanghai.html

Fig 2. 14 Red Town Logo: Wenji Miao

Fig 2. 15 Interior Space 1: Wenji Miao

Fig 2. 16 Interior Space 2: Wenji Miao

Fig 2. 17 Red Town Gallery: Wenji Miao

Fig 2. 18 Art Sculpture in Red Town: Wenji Miao

Fig 2. 19 Red Town Central Green Space with Sculptures : Wenji Miao

Fig 2. 20 "Jianwai SOHO" MIMOA, Web. March 302014

http://www.mimoa.eu/projects/China/Beijing/Jianwai\%20SOHO

Fig 2. 21 "Site Circulation" Archinomy, Web. March 302014

http://www.archinomy.com/case-studies/1156/urban-design-jian-wai-soho-beijing

Fig 2. 22 "Land use Pattern” Archinomy, Web. March 302014

http://www.archinomy.com/case-studies/1156/urban-design-jian-wai-soho-beijing 
Fig 2. 23 "Building Orientation" Archinomy, Web. March 302014

http://www.archinomy.com/case-studies/1156/urban-design-jian-wai-soho-beijing

Fig 2. 24 "View of Jianwai SOHO" The Insight into Emptiness, Web. March 302014

http://chmak1.blogspot.ca/2008_07_01_archive.htmI

Fig 2.25 "Aerial View of Xintiandi" CINDYLUV ON THE LOOSE, Web. April 072014

http://lets-gogogo.blogspot.ca/2009/10/shanghai-6th-day-xin-tian-di-district.html

Fig 2.26 "Shikumen Buildings re-Purposed for Commercial Use" Buildings \& Lights, Web. April 072014 http://www.mushero.com/trips/asia/shanghai_05/buildings_lights.html

Fig 2.27 "Taipingqiao Park" Lost in Translation, Six Months in China, Web. April 072014

http://johndcain.wordpress.com/category/out-in-shanghal/ 


\section{Chapter three}

Fig 3.1 Location of Shanghai within China: Wenji Miao

Fig 3.2 Central Shanghai and Its Surroundings: Wenji Miao

Fig 3.3 In Relation to the Bund and the Huangpu River: Wenji Miao

Fig 3.4 Land Use Diagram: Wenji Miao

Fig 3.5 Looking North Up Zhongshan West Road on the Eastern Edge of the Site: Wenji Miao

Fig 3.6 The Suzhou Creek with the Site on the Right and Mid-Rise Housing Across the River to the Left: Wenji Miao

Fig 3.7 Low-Rise Buildings to the North of the Footbridge: Wenji Miao

Fig 3.8 Typical High-Rise Condo Apartments: Wenji Miao

Fig 3.9 The Zhongshan Park Subway Station: Wenji Miao

Fig 3.10 The Footbridge Across the Suzhou Creek at the Northwest Corner of the Site: Wenji Miao

Fig 3.11 Existing Site Circulation: Wenji Miao

Fig 3.12 Transportation: Wenji Miao

Fig 3.13 Amenities: Wenji Miao

Fig 3.14 Block Size Diagram: Wenji Miao

Fig 3.15 Bird's-Eye View of Site: Wenji Miao

Fig 3.16 The Elevated Walkway: Wenji Miao

Fig 3.17 Underneath the Walkway: Wenji Miao

Fig 3.18 Building 14: Wenji Miao

Fig 3.19 Pavilions Along the Elevated Walkway: Wenji Miao

Fig 3.20 Staircase Leading to the Elevated Walkway: Wenji Miao

Fig 3.21 Entrance to the Underground Parking Garage: Wenji Miao

Fig 3.22 Parking Garage Interior 1: Wenji Miao

Fig 3.23 Parking Garage Interior 2: Wenji Miao

Fig 3.24 Building Rating System: Wenji Miao

Fig 3.25 Building Inventory 1: Wenji Miao

Fig 3.26 Building Inventory 2: Wenji Miao 
Fig 3.27 Building Inventory 3: Wenji Miao

Fig 3.28 Building Inventory 4: Wenji Miao

Fig 3.29 Building Inventory 5: Wenji Miao

Fig 3.30 Design Approach Option 1: Wenji Miao

Fig 3.31 Design Approach Option 2: Wenji Miao

Fig 3.32 Design Approach Option 3: Wenji Miao

Fig 3.33 Design Approach Option 4: Wenji Miao

Fig 3.34 Design Approach Option 5: Wenji Miao

Fig 3.35 Design Approach Option 6: Wenji Miao

Fig 3.36 Existing buildings to be retained: Wenji Miao

Fig 3.37 Five Programs: Wenji Miao

Fig 3.38 Elevated Walkway / Tilted Planes: Wenji Miao

Fig 3.39 Vehicular Circulation: Wenji Miao

Fig 3.40 Grade-Level Pedestrian Circulation: Wenji Miao

Fig 3.41 Elevated Pedestrian Circulation: Wenji Miao

Fig 3.42 Sloped Housing Diagram: Wenji Miao

Fig 3.43 Sloped Housing Ground Level Plan: Wenji Miao

Fig 3.44 Sloped Housing Second Level Plan: Wenji Miao

Fig 3.45 Sloped Housing Section: Wenji Miao

Fig 3.46 Sloped Housing Overall Plan: Wenji Miao

Fig 3.47 Tilted Plane Atop Proposed Library: Wenji Miao

Fig 3.48 Bird's-Eye View 1: Wenji Miao

Fig 3.49 Bird's- Eye View 2: Wenji Miao

Fig 3.50 View of Proposed Office Towers and Building 14 from atop Library: Wenji Miao Fig 3.51 View of Live/Work Units and Elevated Walk-way, Looking South from One of the Residential Towers: Wenji Miao

Fig 3.52 Looking Through the Towers, Standing on the Elevated Walkway: Wenji Miao

Fig 3.53 Section Cut Through One of the Towers and the Underground Library: Wenji Miao 


\section{Conclusion}

Fig 4.1 Hotel on the Left, Under Construction: Wenji Miao

Fig 4.2 Building 1 Under Modification: Wenji Miao

Fig 4.3 Standing on the Elevated Walkway and Looking Towards to the Building 14 from North: Wenji Miao

Fig 4.4 Entrance to the Underground Parking, Now Incorporated with the Hotel: Wenji Miao

Fig 4.5 The East Part of the Building 14 is Under Excavation: Wenji Miao

* All Contents Listed in Appendix: Wenji Miao 


\section{BIBLIOGRAPHY}


Andrew Yang. March 42007 "A high-fashion lane in Shanghai" The New York Times March 32014 http://www.nytimes.com/2007/03/04/travel/04surfacing1.html?_r=0

Bracken, G.. The Shanghai alleyway house: a vanishing urban vernacular. London: Routledge, 2013. Print.

Cox, Wendell. "SHANGHAI: TORRID POPULATION GROWTH" April 172011 Newgeography April 022014 http://www.newgeography.com/content/002187-shanghai-torrid-population-growth

"Development Objectives" 2012 XINTIANDI STYLE April 042014

http://www.shanghaixintiandi.com/xintiandi/en/about_info.asp

"Gensler topes out China's tallest tower in Shanghai" August 3, 2013 The A to Z of Building February 182014

http://www.azobuild.com/news.aspx?news $/ D=17107$

Gensler. "SHANGHAI RISING" 2014 Gensler Design Update February 162014

http://du.gensler.com/vol5/shanghai-tower/\#/shanghai-rising

Howe, Christopher. Shanghai, revolution and development in an Asian metropolis. Cambridge: Cambridge University Press, 1981. Print, 233

"Jianwai SOHO" 2007. Beijing Real Estate March 052014

http://www.beijingrealestate.com/retail_sale_product_detail.asp?ProductID=669\&CategoryID=354

"Jin Mao" China Jin Mao Group CO., LTD February 102014

http://www.jinmao88.com/en/jinmao_edifice.htm

"Jin Mao Tower" 2013. Travel China Guide February 102014

http://www.travelchinaguide.com/attraction/shanghai/jinmao.htm

Johnson, Linda Cooke. Shanghai: from market town to treaty port, 1074-1858. Stanford, Calif.: Stanford University Press, 1995. Print.

Martin, Dylan “Shanghai's 1933 Slaughter house" 2014, Atlas Obscura February 32014

http://www.atlasobscura.com/places/1933-slaughterhouse

Mitsubishi Electric. "Mitsubishi Electric to Install World's Fastest Elevators in Shanghai Tower" 2014

Mitsubishi Electri Global February 162014 http://www.mitsubishielectric.com/news/2011/0928.html

Pott, F. L. Hawks. A short history of Shanghai, being an account of the growth and development of the international settlement. Shanghai [etc.: Kelly \& Walsh, 1928. Print.

Pridmore, Jay. Shanghai: the architecture of China's great urban center. New York: Abrams, 2008. Print.

"Red Town" 2011 City Weekend Shanghai February 162014

http://www.cityweekend.com.cn/shanghai/listings/travel/city-attractions/has/red-town/

"Shanghai Creative Industries Demonstration and Service Platform" 2010 CreativeCity March 12014 http://www.creativecity.sh.cn/en/

"Shanghai District Overview - Pudong" Knight Frank March 292014

http://www.knightfrank.com.cn/

"Shanghai Free Trade Zone Attracts 1,400 Companies" FINANCIAL TIMES March 292014

http://www.ft.com/cms/s/0/20b7714c-57fb-11e3-82fc-00144feabdc0.htm/\#axzz2nOYevep1

"Shanghai Tower" 2013 The Skyscraper Center February 182014

http://www.skyscrapercenter.com/shanghai/shanghai-tower/

"Shanghai Red Town Introduction" 2012. Legend February 222014

http://wenku.baidu.com/link? url=dgvQFjSCRNBjrTY9rRCsbu3h6RHZH4skSndJD9H17eScJRTsOjZR

q34gEEhI3IIKmTFg8XyuQPwPCOGEPd4BulThiRnfOMnoRhHTE3vC

Shao, Qin. Shanghai gone: domicide and defiance in a Chinese megacity. United Kingdom: Rowman \& Littlefield Publishers, Inc., 2013. Print. 
SOHO China "Company Profile" SOHO CHINA March 062014

http://www.sohochina.com/en/about

SOHO China "Jianwai SOHO" SOHO CHINA March 062014

http://jianwaisoho.sohochina.com/

"Taipingqiao Park, Xintiandi" October 212008 Gardenvisit. Com April 042014

http://www.gardenvisit.com/garden/taipingqiao_park_xintiandi

"The Jianwai SOHO" 2011 Baidu wenku March 052014

http://baike.baidu.com/view/230037.htm\#7

"The Jin Mao Tower" 2014 Baidu wenku February 162014

http://wenku.baidu.com/link?url=oYN5MP3Bb0G1Lc4XfUqJsbkX13RDMQ8dVCy34XzGBNapohvQIr_ rMe5CWQvnsDBVpbHUOKXYY1coS588ADKGqg8bmuwQcpwsHmzyp4ig_

"The Last Slaughterhouse on Earth: 1933 Shanghai” 2011, Lasasapark 2011 February 32014 http://www.lacasapark.com/la/2011/11/the-last-slaughterhouse-on-earth-1933-shanghai/

"Tianzifang" 2013. Travel China Guide March 62014

http://www.travelchinaguide.com/attraction/shanghai/tianzifang.htm

"Urban Design: Jianwai SOHO, Beijing" 2010. Archinomy March 052014

http://www.archinomy.com/case-studies/1156/urban-design-jian-wai-soho-beijing

Wright, Gwendolyn. Building the dream: a social history of housing in America. New York: Pantheon Books, 1981. Print.

Wu, Weiping, and Piper Rae Gaubatz. The Chinese city. Abingdon, Oxon: Routledge, 2013. Print, 166

Yang, Hongxu "Relocation and Demolishing in Shanghai" Sina Blog March 292014

http://blog.sina.com.cn/s/blog_48f7836101000k7x.html 